WANDERLEY DA COSTA

COMPORTAMENTO DAS FORÇAS DE ADESÃO DO ADESIVO SELANTE DE SILICONE E DO MASTIC BUTÍLICO SOB O EFEITO DA RADIAÇÃO IONIZANTE 
WANDERLEY DA COSTA

\section{COMPORTAMENTO DAS FORÇAS DE ADESÃO DO ADESIVO SELANTE DE SILICONE E DO MASTIC BUTÍLICO SOB O EFEITO DA RADIAÇÃO IONIZANTE}

Tese apresentada como parte dos requisitos para obtenção do grau de Doutor em Engenharia.

São Paulo 


\section{COMPORTAMENTO DAS FORÇAS DE ADESÃO DO ADESIVO SELANTE DE SILICONE E DO MASTIC BUTÍLICO SOB O EFEITO DA RADIAÇÃO IONIZANTE}

Tese apresentada como parte dos requisitos para obtenção do grau de Doutor em Engenharia.

Área de concentração:

Engenharia de Metalúrgica e de Materiais.

Orientador: Prof. Dr. Hélio Wiebeck

São Paulo 
Este exemplar foi revisado e alterado em relação à versão original, sob responsabilidade única do autor e com a anuência de seu orientador.

São Paulo, 09 de fevereiro de 2012.

Assinatura do autor

Assinatura do orientador

Costa, Wanderley da

Comportamento das forças de adesão do adesivo selante de silicone e do mastic butílico sob o efeito da radiação ionizante / W. da Costa. -- ed.rev. -- São Paulo, 2012. $93 \mathrm{p}$.

Tese (Doutorado) - Escola Politécnica da Universidade de São Paulo. Departamento de Engenharia Metalúrgica e de Materiais.

1. Silicone 2. Adesivos 3. Selantes 4. Radiação ionizante I. Universidade de São Paulo. Escola Politécnica. Departamento de Engenharia Metalúrgica e de Materiais II. t. 


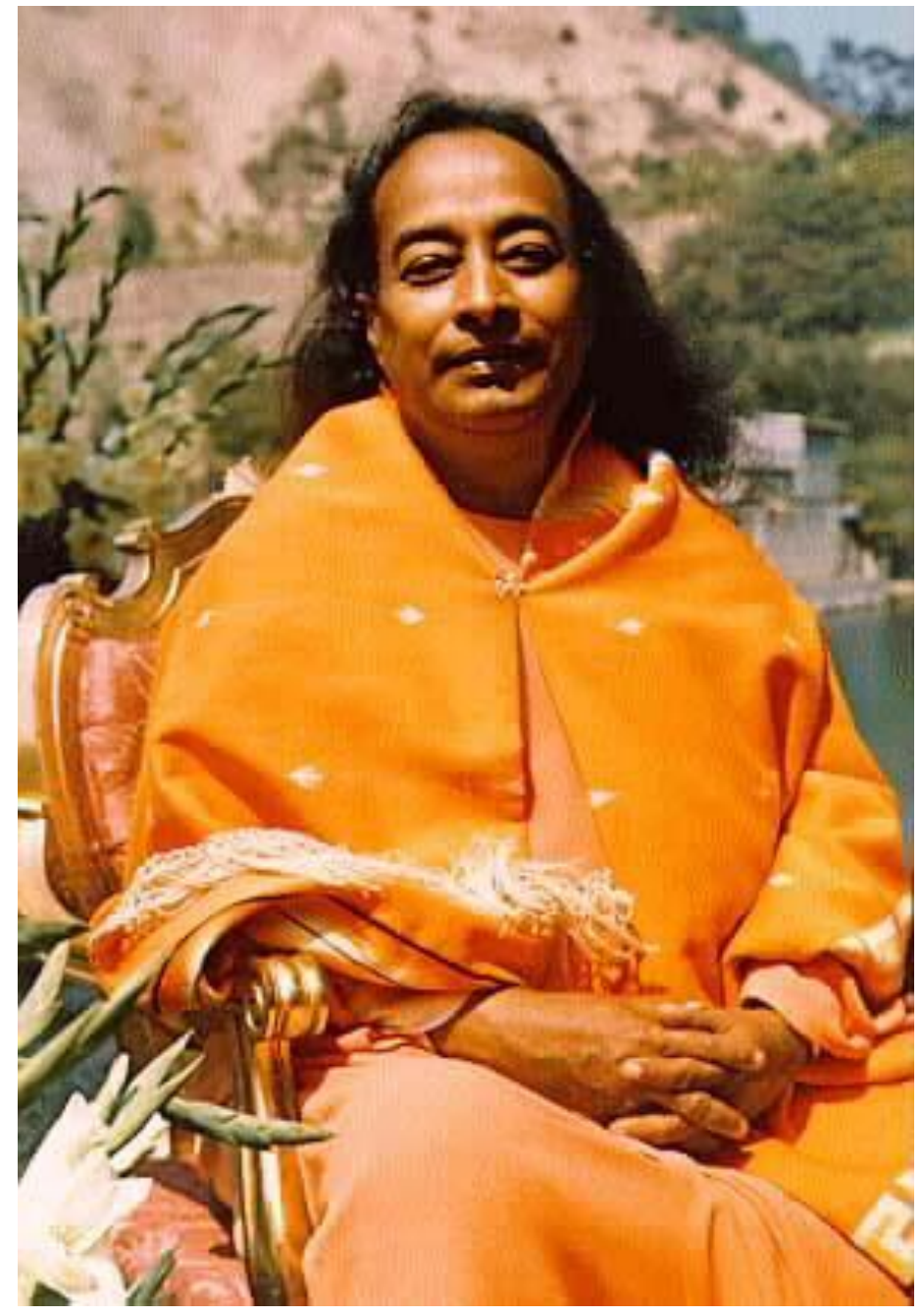

Dedico este trabalho ao grande mestre Paramahansa Yogananda, que me ensinou que eu devo enfrentar a batalha da vida com a coragem de um herói e um sorriso de conquistador, vivendo como um príncipe de paz, sentado no trono da tranquilidade, dirigindo o reino das atividades. 


\section{AGRADECIMENTOS}

Acima de tudo ao nosso Pai Celestial, e aos meus Gurus por todas as dádivas que tive na vida.

Aos meus pais João e Filomena, aos meus padrinhos Nicomédio e Aurora por me tornarem a pessoa que sou.

À minha esposa Silvana pelo amor e paciência incondicional.

Aos meus anjos da guarda: William e Adriely.

Aos meus mestres Paramahansa Yogananda e Swami Sri Yukteswar Giri pela sabedoria transmitida durante toda minha vida.

Em especial ao Prof. Dr. Hélio Wiebeck pela confiança, paciência, sabedoria e orientação deste trabalho.

Ao Prof. Dr. José Roberto Martinelli pelo apoio nas discussões dos artigos científicos sobre o tema.

À Professora MSc. Edith Marie Malateaux de Souza pela valiosa ajuda nas discussões sobre o tema.

A toda diretoria da empresa BRASCOLA LTDA pela valiosa colaboração e confiança neste trabalho e pela disponibilidade do laboratório de Pesquisa e Desenvolvimento e na liberação de relatórios internos sobre o tema. A equipe de químicos pela ajuda nos ensaios físicos, em especial ao químico pesquisador Edson Garcia Blanco pela colaboração na discussão dos resultados dos ensaios.

Ao Professor Dr. Leonardo A.G, Silva e ao Centro de Tecnologia das RadiaçõesIPEN pela colaboração na irradiação dos corpos de prova, e nos ensaios de grau de reticulação. 


\section{RESUMO}

Os adesivos são produtos capazes de manter materiais unidos, mediante ligações entre as superfícies. Selantes são produtos capazes de manter preenchido um espaço entre duas superfícies, por meio de uma barreira que se configura como uma "ponte" entre as duas superfícies. O mastic é um produto obtido por uma mistura de substâncias tendo como principal polímero o butil, com consistência de uma massa não secativa que pode ser utilizada como selante. Os polisiloxanos, também conhecidos como silicones são os mais importantes polímeros sintéticos com estrutura inorgânica, e são matrizes dos adesivos selantes de silicone. Para comprovar como o comportamento das forças de adesão destes produtos acontece, foram utilizadas cinco técnicas diferenciadas. Estes produtos foram submetidos a duas condições distintas para verificar o comportamento da adesão, um em condições ambiente e outro sob influência de radiação ionizante. Os resultados obtidos demonstraram não só a diferença entre produtos (silicone e mastic), mas também que as forças de adesão têm comportamentos diferentes nas condições às quais foram submetidas às amostras. Com isto atingi-se o objetivo desse estudo que é apresentar a diferenciação entre o mastic e o silicone, muitas vezes considerados como um só produto denominado mastic. Desta forma comprovase que:

1. o silicone pode ser considerado um adesivo selante em condições ambientes

2. o mastic melhora consideravelmente sua adesão, quando submetido à radição ionizante, e esta característica de adesão pode ser uma excelente alternativa para o mercado de adesivos.

Palavras-chave: adesivo, selantes, adesivo selantes de silcone e mastic 


\section{ABSTRACT}

Adhesives are products that can keep materials together by bonds between the surfaces. Sealants are products that can keep filled a space between two surfaces, through a barrier that is configured as a "bridge" between the two surfaces. The mastic is a product made of a mixture of substances with the primary butyl polymer, with the consistency of a mass not dried that can be used as a sealant. The polysiloxane, also known as silicone are the most important synthetic polymers with inorganic structure, and are matrices of silicone adhesive sealants. To demonstrate the behavior of the adhesive forces of these products under different conditions, we used five different techniques. These products were subjected to two different conditions to verify the behavior of adhesion, one at the environmental condition and another under the ionizing radiation. The results showed not only differences between products (silicone and mastic), but also that the adhesive forces have different behaviors under the conditions which the samples were subjected. With this was reached the goal of this study that aspired show the differences between the mastic and silicone, this last one is often considered - erroneously - the same as mastic. Thus it was proven that:

1. silicone can be regarded as an adhesive and a sealant at ambient conditions,

2. mastic improves substantially adhesion in an environment of ionizing radiation and this property can be an excellent alternative to the adhesive market.

Keywords: adhesive, sealants, silicone adhesive sealants and mastic 


\section{SUMÁRIO}

AGRADECIMENTOS

RESUMO

ABSTRACT

LISTA DE FIGURAS

LISTA DE TABELAS

1 INTRODUÇÃO

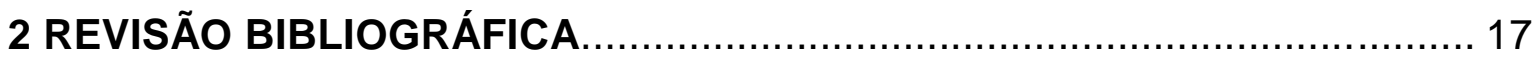

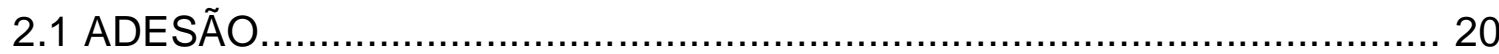

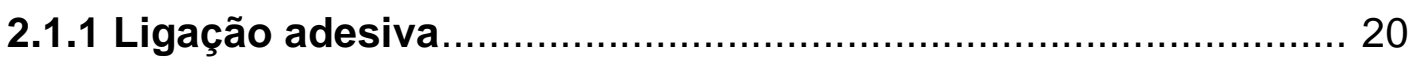

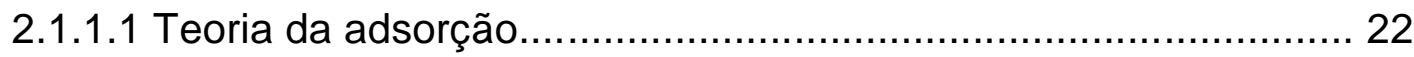

2.1.1.2 Teoria mecânica................................................................. 23

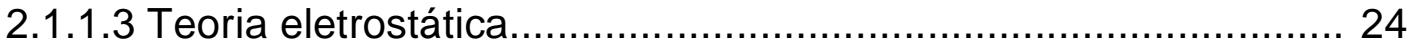

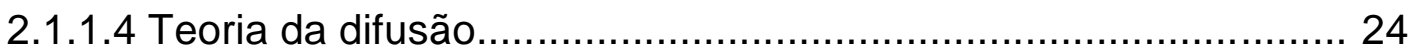

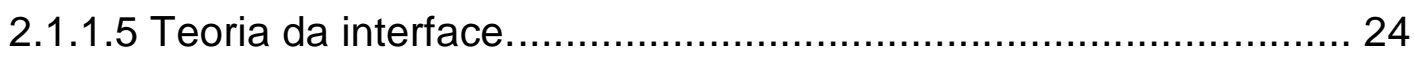

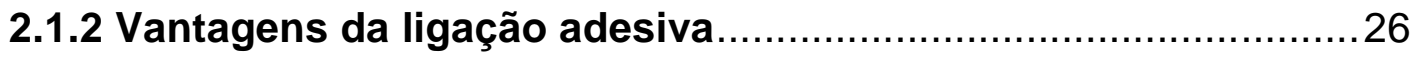

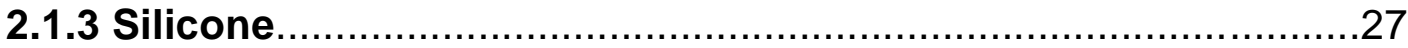

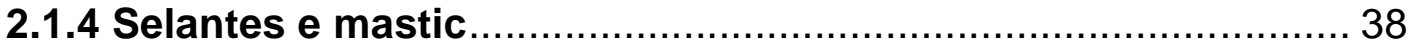

2.1.5 Recomendações para durabilidade da colagem....................... 43

2.1.6 Propriedades mecânicas do silicone e do mastic...................... 44

2.1.7 Propriedades elásticas do silicone e do mastic........................ 44

2.1.8 Funcionalidade de um produto .................................................. 46

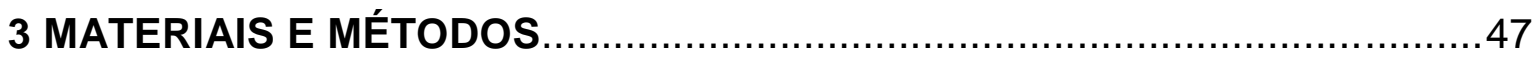

3.1 ENSAIO DE ALONGAMENTO E RUPTURA................................... 48

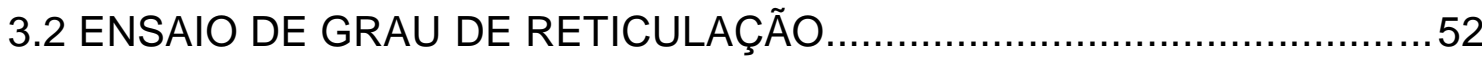


3.3 ENSAIO DE CALORIMETRIA EXPLORATÓRIA DIFERENCIAL

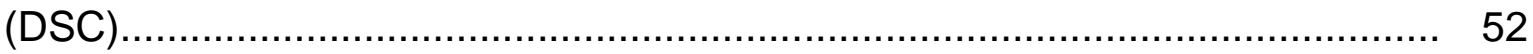

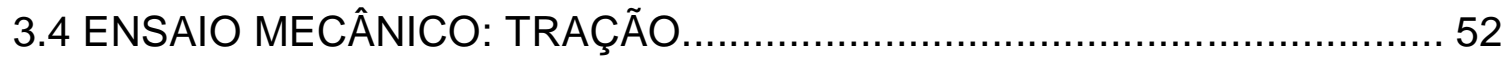

3.5 ESPECTROSCOPIA INFRAVERMELHA POR TRANSFORMADA DE FOURIER (FTIR) ...................................................................... 58

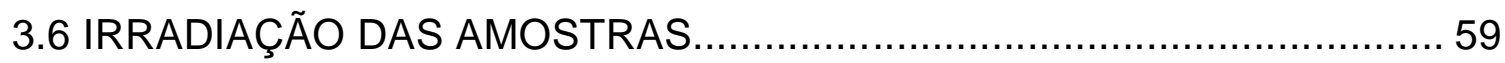

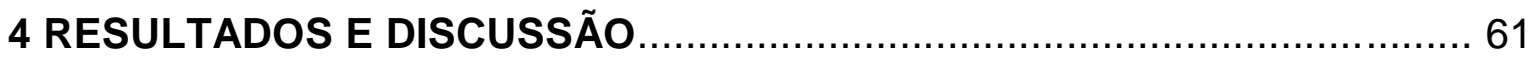

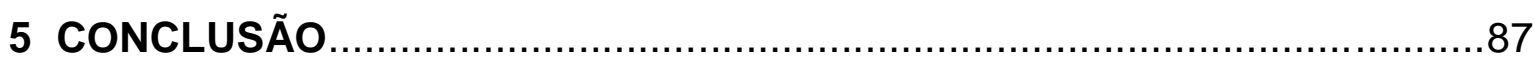

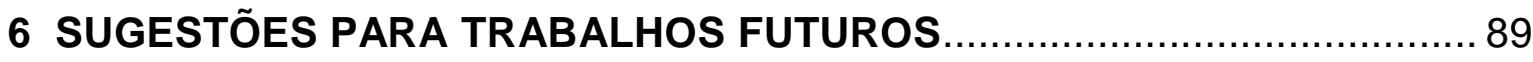

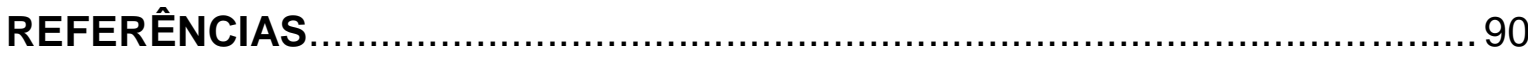




\section{LISTA DE FIGURAS}

Figura 1 - Energia de superfície do substrato............................................. 19

Figura 2 - Adesão e coesão.............................................................. 22

Figura 3 - Estrutura inorgânica e inorgânica-orgânica do silício, (a) SiO e (b)

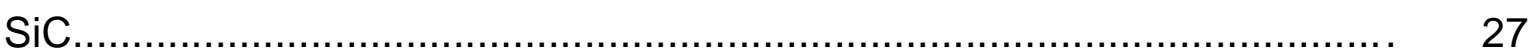

Figura 4 - Reações para obtenção do polímero silicone.............................. 29

Figura 5 - Principal estrutura do polímero de silicone................................ 29

Figura 6 - Reação de oxidação do silicone............................................... 31

Figura 7 - Mecanismo do processo de cura do adesivo selante de silicone - mono componente.............................................................................. 33

Figura 8 - Mecanismo de adesão do selante de silicone no vidro.................. 34

Figura 9 - Exemplo de formulação adesivo selante de silicone de baixo

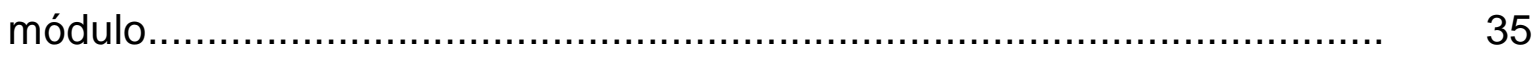

Figura 10 - Colagens de vidros com adesivo selante de silicone................ 37

Figura 11 - Ensaios Mecânico: Tração (11A); (11B)................................. 47

Figura 12 - Manta de silicone, após 28 dias da aplicação.......................... 49

Figura 13 - Corpos de prova silicone, após 28 dias da aplicação preparados conforme a norma ASTM D 412....................................................... 49

Figura 14 - Corpos de prova silicone no ensaio de alongamento até a ruptura

Figura 15 - Manta de mastic, após 28 dias da aplicação.......................... 50

Figura 16 - Manta de mastic, após 28 dias da aplicação, sem condições para o ensaio de ruptura

Figura 17 - Manta de mastic, após 28 dias de sua aplicação não apresenta a cura do material

Figura 18 - Preparação dos corpos de prova mastic, retirando excesso de material

Figura 19 - Preparação dos corpos de prova mastic, ajustando no gabarito

Figura 20 - Preparação dos corpos de prova silicone, aplicando o material.

Figura 21 - Preparação dos corpos de prova silicone, ajustando no gabarito 
Figura 22 - Corpo de prova mastic sendo tracionado

Figura 23 - Corpo de prova mastic sendo tracionado, até a descolagem do material.

Figura 24 - Corpo de prova silicone sendo tracionado

Figura 25 - Corpo de prova silicone tracionado até a descolagem do material.

Figura 26 - Corpos de prova (cilindros) mastic e silicone, após 28 dias de aplicação

Figura 27 - Curva DSC da amostra de silicone sem radiação ionizante......

Figura 28 - Curva DSC da amostra de silicone com radiação de 5kGy.......

Figura 29 - Curva DSC da amostra de silicone com radiação de 10kGy.....

Figura 30 - Curva DSC da amostra de silicone com radiação de 20kGy..... 66

Figura 31 - Curva DSC da amostra de silicone com radiação de 30kGy.....

Figura 32 - Curva DSC da amostra de mastic sem radiação ionizante.

Figura 33 - Curva DSC da amostra de mastic com radiação de 5kGy........ 69

Figura 34 - Curva DSC da amostra de mastic com radiação de 10kGy....... 70

Figura 35 - Curva DSC da amostra de mastic com radiação de 20kGy....... 71

Figura 36 - Curva DSC da amostra de mastic com radiação de 30kGy.......

Figura 37 - Tensão de cisalhamanto do silicone sem radiação nos ciclos de 7, 14

e 28 dias após aplicação

Figura 38 - Tensão de cisalhamanto do mastic sem radiação nos ciclos de 7, 14 e 28 dias após aplicação.

Figura 39 - Tensão de cisalhamento do silicone com doses de radiação após 28 dias de cura.

Figura 40 - Tração de cisalhamento do mastic com radiação após 28 dias de cura. 76

Figura 41 - Tensão de cisalhamanto em função da radiação, amostra 1 ..... 77

Figura 42 - Tensão de cisalhamanto em função da radiação, amostra 2.....

Figura 43 - Tensão de cisalhamanto em função da radiação, amostra 3.....

Figura 44 - Tensão de cisalhamanto em função da radiação, amostra 4.....

Figura 45 - Tensão de cisalhamanto em função da radiação, amostra 5.....

Figura 46 - Tensão de cisalhamanto em função da radiação, amostra 6.....

Figura 47 - Tensão de cisalhamanto em função da radiação, amostra 7.....

Figura 48 - Tensão de cisalhamanto em função da radiação, amostra 8..... 
Figura 49 - Tensão de cisalhamanto em função da radiação, amostra 9.... 81

Figura 50 - Tensão de cisalhamanto em função da radiação, amostra 10.. 81

Figura 51 - Estrutura do polímero butil............................................... 83

Figura 52 - Espectros de FTIR do silicone antes e após irradiação com feixe de elétrons 30 kGy................................................................. 84

Figura 53 - Espectros de FTIR do mastic antes e após irradiação com feixe de

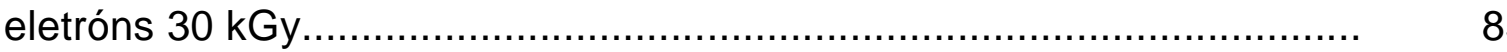




\section{LISTA DE TABELAS}

Tabela 1 - Classificação dos vários mecanismos de adesão.................... 17

Tabela 2 - Principais substâncias que compõe a matriz dos silicones...... $\quad 30$

Tabela 3 - Exemplos de formulações de mastic....................................... 39

Tabela 4 - Caracteristicas dos selantes butil (mastic) e silicone.................. 43

Tabela 5 - Ensaios de alongamanto e resistência à tração na ruptura do

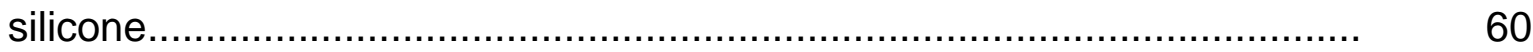

Tabela 6 - Resultados dos ensaios de gel do mastic e silicone.................... 61

Tabela 7 - Tensão de cisalhamento silicone sem radiação ionizante em função do

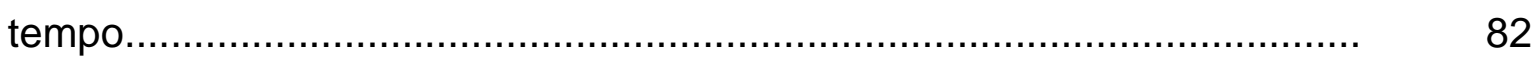

Tabela 8 - Tensão de cisalhamento mastic sem radiação ionizante em função do tempo .............................................................................. 82

Tabela 9 - Tensão de cisalhamento silicone com radiação ionizante em função da

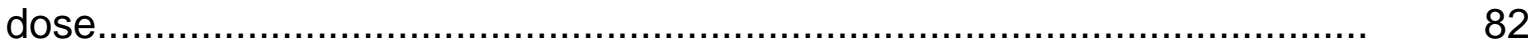

Tabela 10 -Tensão de cisalhamento mastic com radiação ionizante em função da dose 


\section{INTRODUÇÃO}

Evidências arqueológicas indicam que os adesivos têm sido usados por mais de 6.000 anos e que muitos objetos que podem ser vistos em museus ainda estão colados com adesivos até por mais de 3.000 anos. Mesmo que não se necessite de um extremo de confiabilidade e durabilidade, ainda assim deseja-se que $\mathrm{o}$ adesivo dure mais do que o dispositivo em que for aplicado. $\mathrm{A}$ arte de formular, que se desenvolveu por volta de 1950, consistia basicamente em se utilizar certos polímeros naturais como meio de "colar" um determinado material em outro. Utilizou-se cola de origem animal, material asfáltico, resina de árvores entre outros materiais, tudo isso muito antes da introdução das técnicas modernas, baseadas no emprego de amido vegetal ou polímeros sintéticos.

O adesivo é um produto obtido por meio de uma mistura de substâncias capaz de unir materiais por meio de um processo de cura ou cristalização, mediante ligações químicas na superfície. Ter uma consistência adequada para sua aplicação seja manual ou automatizada.

O selante é um produto obtido por meio de uma mistura de substâncias capaz de selar e vedar uma fenda em diversos materiais podendo colar ou não. Sendo capaz de manter pelo menos preenchido um espaço entre duas superfícies, formando assim uma "ponte" entre elas, tanto física como química.

O mastic é um produto obtido por uma mistura de substâncias, com uma consistência de uma massa não secativa que pode ser utilizada como selante, na área de adesivos estes selantes são formulados principalmente com as borrachas butílicas.

Percebe-se que na prática existe uma dificuldade de diferenciação entre adesivo, selante e mastic, esta falta de exatidão nas definições e escassez de publicação leva a necessidade de um aprofundamento mais detalhado sobre 0 tema.

Tanto os adesivos como os selantes apresentam adesão. Um fenômeno complexo em que os materiais são unidos por meio de uma "colagem" está relacionada com as tensões entre o adesivo e o material (substrato) e as interações nas superfícies.

Com o passar do tempo, desenvolveram-se vários adesivos que apresentavam propriedades idênticas (senão melhores), transformando a antiga 
arte numa técnica aprimorada de aplicação. Hoje em dia, vários fatores contam na escolha de um determinado tipo de adesivo:

1. Os adesivos devem ser compatíveis com a superfície em que serão aplicados;

2. Se esta superfície for impermeável, e não absorvente, os adesivos deverão estar livres de água ou solventes orgânicos;

3. Deverão ter baixo custo;

4. Os adesivos não deverão ser mais rígidos que o material onde serão aplicados, para que as tensões não se concentrem nos adesivos;

5. Após endurecerem, a junta colada deverá estar apta a resistir às condições ambientes.

O endurecimento de alguns adesivos pode ser efetuado dos seguintes modos:

a. Resfriamento de um "sólido" fundido - Esse processo já era utilizado na Roma antiga para a confecção de barcos, sendo o betume o adesivo em questão. Por exemplo, cera de parafina reforçada com polietileno, é usada para o revestimento de papéis que necessitam pouca permeabilidade à umidade. Os diácidos comercialmente importantes nesse caso são dímeros ou trímeros de ácidos graxos insaturados, que se unem por meio das insaturações. Já os grupos amida dos polímeros assim obtidos dão boa adesão ao papel, couro, metais e borracha, e as cadeias alifáticas dão flexibilidade ao adesivo.

b. Técnica de evaporação do solvente - A adição de um solvente ao adesivo visa principalmente a redução de sua viscosidade. Assim, a água é usada para dissolver amido, dextrinas, cola de proteínas, silicato de sódio, poliacetato de vinila (PVA), etc. No caso de adesivos formulados com borracha natural ou regenerada, policloropreno, borracha nítrica, nitrocelulose e alguns polímeros vinílicos, utilizam-se solventes orgânicos. O uso consiste na aplicação de emulsão do adesivo em seu solvente na superfície a ser colada, faz-se pressão e, quando o solvente evaporar, a colagem estará feita.

Esta técnica é empregada em fitas gomadas, etiquetas, etc., sendo os constituintes mais usados no preparo destes adesivos contendo 
polímeros citados anteriormente, uma resina aglutinante (politerpeno), antioxidantes, plastificantes (como o óleo mineral e a lanolina) e carga, como óxido de zinco, óxido de magnésio e óxido de alumínio tri hidratado.

c. Polimerização no local - Nesse caso é obtida pela formação de ligações cruzadas entre elas. Pertencem a este grupo todas as resinas termorrígidas, como a resina uréia-formol (conhecida como baquelite), melanina-formol, a borracha de silicone, poliuretanos, etc. Os adesivos desse grupo possuem a vantagem, principalmente depois de curados, de apresentar grande estabilidade dimensional, resistência a elevadas temperaturas e a solventes, em comparação com os demais adesivos.

O mercado brasileiro de adesivo, com base nos dados estatísticos da ABIQUIM (Associação Brasileira das Indústrias Químicas) no ano de 2010, movimentou vendas da ordem de 374.191 toneladas de produtos que corresponde a um faturamento de aproximadamente $R \$ 2,38$ bilhões de reais. Os selantes representam 65.871 toneladas deste mercado, que correspondem aproximadamente a $\mathrm{R} \$ 457$ milhões de reais.

Portanto, este trabalho tem por finalidade realizar uma investigação prática, diferenciando os selantes de silicone e os de mastic, em função do comportamento das tensões de cisalhamento, com e sem radiação ionizante. 


\section{REVISÃO BIBLIOGRÁFICA}

$\mathrm{Na}$ revisão bibliográfica vamos esplanar os conceitos básicos utilizados nos adesivos e selantes.

Lee e Orlowski (1973) definiram o termo adesivo como uma substância capaz de unir materiais pelo envolvimento de suas superfícies. A adesão é um estado em que duas superfícies estão unidas por forças interfaciais que poderiam ser de valência primária ou secundária, químicas ou mecânicas, apresentados na Tabela 1. Os adesivos são compostos por substâncias inorgânicas e orgânicas.

Tabela 1 - Classificação dos vários mecanismos de adesão dos selantes

\begin{tabular}{|c|c|c|c|}
\hline \multirow[b]{2}{*}{ União } & \multirow{2}{*}{$\begin{array}{l}\text { Adesão } \\
\text { mecânica }\end{array}$} & Efeitos geométricos & $\begin{array}{l}\text { rugosidade, porosidade, } \\
\text { retenções microscópicas }\end{array}$ \\
\hline & & Efeito reológico & estresse e contração \\
\hline \multirow[b]{2}{*}{ Adesiva } & $\begin{array}{l}\text { Adesão } \\
\text { química }\end{array}$ & $\begin{array}{c}\text { Forças de } \\
\text { valência } \\
\text { primária }\end{array}$ & $\begin{array}{c}\text { união iônica } \\
\text { união covalente } \\
\text { união metálica }\end{array}$ \\
\hline & Específica & $\begin{array}{l}\text { Forças de } \\
\text { valências } \\
\text { secundárias }\end{array}$ & $\begin{array}{c}\text { interação bi-polar } \\
\text { forças de Van der Waals } \\
\text { pontes de hidrogênio }\end{array}$ \\
\hline
\end{tabular}

Fonte: Adaptado da tese - Coutinho (2000)

Conforme a norma ABNT NBR 9239:2011 o termo adesivo é substância ou matéria capaz de manter materiais unidos, mediante ligações de superfície.

Petrie (2007) define selante como uma substância capaz de manter pelo menos preenchido um espaço entre duas superfícies, mantendo uma barreira e tornando-se como uma "ponte" entre as duas superfícies.

Os adesivos e selantes são denominações muitas vezes consideradas em conjunto porque ambos realizam o mesmo trabalho de colar e selar, e devem atender tanto as especificações de engenharia quanto as ambientais.

Os principais conceitos de uma ligação adesiva são: adesivo; adesão e aderentes. 
A adesão pode ser definida adesão como sendo a atração molecular exercida entre as superfícies de contato dos materiais ou a atração de moléculas em uma interface. As forças moleculares atrativas que envolvem a adesão foram divididas em físicas e químicas. As forças físicas incluíam as forças de Van der Waals, ligações de hidrogênio e interação bipolar. As forças químicas resultaram das formações de ligações covalentes, iônicas e metálicas e são consideradas mais resistentes que as forças de união física (Coutinho, 2000).

Para estabelecer a adesão, o adesivo ou selante deve preencher em função de sua massa e viscosidade a maior área possível, levando em consideração o relevo da superfície do material onde ocorrerá a adesão entre os materiais (Buonocore, 1963). A molhabilidade é um conceito, muito importante para os adesivos e selantes, que traduz a capacidade de um líquido molhar um sólido e estabelece que a tensão crítica de superfície do sólido deve no mínimo ser igual numericamente a tensão superficial do líquido (Fox, 1950). Essa característica de molhamento é fundamental entre as moléculas do adesivo e do aderente (material também chamado de substrato). Quando as forças atrativas entre as moléculas do adesivo ou selante e do substrato são intensas, pode-se dizer que houve o molhamento, isto é, adesão. Esse fenômeno estava associado à existência de pequeno ângulo de contato, próximo de $0^{\circ}$. Isso significa um excelente espalhamento do adesivo ou selante sobre a superfície do substrato.

Thelen (1966) define adesão como sendo a força de união nas superfícies de contato de dois materiais. As forças físicas de atração e absorção, descritas juntamente como forças de Van der Waals, têm maior significado na adesão. A amplitude dessas forças intermoleculares é consideravelmente mais baixa se 0 material adesivo não entrar em contato profundo com os locais de adesão devido à rugosidade relativa das superfícies tratadas mecanicamente. Esta é a razão pela qual o adesivo ou selante deve penetrar diretamente dentro da rugosidade da superfície completando a todos os espaços da mesma. Desta maneira, a resistência da força do adesivo ou selante depende da penetração do mesmo na superfície (para atingir a mais completa troca intermolecular). Em determinada tensão da superfície do adesivo, a molhabilidade depende da energia da superfície do substrato e da viscosidade do adesivo. A molhabilidade 
também pode ser reduzida, se substâncias contaminantes estiverem presentes na superfície do material. Uma consideração importante é a relação entre a energia de superfície do adesivo e o material. Ambos constituem uma função direta do ângulo de contato, como demostrado na Figura 1 (Fleischmann, 1997).
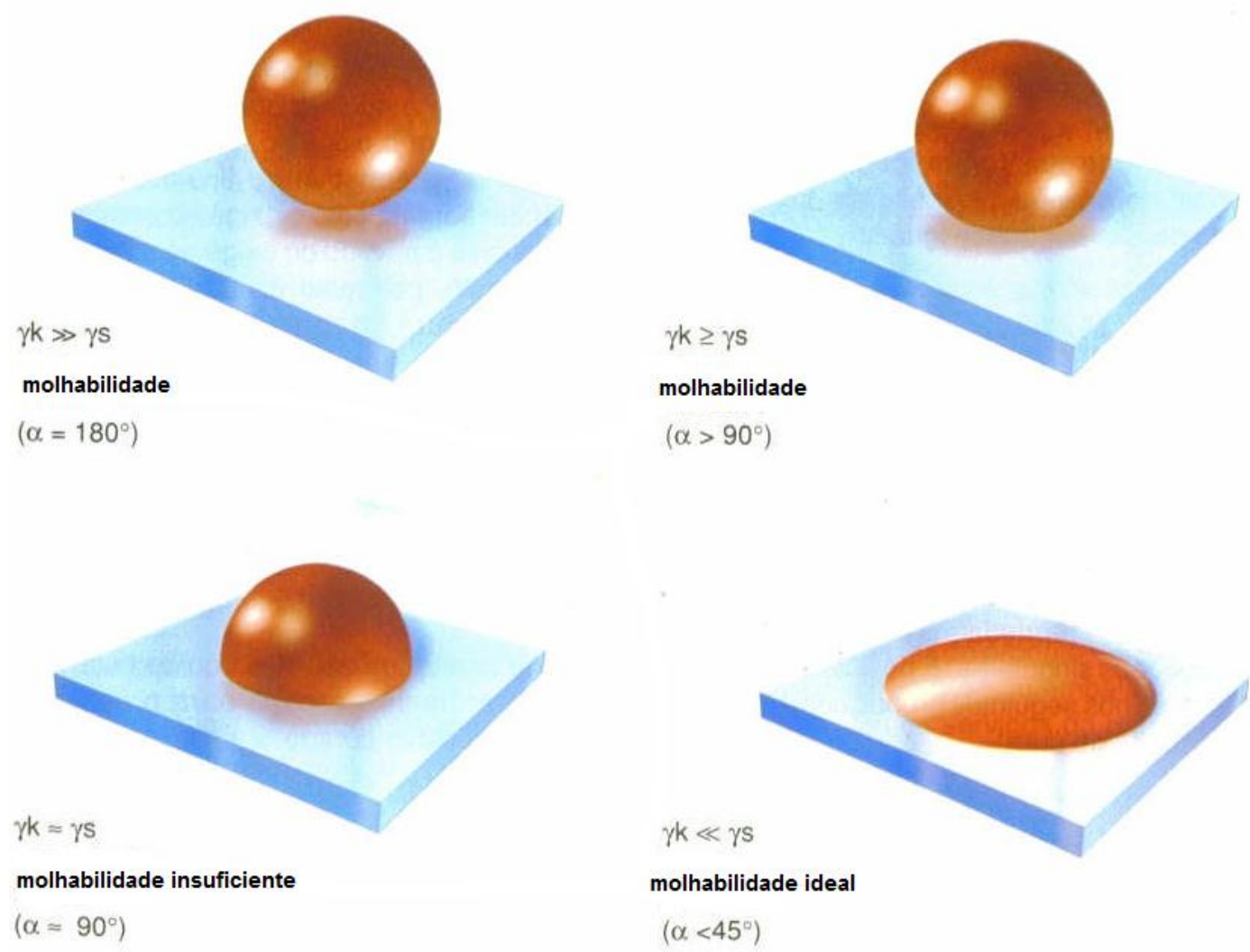

$\left(\alpha>90^{\circ}\right)$

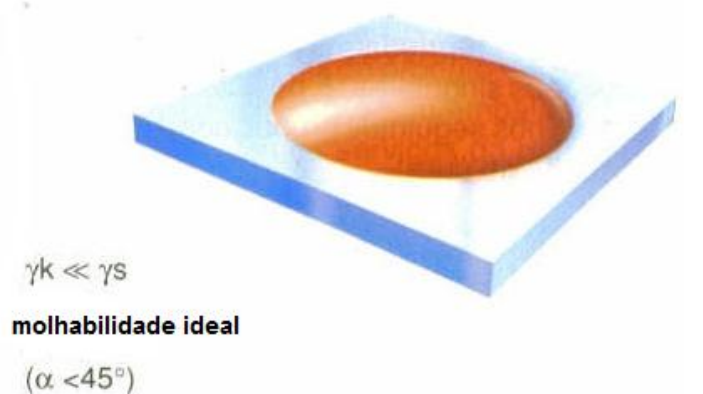

Figura 1 - Energia de superfície do substrato

Fonte: Adaptado do livro - Loctaite (Fleischmann, 1997)

As forças secundárias ou forças de Van der Waals são as principais forças que deveriam atuar quando se projeta um adesivo. Existem dois critérios para se obter alta adesão: 1 - o adesivo deveria primeiro apresentar uma boa molhabilidade na superfície do substrato; 2 - o adesivo deveria mudar da fase líquida para sólida, com mínima contração. As moléculas do adesivo deveriam entrar em contato íntimo com as moléculas do substrato. Quando se deseja uma adesão mecânica, é necessário que o adesivo seja capaz de escoar nos orifícios, poros ou fendas microscópicas. Assim, independente do tipo de mecanismo de adesão, para se alcançar uma adesão ótima dever-se-ia primeiro possuir uma superfície limpa. Fleischmann (1997) alerta que a presença de impurezas não permite uma adesão forte, pois impedem a atuação das forças 
de Van der Waals; em segundo lugar, necessitou-se de um adesivo com viscosidade bastante baixa para que pudesse escoar sobre a superfície e microretenções e, por último, que houvesse uma "compatibilidade" química entre o adesivo e a superfície de tal modo que as moléculas das duas substâncias realmente entrassem em contato. Entretanto as forças localizadas na superfície tenderam a inclinar-se em direção às moléculas adjacentes, ao invés de projetarem-se no espaço. O resultado foi uma intensificação ou concentração visível de forças na superfície do material.

\subsection{ADESÃO}

A adesão é um fenômeno complexo tem envolvido esforços distintos em síntese de polímeros, química de superfícies e ainda da mecânica teórica experimental. A superfície na adesão é um dos passos mais importantes e sabese que a resistência das ligações está intimamente ligada à afinidade do adesivo com a superfície de contato. Em função destas considerações é de suma importância conhecer alguns conceitos sobre adesivos.

O conhecimento do processo de aplicação de adesivos é essencial para uma adesão bem sucedida. As causas mais frequentes de falha nas adesões não envolvem resistência do adesivo, e sim a preparação inadequada dos substratos e a seleção imprópria do adesivo.

\subsection{1 - Ligação adesiva}

As forças envolvidas na interação entre adesivo e substrato são as mesmas que estão presentes no interior do adesivo, isto é, são forças que estão atreladas a formulação e interação com as matérias primas que compõe o mesmo. Para compreender o que ocorre com um adesivo, é necessário primeiro conhecer as forças que mantém as moléculas do adesivo unidas entre si, não só ocorre com os adesivos de baixa viscosidade como também com os selantes (Quini, 2011).

As forças adesivas e coesivas podem ser classificadas como primárias e secundárias. Forças primárias são subdivididas em forças covalentes, iônicas e metálicas. As forças covalentes são aquelas formadas por ligações covalentes, 
que apresentam energia de ligação entre 60 e $700 \mathrm{~kJ} \cdot \mathrm{mol}^{-1}$, como por exemplo aquelas encontradas em polímeros orgânicos ramificados. As ligações iônicas, de

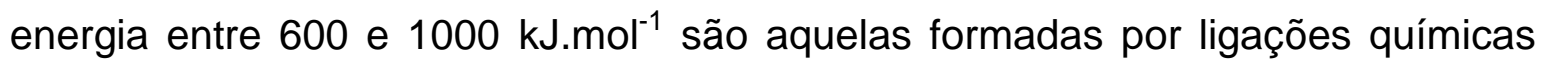
iônicas como as presentes em cristais inorgânicos. As forças metálicas, de energia entre 100 e $350 \mathrm{~kJ} \mathrm{~mol}^{-1}$ correspondem às forças presentes entre os átomos de uma liga metálica (Petrie, 2007).

Existem três tipos de forças secundárias, também chamadas de forças de Van der Waals: o dipolo induzido, dipolo permanente e ligações de hidrogênio são importantes tanto quanto as primárias (Payne, 1964). As forças do tipo dipolo induzido, são também conhecidas como forças de London, têm energia de ligação entre 0,1 e $40 \mathrm{~kJ} \mathrm{~mol}^{-1}$ e as de dipolo permanente, têm energia entre 4 e 20 $\mathrm{kJ} . \mathrm{mol}^{-1}$ e estão presentes entre moléculas polares. Quando em uma molécula existem elementos muito eletronegativos, por exemplo, flúor, oxigênio e nitrogênio, ligados a átomos de hidrogênio, a eletronegatividade destes átomos exerce uma maior atração do par eletrônico desta ligação polarizando a molécula, consequentemente esta molécula ao aproximar-se de outra que tenha elementos eletronegativos irá interagir com o hidrogênio formando uma ligação chamada de ligação de hidrogênio, que apresenta energia em torno de $40 \mathrm{~kJ} \cdot \mathrm{mol}^{-1}$.

Destaca-se que as forças primárias não estão presentes na maioria dos adesivos sendo, entretanto, uma necessidade nos adesivos de alto desempenho, também denominados de estruturais (epóxi e metacrilatos). Para a maioria dos adesivos, as forças mais importantes relativas à adesão são as forças secundárias. A exata natureza destas forças e sua influência na resistência adesiva e coesiva são difíceis de determinar com precisão em razão de sua complexidade que está atrelada com a formulação do adesivo (Quini, 2011).

As forças de interação entre o adesivo e o substrato podem ser medidas com a mensuração do trabalho necessário para ocorrer uma separação das duas superfícies, que pode ser entre o adesivo e substrato, ou para que haja uma separação entre as moléculas de um material sólido. Esta força é dependente das forças intermoleculares que existem no material e sobre o espaço intermolecular, sendo às vezes chamada de energia de superfície.

O mecanismo de adesão para adesivos como para selantes que corresponde à união entre o adesivo e o substrato, ainda não foi totalmente esclarecido. Muitas teorias foram formuladas, mas nenhuma delas foi capaz de 
esclarecer completamente o fenômeno. Algumas são mais adequadas a certos substratos e aplicações, outras são mais apropriadas a diferentes circunstâncias. Cada teoria tem sido assunto de estudos, questionamento e controvérsias. No entanto, cada uma delas emprega conceitos e informações que são aplicáveis na compreensão dos requisitos básicos de uma boa ligação entre adesivo e substrato (Ahagon, Gent, 1975).

Os componetes das formulações tanto de adesivos como de selantes são pontes entre as superfícies dos substratos, quer sejam dos mesmos materiais ou diferentes. O mecanismo de adesão e coesão é demonstrado na Figura 2. A adesão seja do adesivo ou selante está diretamente relacionada com a superfície, enquanto que a coesão está atrelada às forças entre os componentes da formulação, a resultante de ambas é o resultado da colagem.

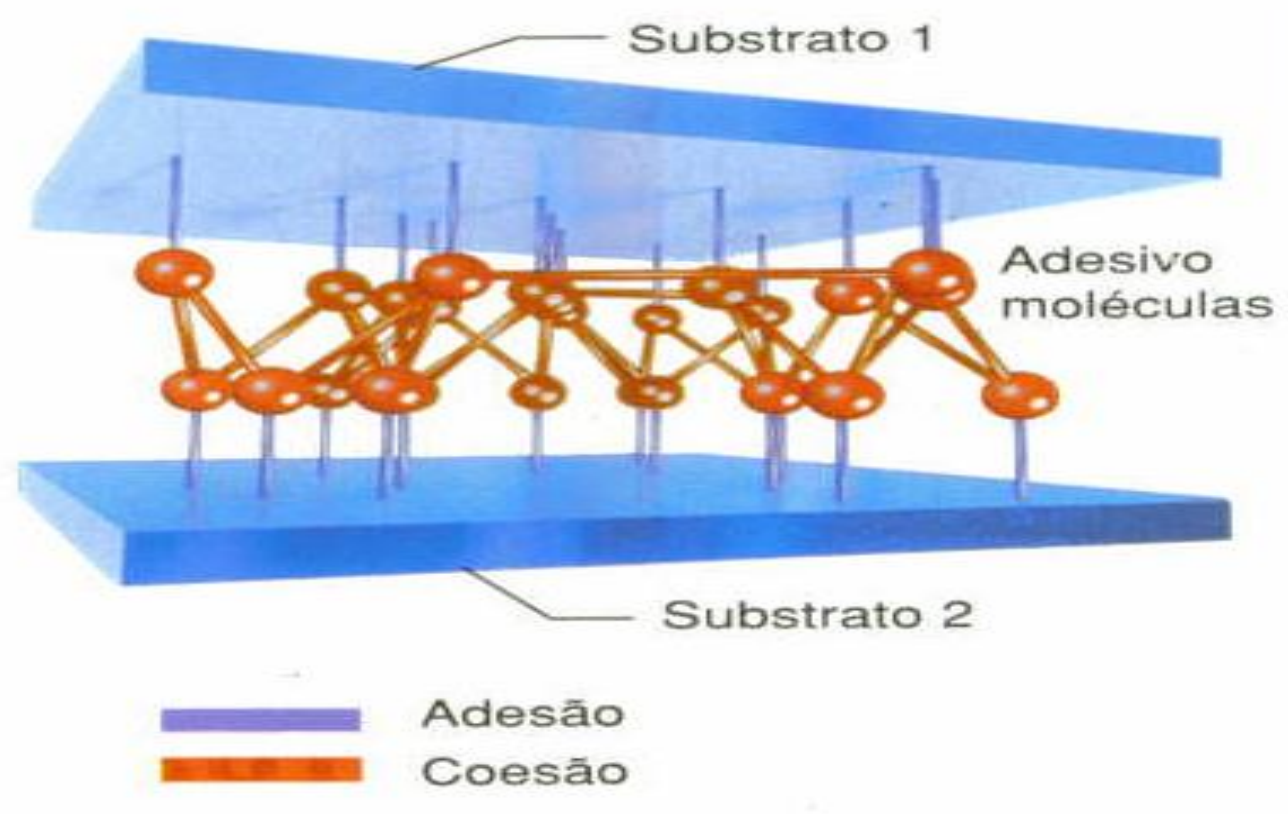

Figura 2 - Adesão e coesão

Fonte: Adaptado do livro Loctaite (Fleischmann, 1997)

\subsubsection{1 - Teoria da adsorção}

A teoria da adsorção estabelece que a adesão seja o resultado do contato molecular entre dois materiais e as forças de atração se desenvolvem na superfície. A adesão resulta da adsorção de moléculas do adesivo pelo substrato e as forças secundárias de Van der Waals passam a atuar. Para estas forças se desenvolverem nas respectivas superfícies não devem estar separadas mais do 
que 50 nanômetros de distância. Portanto, o adesivo deve ter um contato molecular muito próximo com a superfície do substrato. Para que este contato ocorra é preciso que haja uma boa molhabilidade. Esta molhabilidade ocorre quando o adesivo consegue fluir entre as irregularidades existentes na superfície do substrato, preenchendo desta forma os vales da superfície. Quando isto não ocorre pode haver o acúmulo de minúsculas bolhas de ar ao longo da interface dando origem a regiões vazias enfraquecendo a colagem (Schneberger, 1970).

A molhabilidade é favorecida quando a energia de superfície do substrato é alta e a tensão superficial do líquido é baixa. Polímeros de baixa energia superficial molham facilmente substratos de alta energia, como por exemplo, metais. De forma inversa, substratos poliméricos de baixa energia são de difícil molhabilidade, como por exemplo: polietileno, polipropileno e polímeros fluorados (Quini, 2011).

\subsubsection{Teoria mecânica}

A superfície de um material sólido nunca é totalmente lisa, mas consiste de uma combinação de picos e vales. Logo, é desejável que o adesivo seja capaz de preencher estas micro cavidades expulsando o ar presente no interior das mesmas.

Uma das formas de aumentar a adesão, considerando a rugosidade superficial, é pelo acréscimo da área total de contato entre adesivo e substrato. Outra forma é que após o preenchimento das cavidades o adesivo formará uma ancoragem mecânica com o substrato.

Há muitos casos onde as forças de adesão resultam de um trabalho conjunto na junta, Nestes casos, a resistência apresentada pela junta será uma soma da adesão ocorrida em razão das interações primárias e secundárias, com o efeito da ancoragem mecânica ocorrido.

A ancoragem mecânica do adesivo parece ser o fator primordial no processo de colagem de substratos porosos. Frequentemente a ligação entre 0 adesivo e o substrato não poroso melhora após o substrato receber um tratamento abrasivo. O efeito benéfico da rugosidade na superfície ocorre em razão da ancoragem mecânica, formação de uma superfície mais limpa, formação 
de uma superfície mais reativa e aumento da área de contato, o sentido do aumento da área é importante, e sua profundidade (Pocius, 1997).

\subsubsection{Teoria eletrostática}

Embora haja aplicações em que a eletrostática seja considerada, esta teoria não tem sido aplicada tanto quanto as teorias de adsorção e mecânica. A teoria eletrostática propõe que forças eletrostáticas ocorrem na forma de uma interface entre o adesivo e substrato, atuando como uma resistência à separação. Esta teoria pôde ser confirmada pela ocorrência de descargas elétricas quando um adesivo é submetido ao ensaio carga de descascamento (Fleischmann, 1997), também conhecida como tensão de despelamento do substrato.

\subsubsection{Teoria da difusão}

O conceito fundamental da teoria da difusão é que o adesivo atua por interdifusão de moléculas do adesivo com o substrato. Ela é aplicável primordialmente quando ambos os materiais, adesivo e substrato, são de origem polimérica, possuem compatibilidade quanto à polaridade. Nos substratos termoplásticos a difusão ocorre por ação do solvente presente no adesivo ou por calor no caso dos termofusíveis conhecidos como hotmelts. Outra possibilidade de difusão para termoplásticos é quando o substrato e adesivo são solúveis um no outro, porém isto é relativamente raro. Desta forma, a teoria da difusão pode ser aplicada apenas em um número limitado de casos. É importante lembrar que existe uma técnica que é chamada de interdifusão a frio na qual existe uma abertura na superfície do substrato realizada pelo solvente, onde a matéria-prima sólida, do adesivo, é a mesma que constitui o substrato, consequentemente quando o solvente evaporar ocorre à função dos substratos (Voyutzkii, 1963).

\subsubsection{Teoria da camada de interface}

Quando uma falha ocorre em uma junta próximo à interface do adesivo e substrato, usualmente é chamada de falha coesiva, esta falha pode originar-se como consequência da ruptura de uma fina camada de baixa resistência na 
região da interface. Esta teoria sugere que esta camada fraca pode formar-se em razão do adesivo, substrato, ambiente ou uma combinação destas três, a qual pode ocorrer como decorrência de impurezas concentradas próximo à superfície da colagem, como por exemplo, desmoldantes, graxas, óleos, poeira e migração de plastificantes. Por esta razão é importante sempre limpar a superfície antes da aplicação do adesivo ou selante.

Alguns substratos metálicos contém na sua superfície uma camada de óxidos metálicos, como óxido de alumínio, que formam uma camada muito resistente e não comprometem a resistência da junta, dependendo da especificação de engenharia em relação à colagem pode ser um fator que eleva as forças de adesão do mesmo. No entanto óxidos de cobre presentes em algumas ligas de cobre formam uma camada fraca e necessitam ser removidos antes da aplicação do adesivo.

Durante o período de cura do adesivo também pode ocorrer a formação de uma camada fraca na interface, como a que ocorre, por exemplo, em algumas superfícies metálicas em que a presença de titânio pode reagir com certos endurecedores (poliamida), muito comum nas colagens com adesivo base epóxi. Por fim, durante a exposição do adesivo às condições de uso, uma camada fraca na interface também pode surgir em razão de difusão de umidade ou outro líquido que possa ter contato com a junta. Plastificantes, solventes ou outros componentes de baixa massa molar também podem migrar de dentro do corpo do adesivo ou do substrato para a interface prejudicando a resistência da junta (Bikerman, 1961).

De acordo com Skeist (1977), os adesivos podem ser entendidos como sendo uma substância com propriedade de aderir fortemente a um substrato, mantendo vários substratos de um mesmo material ou materiais diferentes unidos por meio da força de adesão.

A adesão é um dos fenômenos mais importantes para a compreensão da formação da ligação adesiva que pode ser entendida como a interação entre duas superfícies, causada por um forte campo de forças atrativas, provenientes dos constituintes de cada superfície. 


\subsection{2 - Vantagens da ligação adesiva}

A estabilidade de uma estrutura adesiva depende em grande parte da resistência, rigidez e durabilidade das ligações.

Algumas vantagens de se utilizar os adesivos:

- A distribuição de esforços em áreas mais amplas torna possível a obtenção de ligações mais simples com menor resistência às tensões de cisalhamento. Evita-se assim o uso de materiais de junção mecânica, muitas vezes uma inadequada estética, deixando rugosidade ou ressaltos na superfície;

- A linha adesiva pode ser uma barreira contra a umidade, impermeabilizando frestas ou fissuras;

- Sua execução pode ser mais rápida e econômica;

- Há a possibilidade de se melhorar a relação força/peso e a estabilidade dimensional dos materiais anisotrópicos por meio de peças cruzadas, por exemplo, na madeira compensada;

- Os adesivos permitem a união de materiais não semelhantes, aumentando ainda mais o seu campo de aplicação;

- Fibras, pequenas partículas e filmes pouco espessos que não puderam ser aproveitados por qualquer outra técnica podem ser agrupados com o uso de adesivos.

A resistência da ligação formada entre o sólido e o adesivo, depende de uma combinação complexa de forças de atração entre os materiais e uma série de fatores secundários que tendem a reduzir a eficiência da mesma. As forças de coesão e adesão resultam de forças de ligação primária (eletrostáticas, covalentes ou metálicas) ou secundária (Van der Waals), fazem parte da combinação das forças de atração. Entre os fatores que reconhecidamente reduzem a eficiência de uma ligação estão as imperfeições de contato, presença de contaminações na superfície e a concentração de tensões em consequência das condições impostas externamente ou das mudanças internas na interface resultante da cura do adesivo (Quini, 2011). 


\subsection{3 - Silicone}

O principal componente dos silicones é o silício: o segundo elemento mais abundante da superfície da Terra, depois do oxigênio. A reação do silicone foi descoberta pelo químico Johann Berzelius (1779-1848) na tentativa de sintetizar e reagir outros compostos com o silício. $\mathrm{O}$ uso do silício requer processamentos químicos muito complexos, que só começaram a ser desenvolvidos por volta de 1930 na Europa, precisamente em setembro de 1938, a descoberta dos silicones foi uma contribuição muito importante não só na área de adesivos, tintas, impermeabilizantes; principalmente na de eletrônica com a evolução dos computadores no vale do silício nos Estados Unidos da América. Para os cientistas o mais importante foi tentar uma polimerização com um composto inorgânico, transformando-o de Si-O-Si Figura 3 (a) para Si-C Figura 3 (b), isto é, introduzindo compostos orgânicos como, por exemplo, radicais metila $\left(-\mathrm{CH}_{3}\right)$ em uma estrutura inorgânica como a do silício (Liebhafsky, 1978), como mostrado na Figura 3.

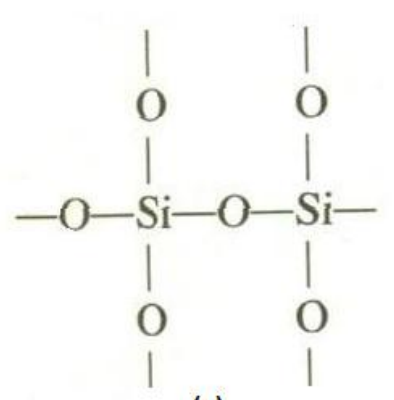

(a)

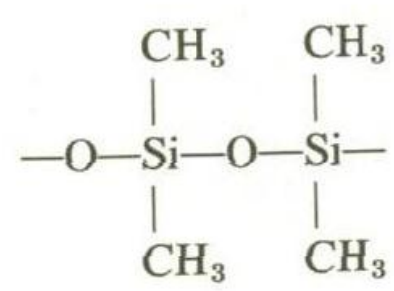

(b)

Figura 3: Estrutura inorgânica e inorgânica-orgânica do silício, (a) Si-O e (b) SiC. Fonte: Adaptado do livro - (Bodnar, 1966)

A tecnologia dos adesivos do silicone, principalmente no enfoque analítico na busca de soluções alternativas, é ao mesmo tempo ciência e arte. Desde a segunda guerra mundial, desenvolvem-se muitas substâncias para a fabricação de óleos impermeabilizantes, tintas, adesivos, revestimentos, espumas rígidas e flexíveis, entre outros produtos. A partir de 1940 a indústria do silicone dos EUA passou a ter importância, com produção em larga escala industrial destes adesivos. 
Em razão da grande variedade de materiais que se pode obter, este foi o ramo na área de polímeros que mais se desenvolveu nas últimas décadas. Uma área de interesse na química do silício, além da eletrônica, é a de adesivos, em que se tentam resolver problemas específicos quanto à adesão de substratos, principalmente dos metais e plásticos de engenharia. Com suas excelentes propriedades de adesão, vedação, resistência a intempéries e química dos silicones conquistaram mercados importantes como, por exemplo: construção civil, eletrônica, espacial e até mesmo militar.

Bodnar (1966) demonstrou o mecanismo da reação de como é feita a cura do silicone mono componente. Embora estes produtos sejam formulados para aplicações de selagem e recobrimento (tintas), eles são incluídos aqui porque um selante é essencialmente um adesivo que além de aderir em superfícies também pode ser utilizado para preenchimento de grandes espaços vazios, com uma viscosidade elevada. Mesmo agregando outras funções como selagem, vedação e calafetação não deixam de ser um adesivo.

Stevens (1975) demonstrou as principais reações para obtenção dos silicones, partindo da sílica, pela reação de Grignard, e reagindo com vários compostos, como por exemplo: organo metálicos, gases e solventes. A Figura 4 apresenta as principais reações para se chegar ao polímero de silicone. $\mathrm{Na}$ Figura 5 é mostrada a principal estrutura do polímero de silicone. 


$$
\begin{aligned}
& \mathrm{Si}+\mathrm{RCl} \underset{250-280^{\circ} \mathrm{C}}{\stackrel{\mathrm{Cu}^{\circ}}{\longrightarrow}} \mathrm{SiCl}_{4}+\mathrm{RSiCl}_{3}+\mathrm{R}_{2} \mathrm{SiCl}_{2}+\mathrm{R}_{3} \mathrm{SiCl} \\
& \left(\mathrm{CH}_{3}\right) \mathrm{SiCl}_{3}+\mathrm{C}_{6} \mathrm{H}_{5} \mathrm{MgCl} \quad \longrightarrow \quad\left(\mathrm{CH}_{3}\right)\left(\mathrm{C}_{6} \mathrm{H}_{5}\right) \mathrm{SiCl}_{2}+\mathrm{MgCl}_{2} \\
& \left(\mathrm{CH}_{3}\right)_{2} \mathrm{SiCl}_{2}+\mathrm{CH}_{3} \mathrm{MgCl} \longrightarrow\left(\mathrm{CH}_{3}\right)_{3} \mathrm{SiCl}+\mathrm{MgCl}_{2} \\
& \mathrm{HSiCl}_{3}+\mathrm{H}_{2} \mathrm{C}=\mathrm{CH}_{2} \longrightarrow \mathrm{CH}_{3} \mathrm{CH}_{2} \mathrm{SiCl}_{3} \\
& \mathrm{HSiCl}_{3}+\mathrm{HC} \equiv \mathrm{CH} \longrightarrow \mathrm{CH}_{2}=\mathrm{CHSiCl}_{3} \\
& \mathrm{HSiCl}_{3} \underset{\mathrm{BCl}_{3}}{\stackrel{\mathrm{C}_{6} \mathrm{H}_{6}}{\longrightarrow}}\left(\mathrm{C}_{6} \mathrm{H}_{5}\right)_{2} \mathrm{SiCl}_{2}
\end{aligned}
$$

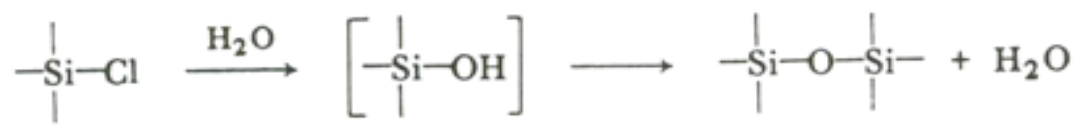

$$
\begin{aligned}
& \left.\mathrm{Cl}-\underset{\prod_{\mathrm{C}}^{\mathrm{i}}-\mathrm{Cl}}{\mathrm{CH}_{3}} \stackrel{\mathrm{H}_{2} \mathrm{O}}{\longrightarrow} \stackrel{\mathrm{Si}-\mathrm{O}}{\mathrm{CH}_{3}}\right]
\end{aligned}
$$

Legenda: $\mathbf{R}=\mathrm{CH}_{3}$ ou $\mathbf{R}^{\prime}=\mathrm{H}$

Figura 4 - Reações para obtenção do polímero de silicone Fonte: Adaptado do livro - (Stevens, 1975)<smiles>[R1][Si]([R12])([R17])O[Si]([R12])([R1])C</smiles>

em que $n$ varia de 0 a 40.000 nos óleos

$R_{1}$ e $R_{2}$ são usualmente os radicais orgânicos: metil, fenil, vinil, fluoropropil, hidroxila, halogênio

Figura 5: Principal estrutura do polímero de silicone Fonte: Adaptado do livro - (Stevens, 1975) 
As reações dos adesivos selantes de silicones, chamados de estruturais, estão envolvidas tanto com seus respectivos silanos quanto suas estruturas extremamente reativas partindo da molécula principal ativa denominada de matriz. Os principais constituintes da matriz, por serem compostos que definem propriedades especiais ao adesivo selante silicone, são estruturas ramificadas do polímero matriz que também são denominados de blocos " $A$ " e "B" ou R' e $R^{\prime \prime}$ respectivamente, correspondendo às ramificações do polímero. Na Tabela 2 estão relacionadas as principais substâncias que fazem parte da estrutura dos silicones. Os silanos são muito importantes nestes tipos de formulações e sua principal função é promover as ligações de adesão na superfície do substrato.

\section{Tabela 2: Principais substâncias que compõe a matriz dos silicones}

\begin{tabular}{|c|c|c|c|}
\hline BLOCO "A" & BLOCO "B" & Método Sintético & $\begin{array}{l}\text { temperatura } \\
{ }^{\circ} \mathrm{C}\end{array}$ \\
\hline carbonato fluoreno 9.9-bis(4-hidroxifenil) & dimetil siloxano & fosgeração e condensação de oligomero & 25-55 \\
\hline carbonato 2,2,4,4- tetrametil-1,3-ciclobutileno & dimetilsiloxano & $\begin{array}{l}\text { condensação de oligomero via reações de } \\
\text { silaminas }\end{array}$ & 130 \\
\hline isoftalato bisfenol A & dimetil siloxano & $\begin{array}{l}\text { condensação de oligomero via reações de } \\
\text { silaminas }\end{array}$ & $130-150$ \\
\hline teraftalato bisfenol A & dimetilsiloxano & $\begin{array}{l}\text { condensação de oligomero via reações de } \\
\text { silaminas }\end{array}$ & 180 \\
\hline teraftalato bisfenol A & fenilmetilsiloxano & condensação de oligomero & $100-220$ \\
\hline hexametileno teraftalato & dimetilsiloxano & $\begin{array}{l}\text { condensação de oligomero via reações de } \\
\text { silaminas }\end{array}$ & 120 \\
\hline Ү-benzil L-glutamato & dimetilsiloxano & $\begin{array}{l}\text { condensação de oligomero via reações de } \\
\text { silaminas }\end{array}$ & 120 \\
\hline Urea & dimetilsiloxano & condensação de oligomero & 75 \\
\hline Urea & aluminiosiloxano & condensação de oligomero & 65 \\
\hline Imida & dimetilsiloxano & - & - \\
\hline
\end{tabular}

Fonte: Adaptado do livro - Engineered Materials Handbook, v.3, Adhesives and Sealants, 1990 
Tanto o bloco A como B descritos na matriz definem propriedades especiais ao adesivo selante de silicone. O principal catalizador para as reações dos adesivos selantes é o dibutil dilaurato de estanho, representado pela seguinte fórmula: $R_{2}^{\prime} \mathrm{Sn}\left(\mathrm{OCOR}{ }^{\prime \prime}\right)_{2}$, onde $R^{\prime}$ (bloco $A$ ) é um alquil de um a quatro átomos de carbono e $R$ "(bloco $B$ ) é um alquil que varia de um a dezessete átomos de carbono (Franta, 1989). O processo de polimerização é baseado em cinética química de reação e os parâmetros de controle da reação são os principais segredos industriais na fabricação dos adesivos selantes de silicone (Stevens,1975 e Seymour, Carraher, 1981).

J.H. Wright registrou a patente U.S. 3.969.309 em 13 de julho de 1976 pela companhia General Electric, descreveu como é produzido um selante de silicone. Autorizando algumas empresas a produzir o selante de silicone partindo do óleo de silicone até o controle para adicionar os promotores de adesão e os estabilizadores da reação até se formar o selante de silicone (Ranney, 1977).

Wake (1976) descreve que os selantes de silicone têm várias vantagens significativas, tais como: ótima flexibilidade, resistência química, boa estabilidade térmica e excelente propriedades dielétricas. É também um excelente adesivo para colagem de vidros, sendo a estabilidade térmica uma das principais vantagens dos adesivos selantes de silicone (Stock, 1962).

A estabilidade térmica dos adesivos selantes de silicone está relacionada com as estruturas do silício, e neste caso elas têm uma condição ótima para resistir temperaturas a partir de $150^{\circ} \mathrm{C}$ (Gould,1968), como mostrado na Figura 6.

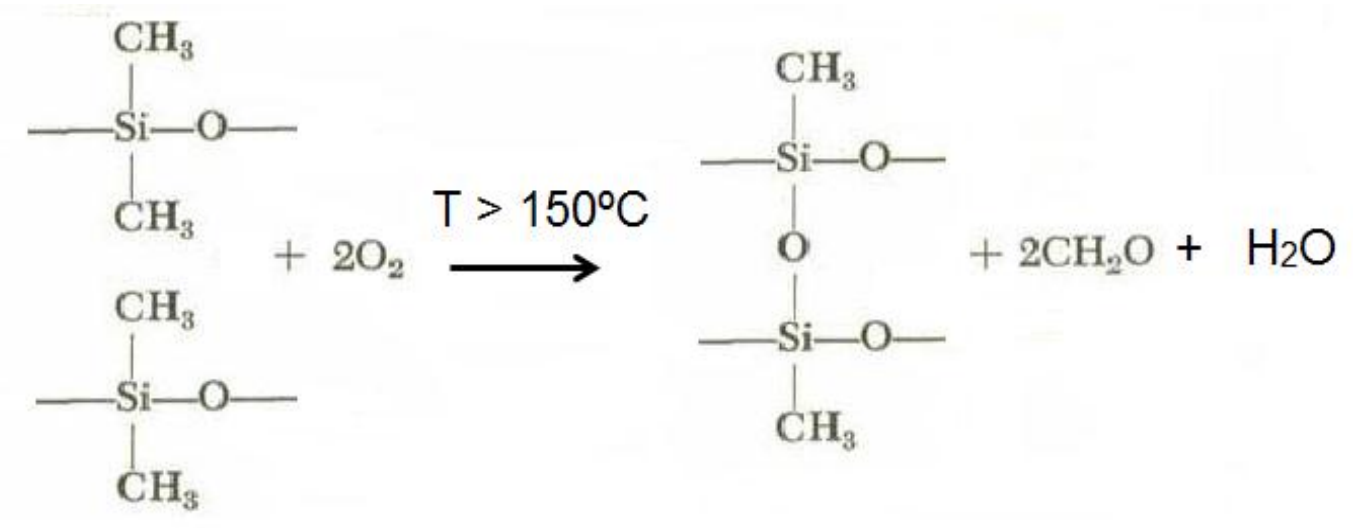

Figura 6: Reação de oxidação do silicone 
Os polisiloxanos, também conhecidos como silicones são os mais importantes polímeros sintéticos com estrutura inorgânica que é a matriz dos adesivos selantes de silicone. Eles apresentam fórmula geral $\left(\mathrm{R}_{n} \mathrm{SiO}_{(4-n)} / 2\right)_{m}$, onde $n=1-3$ e $m \geq 2$, contêm um esqueleto constituído por átomos de silíciooxigênio repetidos o grupos $\mathrm{R}$ (radicais orgânicos) ligados aos átomos de silício, pela da ligação silício-carbono. Nas siliconas comerciais, a maioria dos grupos $R$ são metil, alquil mais longos, flúor-alquil, fenil, vinil e outros poucos grupos que são substituídos para finalidades específicas (Büchner et al., 1989). Entretanto, alguns dos grupos $\mathrm{R}$ podem ser também: hidrogênio, cloro, alcoxi, aciloxi, alquil-amina, etc. Estes polímeros podem ainda estar combinados com carga (filler), aditivos e solventes. Quando recebem solventes em sua formulação são denominados de "silicone estendido", com a principal função de redução de custos. O fato de suas propriedades físicas serem pouco afetadas por temperatura são considerados excelentes selantes térmicos, dentro da classe dos polímeros, seu limite de temperatura está na faixa de 280 a $300^{\circ} \mathrm{C}$. A cura destes materiais é iniciada pela exposição à umidade atmosférica (Damusis, 1967), e está baseada em reações químicas, onde o agente reticulante à medida que reage com a umidade do ar, aumenta a massa molar média, envolvendo a formação de ligações cruzadas. Os produtos mais comumente usados são curados por reações que envolvem acetoxisilanos e, neste caso, a cura se completa pela evaporação do ácido acético resultante. O tempo requerido para a cura depende do tipo de sistema em função da temperatura de exposição, umidade e espessura da camada de silicona, são fatores importantes que interferem no processo de cura do produto. A difusão do ácido acético no interior da matriz polimérica depende do grau de polimerização do silicone. Neto, J.M.M. e Neto, J.M.G. em 1998, realizaram uma experiência sobre a cura do adesivo selante de silicone por meio de medidas de condutividade elétrica do ácido acético produzido e reticulado na matriz do polímero. $\mathrm{O}$ ajuste bi-exponencial dos dados sugere que a quantidade de ácido acético produzido durante a polimerização e remanescente na matriz polimérica resulta de dois diferentes processos: a polimerização superficial e a polimerização no interior da matriz (bulk). A espessura da amostra de silicone afeta estes processos modificando seus parâmetros cinéticos, isto é, sua velocidade de reação. 
Quanto aos mecanismos de reação e ordem de reação são descritos por Hogen-Esch, Smid (1987), que demostram a complexidade que envolve as reações de cura, em função da temperatura, umidade relativa, camada de aplicação e área de contato com o ar, a reação é mostrada na Figura 7. Moita Neto e Guimarães Neto (1998) descrevem sobre o mecanismo de cura dos selantes de silicone.

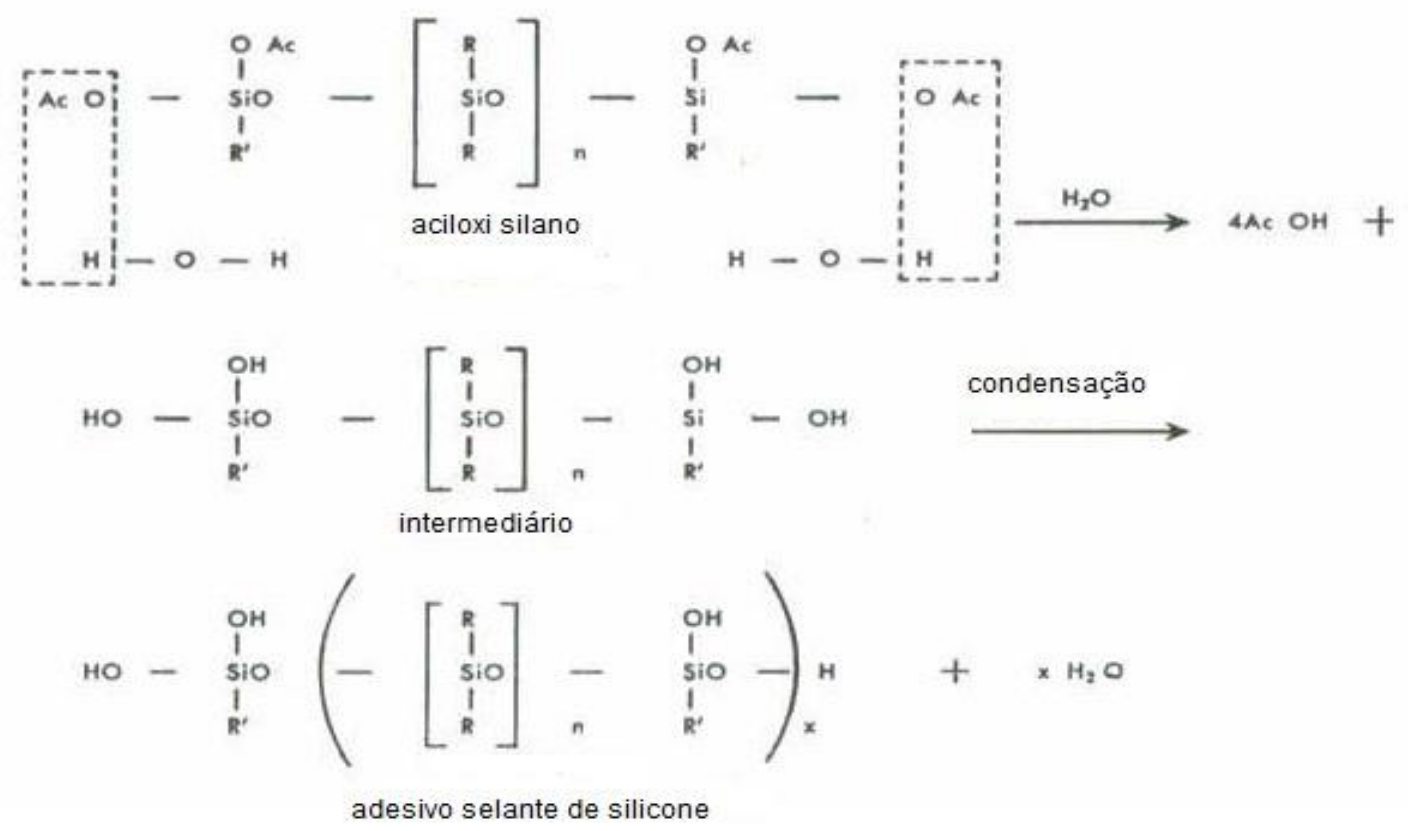

Figura 7: Mecanismo do processo de cura do adesivo selante de silicone - mono componente. Fonte: Adaptado do livro - (Bodnar, 1966)

A difusão do ácido acético no interior da matriz polimérica depende do grau de polimerização do silicone, mas Elvers et al., (1993) deixam bem claro como é o mecanismo de adesão dos adesivos selantes de silicone. Na Figura 8 , está mostrado como o adesivo selante adere à superfície do vidro, onde o átomo de oxigênio da estrutura do silicone realiza uma ligação com o átomo de silício da estrutura do vidro. 


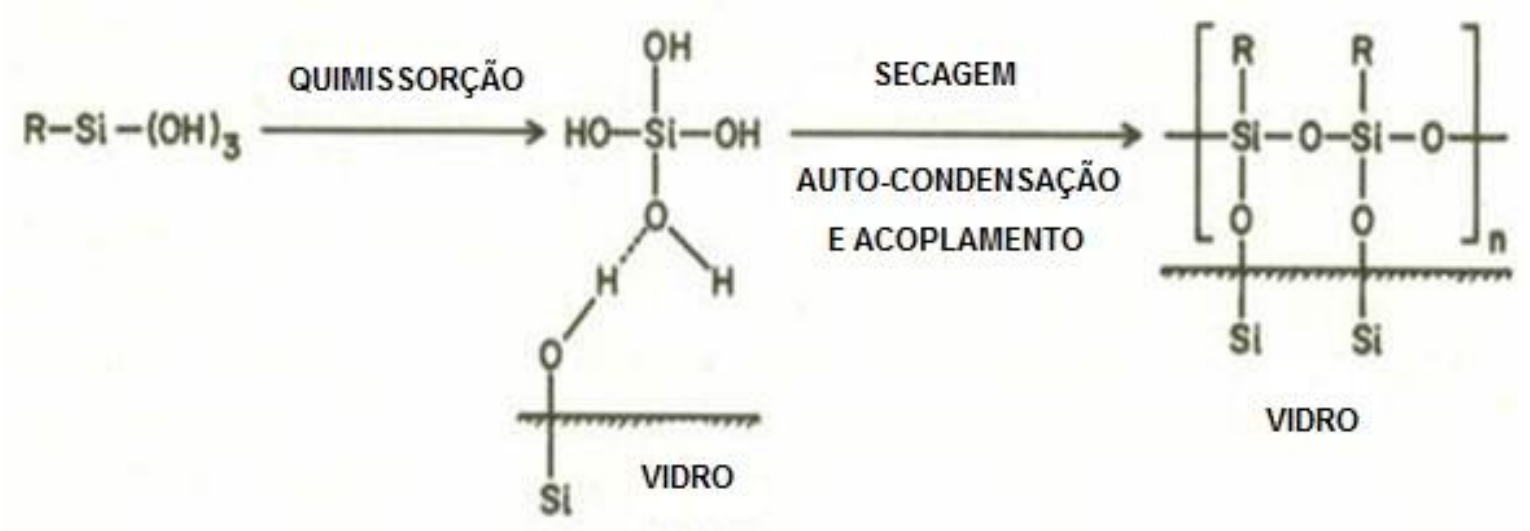

Figura 8: Mecanismo de adesão do selante de silicone no vidro Fonte: Adaptado do livro - (Wu, 1982)

Bever (1986) mencionou que as colagens onde necessitam primers e também as que não necessitam, destacam-se principalmente pelo bom desempenho alcançado mesmo com o avanço de novos materiais. As aplicações chamadas estruturais (adesivos selantes para colagem de vidros em edifícios), que são extremamente criticas, com relação à segurança, a resistência da colagem e sua durabilidade é fundamental neste aspecto. Um adesivo selante silicone contém em sua formulação componentes de sua própria família química, os denominados silanos, estes também são conhecidos como promotores de adesão; estes produtos proporcionam características de adesão especial em função do tipo de substrato a ser aderido (Stepek and Daoust, 1983).

Elvers et al. (1993), explicaram que as estruturas com radicais $\mathrm{SiOH}$, SiOR (radicais orgânicos) ou outros polímeros, possuem uma afinidade maior com os adesivos baseados nas estruturas do silício principalmente os adesivos de silicone, numerosas aplicações foram desenvolvidas, como por exemplo: selantes, adesivos, tintas e coatings. Nestas aplicações tem-se que avaliar também a complexidade das reações envolvidas, que mostram claramente como os polímeros de silicone comportam-se como adesivos, principalmente quando são formulados para sistemas de cura com a umidade do ar. Na Figura 9 é mostrado um exemplo de formulação de adesivo selante de silicone de baixo módulo. 
\begin{tabular}{lc} 
Fórmula de silicone - transparente & $\begin{array}{c}\mathrm{p} / \mathrm{p} \\
\%\end{array}$ \\
Dimetil siloxano hidroxi terminado & 60 \\
Silica (amorfa) & 5 a 10 \\
Metiltriacetoxissilano & 1 a 5 \\
Etiltriacetoxisilano & 1 a 5 \\
Polidimetilsiloxano & 1 a 5 \\
Nafta (petróleo), pesada tratada com hidrogênio & 10 a 30 \\
\hline
\end{tabular}

Figura 9: Exemplo de formulação adesivo selante de silicone de baixo módulo

Fonte: Adaptado do livro - (Petrie, 2007)

Assim como para outros polímeros, as propriedades dos vários tipos de silicones dependem primariamente de sua massa molar, grau de entrecruzamento, forças intermoleculares, rigidez dos segmentos da cadeia e cristalinidade. Os silicones que curam com umidade do ar (Morton, 1987) são vendidos como líquidos pastosos que curam in situ sem aquecimento. Dentre suas várias aplicações estão os adesivos e os selantes muito utilizados na contrução civil, seja na colagem de espelhos, box de banheiro, toldos de policarnonato entre outros materiais. A diferença entre o adesivo e o selante está relacionada diretamente com a sua função como propósito de produto, isto é, colar e vedar, portanto, não deve ser diferenciado somente pela viscosidade ou pela espessura de adesivo aplicado na superfície do material. A principal função é manter os dois substratos colados ao longo do tempo. Para entender melhor o que acontece com o sistema silicone, a teoria tenta explicar as razões pelas quais um material se adere a outro, tanto a teoria mecânica como a de adsorção são as mais próximas possíveis dos silicones. 
A teoria mecânica estabelece que por meio da fluidez a penetração do adesivo em superfícies porosas leva à formação de ganchos ou um entrelaçamento mecânico do mesmo com a superfície do substrato mantendo-os colados por um período de tempo que o mercado define como mínimo de cinco anos, dependendo da exposição da peça, sobre várias condições, como por exemplo: calor, umidade, luz, poeira, elétrica, eletromagnética, magnética entre outras.

A teoria da adsorção estabelece que a adesão resulte do contato molecular entre dois materiais que desenvolvem forças de atração superficiais. $O$ processo de estabelecimento do contato contínuo entre um adesivo e um substrato é chamado de umedecimento, que pode também ser definido como a adesão de um líquido a um sólido.

As aplicações de colagem dos adesivos selantes de silicone derivam da alta viscosidade e da alta polaridade de seus materiais, que possibilitam:

- velocidade no processo de cura e polimerização à temperatura ambiente;

- alta força de coesão, dependendo do tipo da formulação é maior;

- elevada resistência térmica, comparada com outros selantes, na faixa de $250^{\circ} \mathrm{C}$ (Stock, 1962);

- o polímero final tem estrutura e polaridade variável, permitindo muitas oportunidades de ligações com a maioria dos substratos, principalmente os derivados do silício.

Skeist (1990) mencionou aspectos importantes dos adesivos selantes silicones principalmente relacionados à cura do produto. $\mathrm{O}$ catalisador define a velocidade da reação, isto é, a cura do produto. Podendo ser de 12 a 72 horas dependendo das condições do ambiente, geralmente como parâmetro de referência a temperatura foi de $25^{\circ} \mathrm{C}$ e $50 \%$ de umidade relativa do ar. Com o avanço da tecnologia, estes produtos conseguiram um excelente espaço nas indústrias automobilísticas e da construção civil. Um mecanismo simples de adesão no vidro foi proposto por Wu (1982), onde demonstrou exatamente como o promotor de adesão realiza a ligação com o átomo de silício que é um dos componentes da matriz do vidro.

Uma das principais aplicações dos silicones é a colagem de vidros em estruturas de alumínio, como é mostrado na Figura 10. Panek, Cook (1984) não só contribuíram para um melhor entendimento dos mecanismos de cura como 
também descreveram as principais propriedades dos adesivos selantes de silicone. Uma delas é a durabilidade do produto, principalmente em se tratando de colagens de vidros, a norma ASTM C 920 - Elastomeric Joint Sealants (1987), submete o produto a $70^{\circ} \mathrm{C}$, durante 6 semanas, para avaliar a durabilidade da colagem. Este fato está relacionado com o tipo de formulação estrutural que está sendo utilizada. Na Figura 10 tem-se um exemplo de como é aplicado o adesivo selante de silicone, tanto para colar como para vedar um sistema de janelas de alumínio. Uma observação importante é a utilização de um perfil de preenchimento para apoiar melhor o vidro e acomodar a colagem do mesmo.

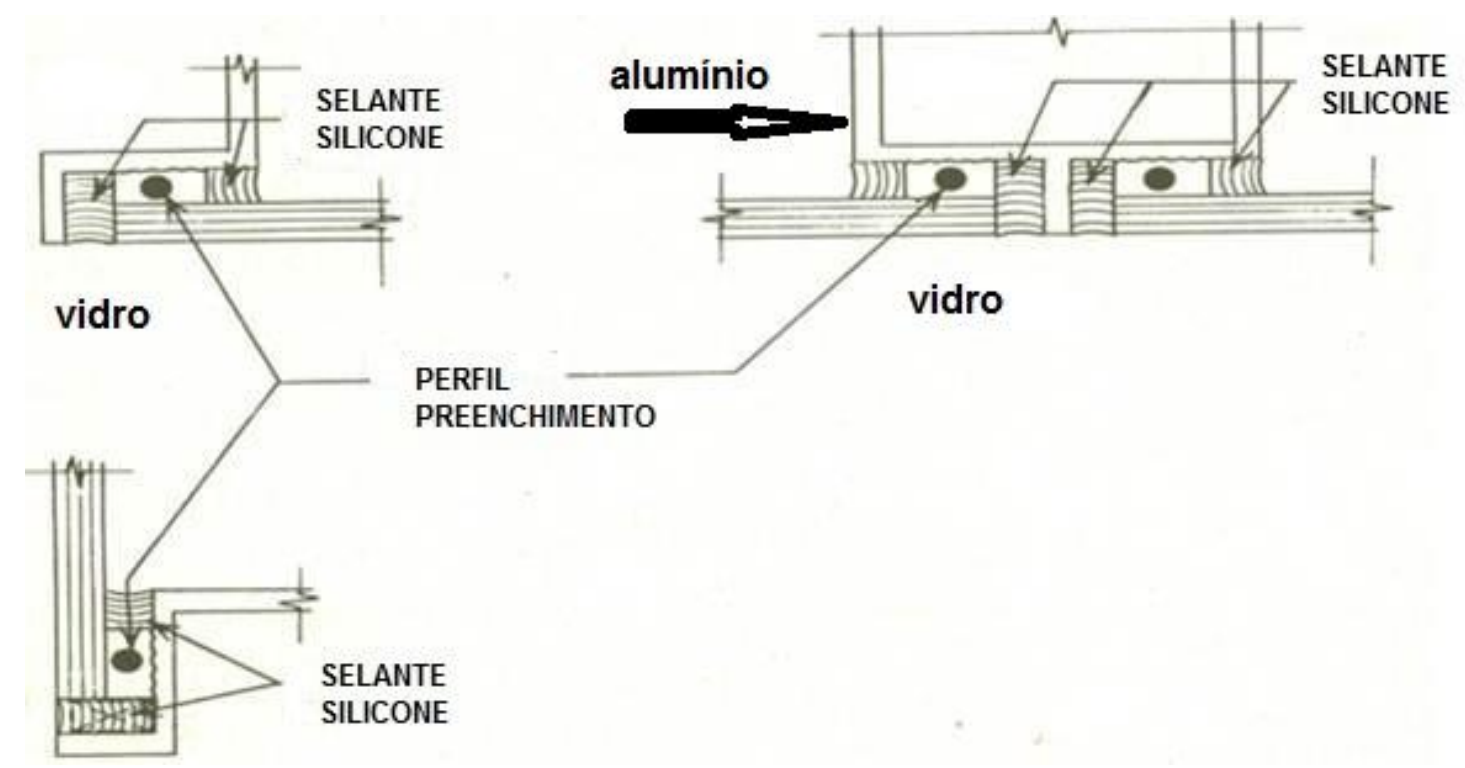

Figura 10: Colagens de vidros com adesivo selante de silicone Fonte: Adaptado do livro - (Panek, Cook, 1984)

Existem vários usos para adesivos de silicone com o sistema de cura com a umidade do ar, que são recomendados, principalmente, para aplicações onde se quer elevada resistência ao calor associada à elevada força de adesão (Landrock,1975). 


\subsection{4 - Selantes e mastic}

Conforme citado no Capítulo 2, adesivos e selantes são muitas vezes considerados como mesmo tipo de produto. O mastic também é considerado um selante, porque eles, além de selarem também vedam, devem ser resistentes ao ambiente onde estarão expostos ou trabalhando, ambos compartilham várias características em comuns. Por isto não se pode esquecer que as características citadas estão atreladas às formas como são aplicados os produtos.

Jackson (1976) descreveu duas possibilidades de formular um selante baseado em borracha butil ou butílica, que são as principais borrachas do sistema mastic. A primeira é usar uma borracha butílica com elevada massa molar, sólida, e que possa ser misturada com solventes e óleos minerais. A segunda possibilidade é misturá-la com polibuteno líquido, a característica de pegajosidade será predominante, podendo assim elevar o conteúdo de carbonato de cálcio para melhorar o custo do produto final. O produto torna-se uma massa não secativa, isto é, não adesiva, esta característica em alguns casos é fundamental para alguns tipos de juntas. Têm-se como exemplo, a construção de estruturas metálicas de alumínio, carrocerias de caminhões baú onde existe pequena movimentação mecânica, que no caso do adesivo poderia atingir a fadiga e comprometer não só a calafetação como também a vedação. A movimentação mecânica e a resistência à umidade, barreira contra água ou infiltração, são algumas das particularidades mais importantes que caracterizam o produto denominado no mercado como mastic.

O mastic hoje é mais encontrado na construção de estruturas metálicas de alumínio. Quando se trata de custo é fundamental analisar as formulações, Flick (1978) demonstrou suas formulações com até $56,5 \%$ de cargas minerais. Hoje com o avanço de novas matérias-primas pode-se atingir até $79 \%$. Por ser um produto não secativo sua validade pode chegar até dois anos como tempo de prateleira.

Estes selantes recebem várias denominações tais como: selante base butil ou butílico, mastic butil, mastic butílico ou simplesmente mastic. No mercado obedecem a uma formulação básica, utilizando como polímero principal a borracha butil que varia de 1 a $3 \%$. Como se trata de um produto de simples 
mistura a estrutura de formulação é basicamente a seguinte: 25 a 30\% de óleos minerais ou naturais, 60 a $79 \%$ de cargas minerais, 0,05 a 3\% de pigmentos, 7 a $18 \%$ de solventes e de 0 a $2 \%$ de aditivos. O polímero secundário é o polibuteno ou poliisobutileno, a quantidade varia de um fabricante para outro, que varia de 1 a $2 \%$. O mastic é um produto não secativo, isto é, em condições ambiente não apresenta sistema de cura, sua formulação é variável (Houwink, Salomon,1965) por causa da grande quantidade de óleo que compõe sua formulação. Nas formulações de mastic não são encontrados agentes vulcanizantes ou de cura, tais como: enxofre, óxido de zinco, óxido de magnésio, entre outros. Por esta razão o mastic torna-se um produto com aspecto de borracha macia, maleável semelhante a uma goma de mascar com elevada pegajosidade. Alguns tipos de mastic adicionam aditivos para formar uma pele "casca" para protegê-los dos raios ultravioletas. Como por exemplo, o “Juntabel”, um produto muito conhecido no mercado brasileiro, que se destacou muito na área da construção civil, na década de oitenta. Skeist (1977) definiu como mastic materiais que contêm óleos secantes ou componentes de betume que com o tempo também formam uma pele na superfície. Estes produtos fixam-se em vários substratos, sempre com o objetivo de preencher cantos ou junções com ângulos diversos.

Como exemplo é apresentado na Tabela 3 algumas formulações de mastic, conforme sugerido por Flick (1984), pode-se, portanto evidenciar a presença tanto do óleo plastificante como do solvente na composição do mastic.

Tabela 3: Exemplos de formulações de mastic

\begin{tabular}{|c|c|c|c|}
\hline Fórmula - Mastic 1 & $\begin{array}{c}\mathbf{p} / \mathbf{p} \\
\%\end{array}$ & Fórmula - Mastic 2 & $\begin{array}{c}\mathbf{p} / \mathbf{p} \\
\%\end{array}$ \\
\hline Polysar XL 50 - borracha butil & 6 & $\begin{array}{l}\text { Solprene 411P - borracha } \\
\text { butil }\end{array}$ & 9,41 \\
\hline Amoco H-300 - polibuteno & 2 & Picco 6100 - resina & 3,14 \\
\hline Keltrol 1001 - solução de resina & 3 & Polymer - polibuteno & 3,14 \\
\hline Thixatrol GST - agente tixotrópico & 0,39 & Escorez 2101 - resina & 6,27 \\
\hline $\begin{array}{l}\text { Atomite - carga mineral } \\
\text { I.T. } 3 X \text { - talco }\end{array}$ & $\begin{array}{l}49,17 \\
25,01\end{array}$ & $\begin{array}{l}\text { Clay - carga mineral } \\
\text { Whiting - carga mineral }\end{array}$ & $\begin{array}{l}25,09 \\
50,19\end{array}$ \\
\hline Ti-Pure R-900 - $\mathrm{TiO}_{2}$ - pigmento & 4,02 & $\begin{array}{l}\text { Naphthenic oil - óleo } \\
\text { naftenico }\end{array}$ & 2,51 \\
\hline Mineral spirits - solvente & 9,96 & Dillydap AO - antioxidante & 0,25 \\
\hline Cobalt drier ( $6 \%$ cobalt) - agente "pele" & 0,03 & & 100 \\
\hline Agerite stalite - antioxidante & 0,12 & & \\
\hline \multirow[t]{2}{*}{ Super Beckacite 2000 - resina fenólica } & 0,3 & & \\
\hline & 100 & & \\
\hline
\end{tabular}

Fonte: Adaptado livro - (Flick, 1984) 
Entretanto Ash, M. e Ash, I. (1987) descreveram uma formulação de mastic com base em borracha butil e polibuteno, utilizando basicamente borracha, carga mineral, óleo plastificante e solvente. Esta formulação baseia-se nos seguintes materiais: Borracha AD-50 (borracha butil), Indopol H-100 (polibuteno), Atomite (carga mineral), Asbetine 3X (antioxidante), Super Sta-Tac 80 (resina sintética), Bentone (agente de tixotropia), Cab-O-Sil (carga mineralsílica) e álcool mineral. É uma massa com qualidades excelentes para vedação e impermeabilização não apresenta nenhum agente de vulcanização ou até mesmo promotor de adesão.

Amelinckx e Van Dyck (1986) descreveram mastic como um produto para vedação e impermeabilização ou colagem de azulejos e revestimentos. Geralmente, estes produtos são capazes de atravessarem aberturas entre os materiais, seja no chão áspero, superfícies de parede ou até mesmo em tetos. São produtos formulados com borrachas sintéticas ou resinas acrílicas que apresentam ótimas condições de trabalho e manuseio apresentando uma forte coesão e uma excelente flexibilidade. Neste caso Amelinckx e Van Dyck (1986) referem-se aos mastics acrílicos onde se tem produtos curáveis ou não, estas condições estão atreladas ao tipo de formulação e necessidades de aplicação. Os mastics acrílicos não curáveis são produtos formulados baseando-se em um sistema híbrido, isto é, o polímero matriz é a resina acrílica. Os mastics, denominados pelo mercado como "curáveis" pertencem à família dos adesivos, por apresentarem um sistema de cura, ou por evaporação da água ou reações de entrelaçamento químico; neste caso estes produtos são denominados de adesivos selantes acrílicos. Podendo ser utilizados, além de sua função principal que é de um adesivo, como calafetador ou vedante para cerâmicas, azulejos de parede, plásticos ou alvenaria. As utilizações destes produtos estão relacionadas ao tipo de obra e custos envolvidos na construção. A aplicação do produto comporta-se como mastic e após algumas horas ou dias atinge sua cura de seu sistema. Como seu comportamento final é de um adesivo pode-se considerá-lo um adesivo selante.

Quanto aos testes Landrock (1975) demostrou qual o produto em função da aplicação e custo benefício que melhor se adapta nas condições da engenharia das construções. 
Klosowski e Smith (1987) definiram selante como sendo um produto que tem como propriedade aderir, vedar e calafetar entre os substratos. Outra propriedade inerente dos selantes é quanto à capacidade de movimentação mecânica dos materiais (substratos) é necessária em função das peças onde o produto será aplicado. Os selantes que Klosowski e Smith se referem são os adesivos selantes de poliuretano, onde varias propriedades estão agora agregadas, sendo que a primeira é do adesivo e a secundária a movimentação mecânica, uma consideração importante é o custo destes produtos que são superiores aos dos adesivos selantes de silicone e aos dos mastic, dependendo da aplicação, muitas propriedades são comuns entre estes selantes.

Dunn (1987) evidenciou as propriedades físicas para melhor definir os adesivos e selantes, embora sendo formulados frequentemente com os mesmos tipos de materiais poliméricos, eles normalmente são projetados para ter propriedades diferentes. Os adesivos têm alta força de cisalhamento que são usadas para substituir ou aumentar o esforço (carga) mecânico das aplicações, quer dizer, são formulações estruturais. Mas dependendo da formulação, com adição de promotores de adesão os selantes apresentam ótimos resultados em relação às forças de cisalhamento. Considerando que são materiais com propriedades importantes, como por exemplo, a flexibilidade que absorve grande parte dos choques mecânicos, a permeabilidade que funciona como uma barreira para a passagem de líquidos, vapores, gases, sólidos, comportando-se como adesivos, e por este motivo recebem a denominação de adesivos selantes. Um grande exemplo são os adesivos selantes de silicone para colagem de vidros em edifícios onde as estruturas metálicas não são visíveis externamente.

Carbary (1987), quando classificou os selantes, analisou uma série de aspectos importantes, tais como: resistência às temperaturas baixas e elevadas, resistência a óleos minerais e sintéticos, verificando seu comportamento. Com estes parâmetros podem ser avaliados os resultados de desempenho do selante em função de sua aplicabilidade. Este desempenho é classificado em: baixa, média e alta, que varia de 0 a $5 \%, 5$ a $12 \%$ e de 12,5 a $25 \%$ aproximadamente da movimentação da junta. Quando se refere à selantes a base de óleo, está se referindo à base butil e os classifica como produto de baixo desempenho, enquanto que os selantes de silicone e poliuretanos são de alto desempenho, com um custo relativamente baixo. As formulações dos mastics apresentam 
sempre cargas minerais, para melhorar o custo da formulação. A aplicação de mastic, normalmente é em lugares internos evitando aplicações exteriores por causa das intempéries. Produto desta natureza tem uma vida útil de 5 a 10 anos dependendo da formulação desenvolvida. Conforme a necessidade da aplicação e especificações de engenharia é possível obter formulações com 95\% de sólidos, este tipo de formulação resiste a um período de tempo maior, atingindo uma vida útil de no máximo 15 anos. Este tipo de produto pode ser empregado na indústria de vidros, como fixação entre os materiais; vidro, alumínio ou ferro, também denominado de massa de vidraceiro, com um custo bem mais baixo em relação a todos os outros tipos de selantes. É preciso salientar que este produto não é indicado para colagens de vidros, e sim fixação, porque caso seja necessária sua remoção são facilmente retirados dos materiais onde foi aplicado.

Quanto aos selantes de poliisobutileno, Carbary (1987) descreveu que basicamente existem dois tipos de mastic: um para aplicação em juntas, com $25 \%$ de solvente, e outro com $100 \%$ de material sólido, que seria produzido por extrusão, ambos sem mecanismo de cura.

Pode-se observar na Tabela 4 que o selante de silicone monocomponente possui um tempo de cura de 5 a 14 dias, este tempo é uma estimativa varia de um fabricante para outro, enquanto para o selante a base butil, ou simplesmente mastic, o tempo de cura é considerado indeterminado. Esta é mais uma evidência que mostra o mastic como um selante que não cura, conhecido no mercado como um selante não secativo. 
Tabela 4: Características dos selantes butil (mastic) e silicone

\begin{tabular}{|c|c|c|}
\hline \multirow{2}{*}{ Características } & \multicolumn{2}{|c|}{ selantes } \\
\hline & butil & silicone \\
\hline Performance & baixa & alta \\
\hline Movimentação recomendada da junta, máximo \% & $+/-7,5$ & $25-30$ \\
\hline Espectativa de "vida" após a cura (anos) & 5 a 15 & 10 a 50 \\
\hline Resistência à Temperatura $\left({ }^{\circ} \mathrm{C}\right)$ & -40 a 82 & -54 a 200 \\
\hline Temperatura de aplicação recomendada $\left({ }^{\circ} \mathrm{C}\right)$ & 4 a 50 & -30 a 70 \\
\hline Tempo de cura sem pegajosidade (Tack-free) & 24 & $1-3$ \\
\hline Tempo de cura (dias) & não cura & $5-14$ \\
\hline Encolhimento (\%) & 20 & $0-5$ \\
\hline Dureza Shore $A, 25^{\circ} \mathrm{C}$, (1 a 6 meses) & $10-30$ & $15-40$ \\
\hline Durezad Shore $\mathrm{A}, 25^{\circ} \mathrm{C}$, ( 5 anos) & $30-50$ & $15-40$ \\
\hline Resistência à extensão a baixa temperatura & moderada, alta & baixa \\
\hline \multirow[t]{3}{*}{ Normas } & TT-S-001657 & ASTM C 920 \\
\hline & & TT-S-00230C \\
\hline & & TT-S-001543A \\
\hline
\end{tabular}

Fonte: Adaptado do Livro - Engineered Materials Handbook, v.3, Adhesives and Sealants, 1990

\subsection{5 - Recomendações para durabilidade da colagem}

Sharpe (1987) explicou que a durabilidade da junta adesiva é influenciada não somente pelas propriedades do adesivo, mas sim pela preparação das superfícies que serão "coladas".

Para se conseguir uma boa "colagem" é recomendável:

- remover o pó, óleo ou qualquer outro material capaz de reter o ar ou impedir o contato do adesivo com a superfície;

- eliminar qualquer substância que possa comprometer a "colagem";

- lixar as superfícies muito rugosas promovendo um contato melhor para o fluxo do adesivo;

- durante a secagem ou cura o adesivo não deve sofrer retrações exageradas, responsáveis por tensões excessivas nas ligações. 


\subsection{6 - Propriedades mecânicas do silicone e do mastic}

As propriedades mecânicas compreendem a resposta dos materiais às influências mecânicas externas, manifestadas pela capacidade de desenvolverem deformações reversíveis e irreversíveis, e resistirem à fratura. Essas características dos materiais são geralmente avaliadas por meio de ensaios, que indicam dependências tensão-deformação. Assim, as características dos polímeros, que se refletem nas suas propriedades mecânicas, podem ser quantificadas por meio de métodos cujo empirismo é contrabalançando pelo rigor das condições, estabelecidas nas normas técnicas, que neste estudo adotou-se as American Society for Testing and Materials (ASTM). As propriedades mecânicas mais importantes decorrem de processos onde há grandes relaxações moleculares, como relaxação sob tensão, escoamento sob peso constante e histerese. Essas relaxações dependem muito da temperatura, da capacidade de desenvolver deformações reversíveis pronunciadas, que são maiores em elastômeros, bem como da íntima correlação entre processos mecânicos e químicos, os quais se influenciam mutuamente de modo substancial, estas considerações são bem descritas por Sharpe (1987), inclusive como escolher o adesivo e as condições de sua aplicação.

\subsection{7- Propriedades elásticas do silicone e do mastic}

O silicone e o mastic são avaliados pela norma ASTM D 412. As propriedades são características importantes da resistência destes produtos. $\mathrm{O}$ corpo de prova é deformado uniaxialmente por tração a uma velocidade padrão constante até a sua ruptura (ASTM D 412). A resistência à tração é avaliada pela carga aplicada por unidade de área no momento da ruptura (Figura 11A). $\mathrm{O}$ alongamento representa aumento percentual do comprimento da peça sob tração, no momento da ruptura (Figura 11B).

A resistência à tração e o alongamento na ruptura podem ser correlacionados quantitativamente com a estrutura do polímero. Materiais com grande teor de ligações cruzadas, como os utilizados nas espumas rígidas, porém quebradiços, e os elastômeros e as espumas flexíveis têm alongamento na ruptura muito maior. A parte inicial em linha reta da curva de tensão/deformação, 
onde 0 material exibe perfeita elasticidade, representa 0 desenvolvimento e alinhamento das cadeias macromoleculares longas e flexíveis. Extensão posterior do polímero acarreta deslizamento das macromoléculas com o rompimento de ligações secundárias entre cadeias adjacentes, podendo resultar em deformações permanentes. Os silicones apresentam resultados semelhantes aos elastômeros, no entanto no mastic este ensaio não é possível mensurar devido a sua consistência não apresentando a cura do material.

A) Resistência à tração: $\mathrm{Rt}=f$ (força de tensão) $/ \mathrm{A}_{\circ}$ (área de seção reta inicial);

B) Alongamento: $e=\mathrm{I}_{0}-\Delta \mathrm{I}_{0}$ (variação do comprimento) $/ \mathrm{I}_{0}$ (comprimento inicial);

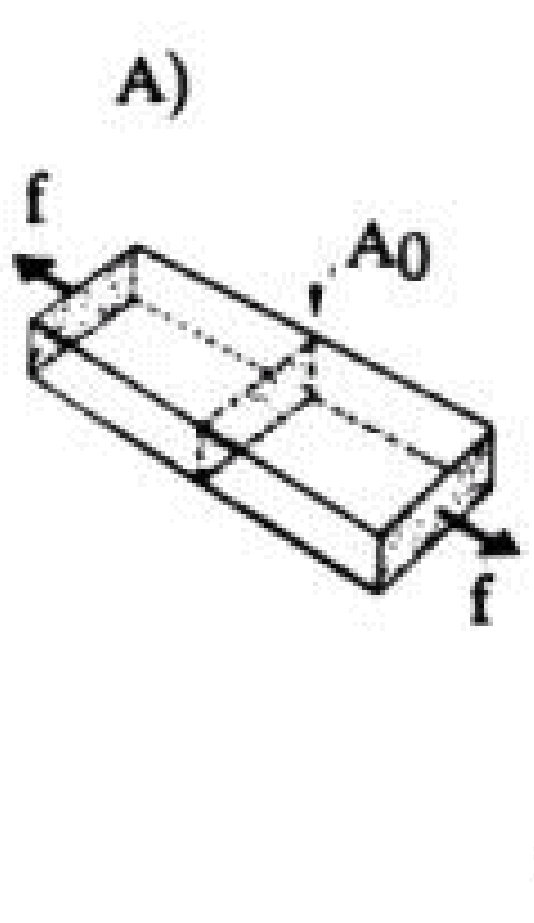

$11 \mathrm{~A}$

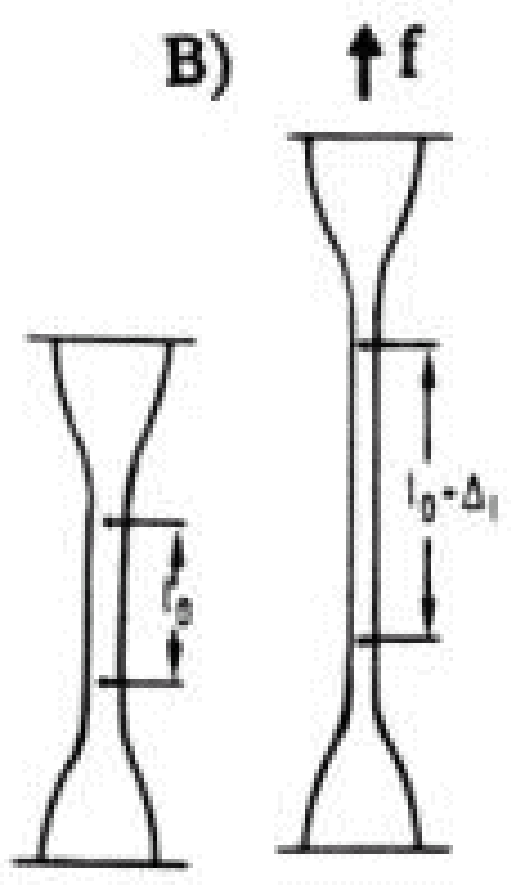

11B

Figura 11: Ensaio Mecânico: Tração (11A) e (11B)

Fonte: Adaptado do livro - Engineered Materials Handbook, v.3, Adhesives and Sealants, 1990 


\subsection{8 - Funcionalidade de um produto}

Um produto quando é formulado tem como objetivo satisfazer uma certa função, essa função poderá ser de diversas ordens segundo o tipo de produto em questão. As características de um produto obedecem a requisitos técnicos elaborados por equipes de especialistas com a finalidade de definir parâmetros para as funcionalidades desse mesmo produto. Neste âmbito pode-se dizer que a funcionalidade de um produto como no caso deste estudo, adesivo selante tem como principal função manter os substratos aderidos ou colados, além de realizar também as funções de calafetação e vedação. Enquanto que o mastic tem como função principal somente a vedação e calafetação, sob condições de pequenas movimentações mecânicas. 


\section{MATERIAIS E MÉTODOS}

Os materiais e métodos utilizados na análise sobre a capacidade de adesão do adesivo selante silicone e do mastic butílico são descritos a seguir.

Os materiais utilizados no experimento têm as seguintes especificações conforme informe o fabricante (BRASCOLA).

Brascoved Super (borracha de silicone): aparência $\rightarrow$ pasta macia; cor $\rightarrow$ transparente; massa específica a $25^{\circ} \mathrm{C} \rightarrow 0,955 \mathrm{~g} / \mathrm{cm}^{2}$; tempo de formação película $\rightarrow 7$ minutos; dureza shore $A \rightarrow 17$; rendimento (cordão $1 / 4$ ") $\rightarrow 30 \mathrm{~g} / \mathrm{m}$ linear, validade 12 meses; lote fabricação 0011270210 .

Brascoved 15/13 CV (mastic butílico): aparência $\rightarrow$ massa; cor $\rightarrow$ cinza; massa específica a $25^{\circ} \mathrm{C} \rightarrow 1,290 \mathrm{~g} / \mathrm{cm}^{3}$; sólidos $\left(180^{\circ} \mathrm{C}, 15\right.$ minutos $) \rightarrow 82 \%$; rendimento (cordão $1 / 4$ ") $\rightarrow 60 \mathrm{~g} / \mathrm{m}$ linear, validade 24 meses; lote fabricação 0012580210.

O solvente xileno (industrial) com densidade de $0,866 \mathrm{~g} / \mathrm{cm}^{3}$, ponto de ebulição inicial $143^{\circ} \mathrm{C}$ a $101,325 \mathrm{kPa}(760 \mathrm{mmHg})$, fornecido na quantidade de 5 litros pela empresa BRASCOLA.

Os corpos de prova para ensaios de tensão cisalhamento, foram utilizados chapas de alumínio (Alumi Copper 7075-T651, dureza 160Hb), cortados nas seguintes medidas: 177,8 mm de comprimento, 25,4 mm de largura e 1,62 mm de espessura.

Os corpos de prova para ensaios de radiação ionizante foram utilizados cilindros de polietileno, cor transparente com as seguintes medidas: $60 \mathrm{~mm}$ de diâmetro e 7 mm de altura.

Neste trabalho realizou-se um estudo prático de várias normas ASTM, com o objetivo de escolher as mais significativas em relação ao comportamento das forças de adesão, que atendessem tanto ao adesivo selante de silicone como o mastic butílico, como sendo os métodos utilizados para os ensaios, estas normas são as mais significativas para os estudos dos selantes. Segue a sequência das normas: D 412 (2002) - Vulcanized Rubber and Thermolastic Rubbers and Thermoplastic Elastomers - Tension; D 1002 (2001) - Apparent Shear Strength of Single-Lap-Joint Adhesively Bonded Metal Specimens by Tension Loading (Metal-to-Metal); D-2765 (1995) - Determination of Gel Content 
and Swell Ratio of Crosslinked Ethylene Plastics e D-3418(1982) Transition Temperatures of Polymers by Thermal Analysis.

Após o estudo foi elaborado um planejamento dividido em duas partes, a primeira as amostras não foram irradiadas e a segunda na presença da radiação ionizante.

As normas escolhidas foram ensaiadas em sistemas de ciclos, isto é, após a aplicação dos produtos foram realizados ensaios com 7, 14 e 28 dias respectivamente, que denominamos de ciclo de 7 dias, ciclo de 14 dias e ciclo de 28 dias. Estes ciclos são um acompanhamento do comportamento dos processos de cura ao longo do tempo.

Nem todos os ensaios realizados utilizaram os três ciclos em virtude dos próprios resultados apresentados. Segue a continuação dos ensaios que foram escolhidos para este trabalho.

Para facilitar os ensaios, às amostras (produtos) fornecidas pela empresa Brascola receberam as seguintes denominações:

- massa de vedação Brascoved 15/13 CV, foi denominado de mastic;

- borracha de silicone Brascoved Construção Transparente, foi denominado de silicone.

\section{1 - ENSAIOS DE ALONGAMENTO E RUPTURA}

As amostras, tanto de mastic como de silicone foram preparadas em forma de uma manta. No vigésimo nono dia após a sua aplicação em forma de manta, Figuras 12 e 15, foram submetidas aos ensaios de alongamento e ruptura conforme a norma ASTM D 412 (2002), método A. Na amostra do silicone foi possível extrair os corpos de prova e realizar o ensaio conforme as Figuras 12, 13 e 14 respectivamente. Não foi possível a realização dos ensaios mecânicos em amostras de mastic como podemos ver Figuras 15, 16 e 17. O equipamento utilizado foi uma máquina universal de ensaio, marca Instron, modelo 3367, com célula de carga $30 \mathrm{kN}$ da empresa BRASCOLA. A temperatura do ensaio foi de $23 \pm 2^{\circ} \mathrm{C}$ e umidade relativa de $50 \pm 5 \%$. A velocidade do ensaio foi de $500 \pm 50 \mathrm{~mm} / \mathrm{min}$. 


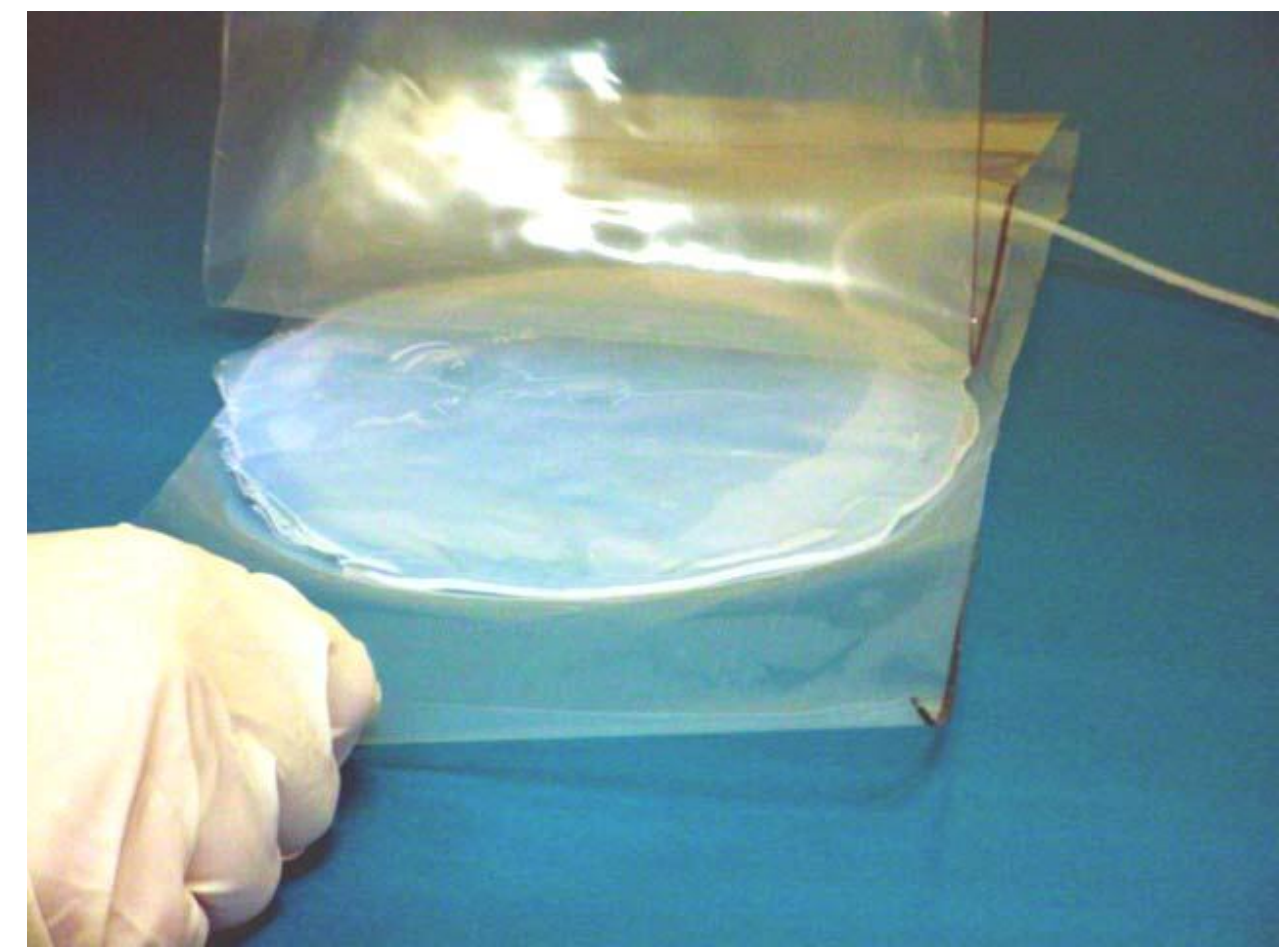

Figura 12 - Manta de silicone, após 28 dias da aplicação Fonte: Laboratório da empresa Brascola

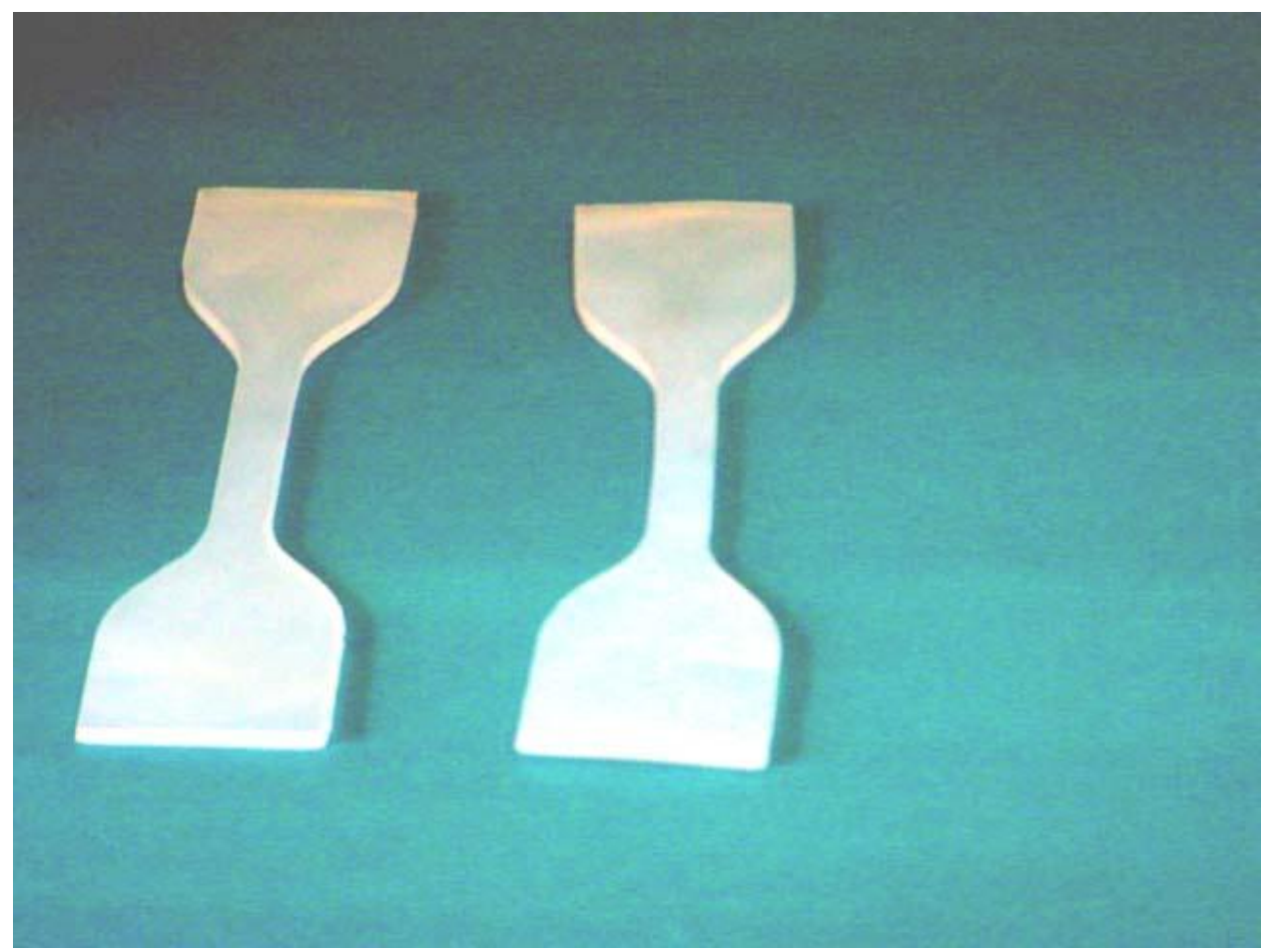

Figura 13 - Corpos de prova de silicone, após 28 dias da aplicação, preparados conforme a norma ASTM D 412

Fonte: Laboratório da empresa Brascola 


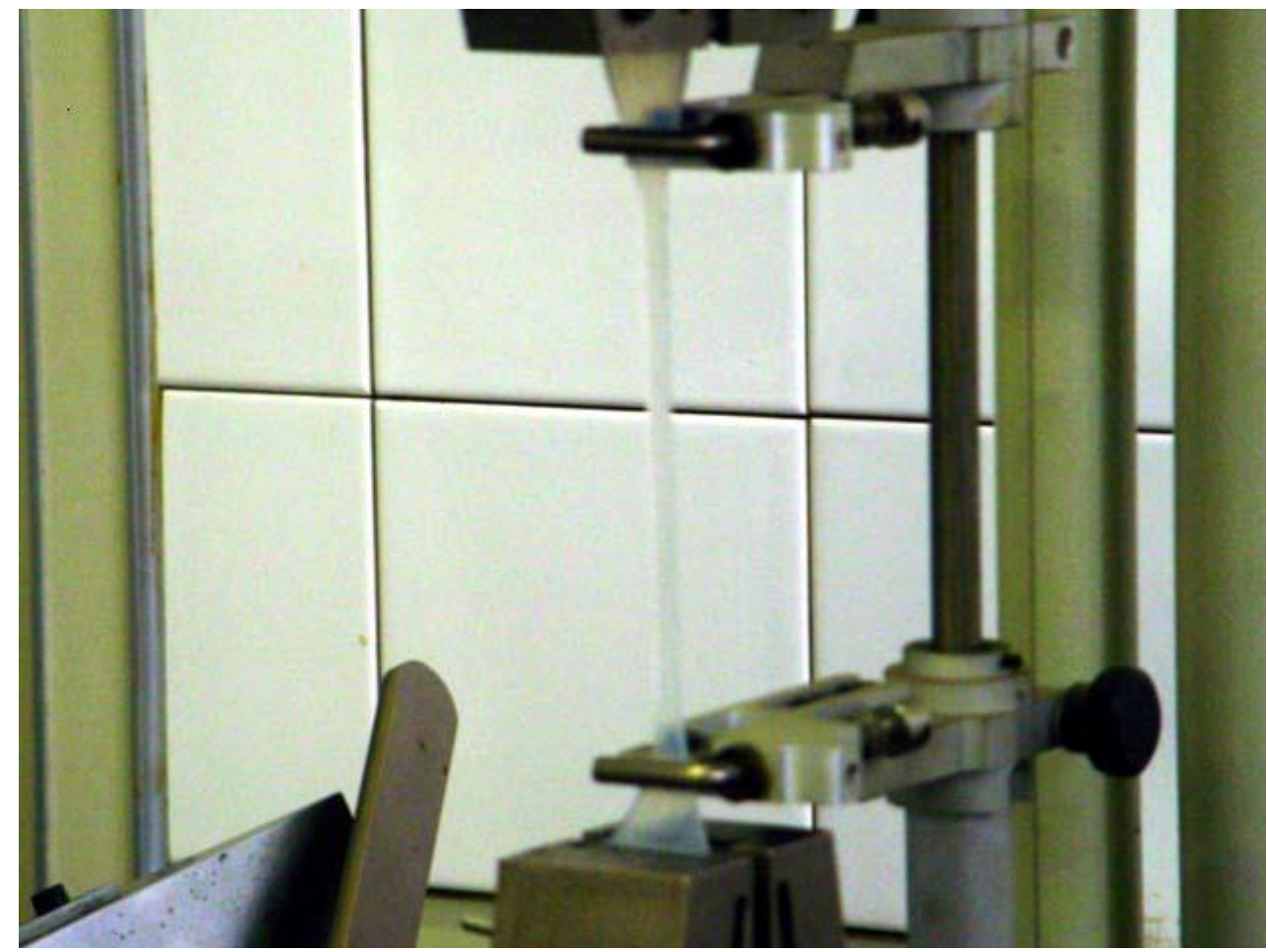

Figura 14 - Corpos de prova de silicone no ensaio de alongamento até a ruptura

Fonte: Laboratório da empresa Brascola

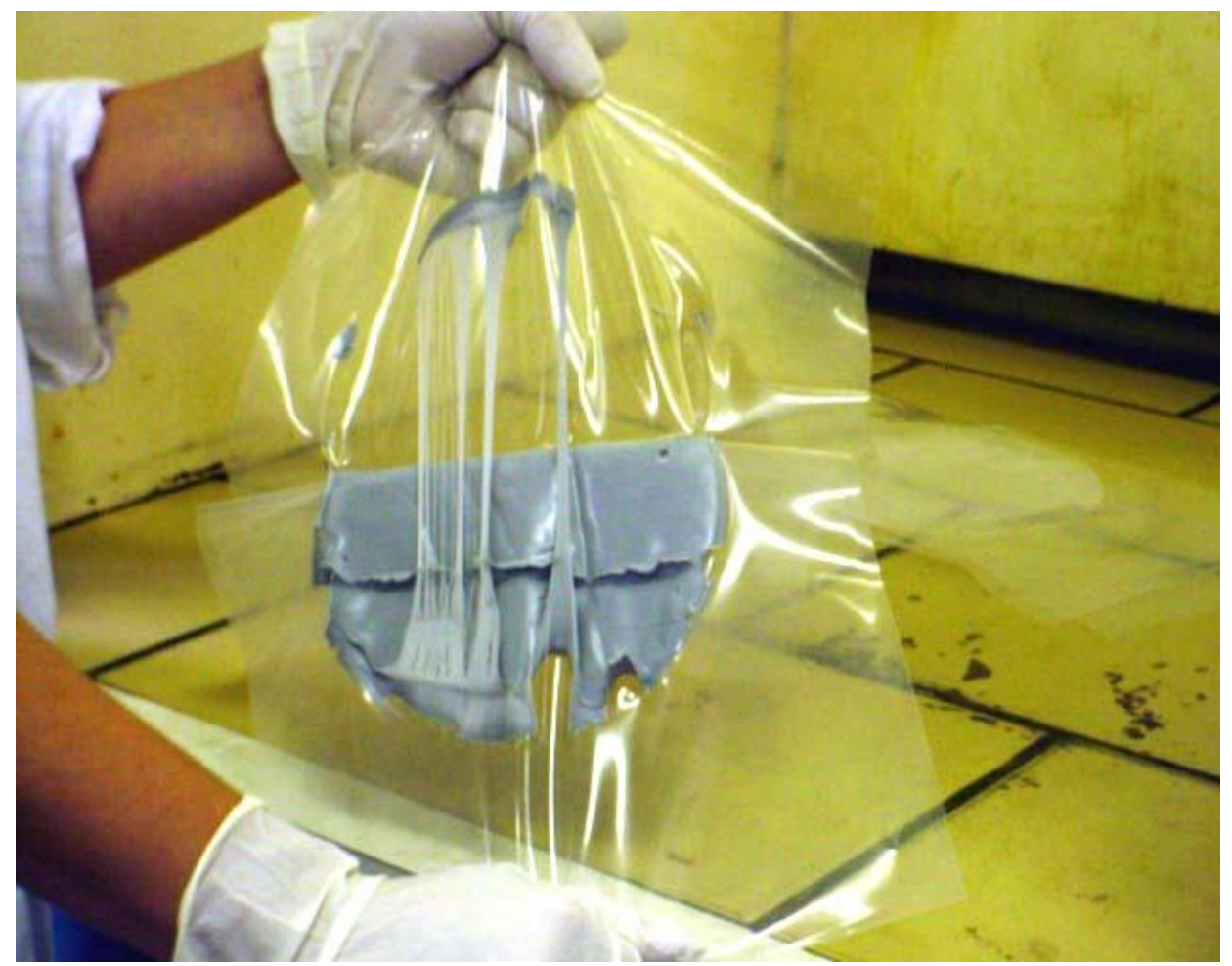

Figura 15 - Manta de mastic, após 28 dias da aplicação

Fonte: Laboratório da empresa Brascola 


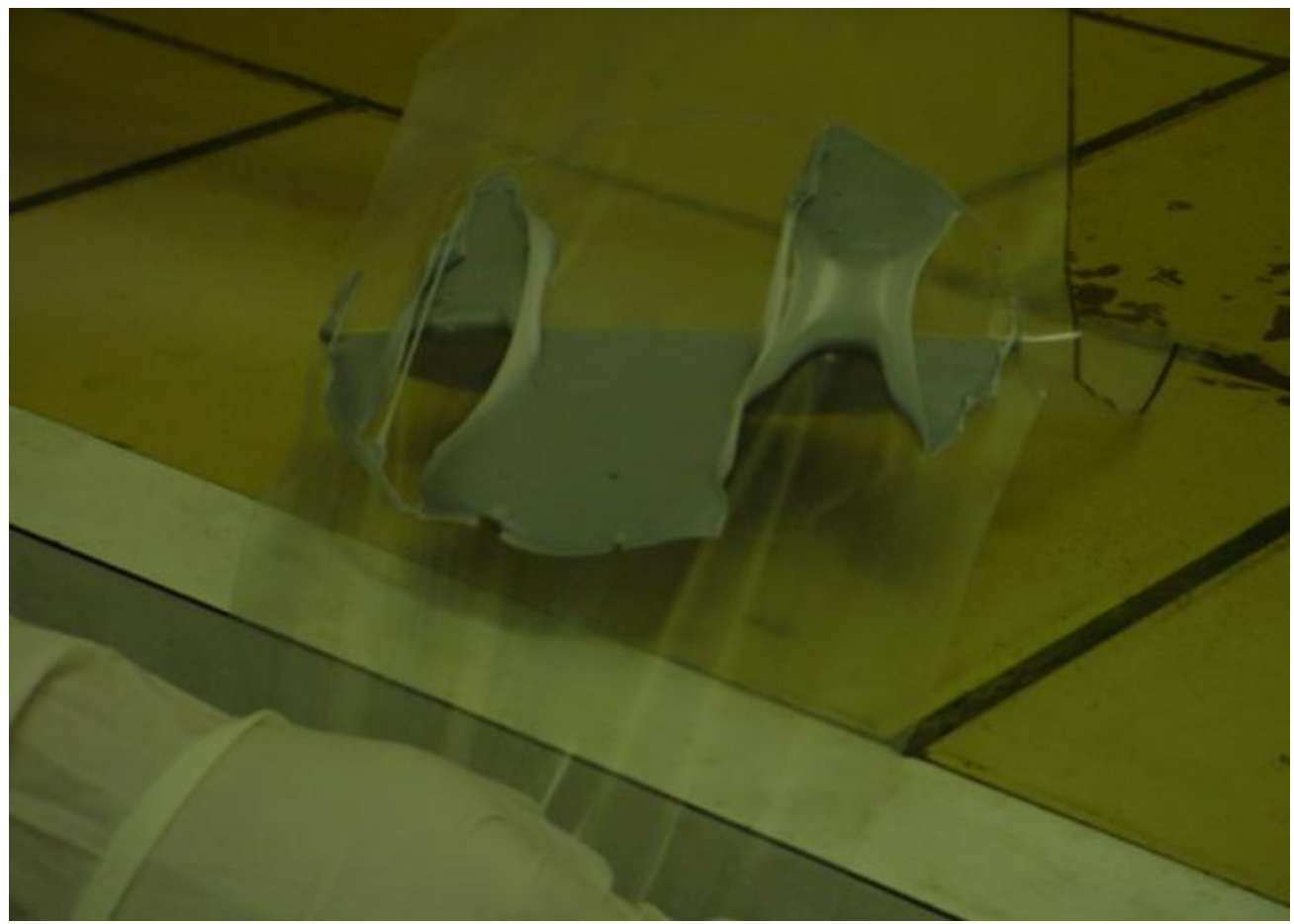

Figura 16 - Manta de mastic, após 28 dias da aplicação, sem condições para o ensaio de ruptura

Fonte: Laboratório da empresa Brascola

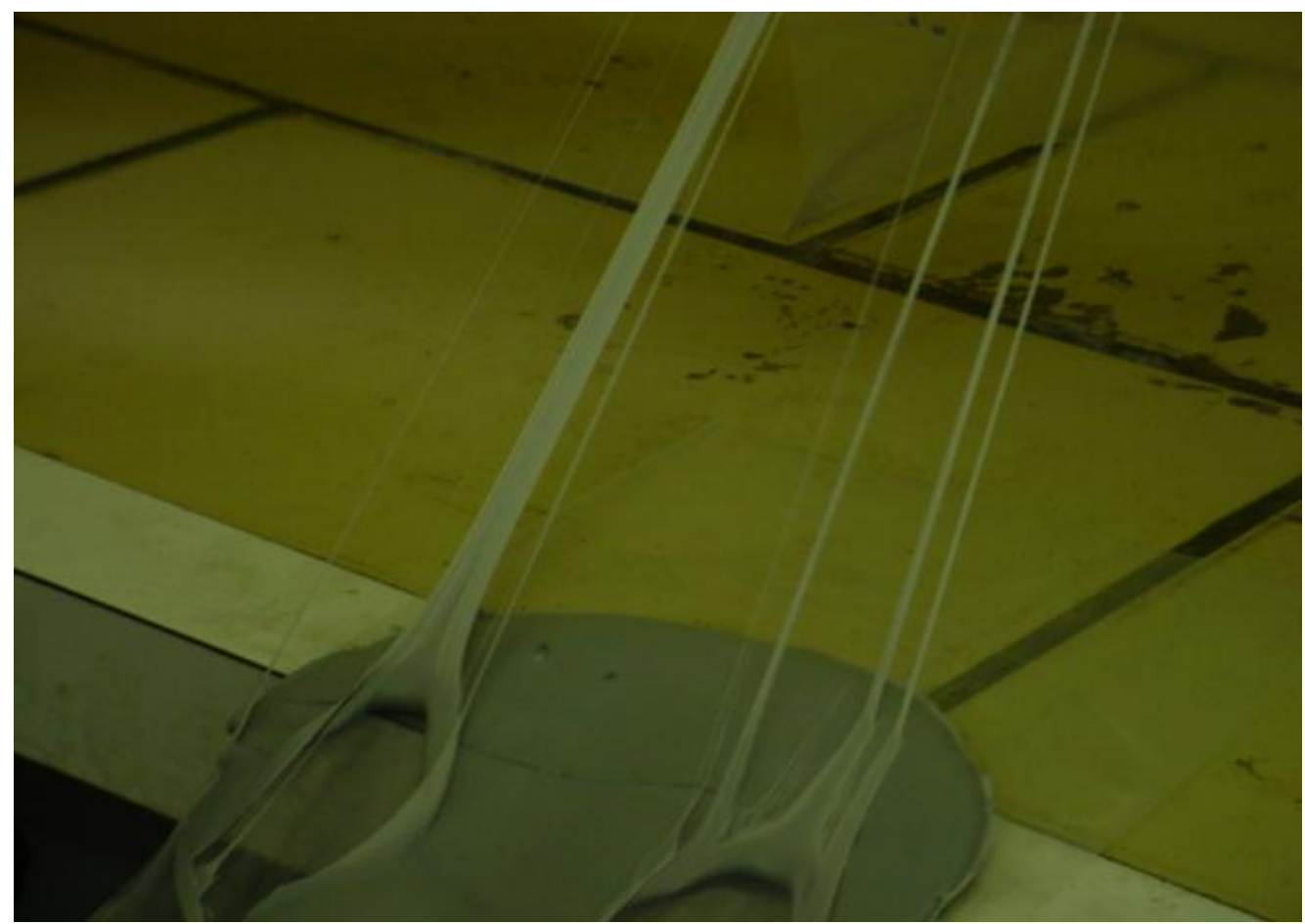

Figura 17 - Manta de mastic, após 28 dias de sua aplicação não apresenta a cura do material

Fonte: Laboratório da empresa Brascola. 


\subsection{ENSAIO DE GRAU RETICULAÇÃO}

O ensaio de reticulação foi realizado conforme a norma ASTM D 2765 Determination of Gel Content and Swell Ratio of Crosslinked Ethylene Plastics (1995), para determinar a reticulação dos sistemas em 7, 14 e 28 dias após ter sido aplicado. Os corpos de prova tanto do mastic como do silicone foram preparados em um recipiente cilíndrico com as seguintes dimensões: altura de $7 \mathrm{~mm}$ e diâmetro de $60 \mathrm{~mm}$, aqui denominados de "cilindros", conforme a Figura 26. As amostras variaram de 0,3 a 1,2 gramas aproximadamente todas em triplicata. O solvente utilizado para o ensaio foi xileno (industrial) fornecido pela empresa Brascola, com densidade de $0,866 \mathrm{~g} / \mathrm{cm}^{3}$, ponto de ebulição inicial $143^{\circ} \mathrm{C}$ a $101,325 \mathrm{kPa}(760 \mathrm{mmHg})$. O volume foi de $100 \mathrm{~mL}$, com temperatura de extração de $82 \pm 2^{\circ} \mathrm{C}$ e tempo de extração de 24 horas. Com utilização de condensador de refluxo. Este ensaio foi realizado no IPEN conforme relatório técnico Silva et al. (2003).

\subsection{ENSAIO DE CALORIMETRIA EXPLORATÓRIA DIFERENCIAL (DSC)}

As curvas de calorimetria exploratória diferencial (DSC-Differential Scanning Calorimetry) foram obtidas utilizando o equipamento DSC-50 Shimadzu e Q20 v 24.2 Build 107 de fluxo de calor, calibrado com padrões metálicos de índio e chumbo. Os ensaios foram executados conforme a norma ASTM D 3418 Transition temperatures of polymers by thermal analysis (1982), os corpos de prova foram retirados dos "cilindros" conforme a Figura 26, pesando entre 6,0 e 9,5 mg aproximadamente, com uma taxa de aquecimento de $10{ }^{\circ} \mathrm{C} / \mathrm{min}$, atmosfera dinâmica de nitrogênio, vazão de gás de arraste de $50 \mathrm{~mL} / \mathrm{min}$ em cápsula de alumínio. Os ensaios iniciaram com temperatura de $50^{\circ} \mathrm{C}$ chegando até a temperatura de $450^{\circ} \mathrm{C}$ aproximadamente.

\subsection{ENSAIO MECÂNICO: TRAÇÃO}

As amostras utilizadas nos ensaios mecânicos de tração foram realizadas conforme a norma ASTM D 1002 (2001), que é a principal norma para avaliar a adesão na área de adesivos. Em ambas as amostras (mastic e silicone) foram 
utilizados chapas de alumínio de $2 \mathrm{~mm}$ espessura (Alumi Copper 7075-T651, dureza $160 \mathrm{Hb}$ ) denominadas de corpo de prova. Os corpos de provas foram preparados pelo laboratório de Pesquisa e Desenvolvimento da empresa Brascola. Foram cortados nas seguintes medidas: $177,8 \mathrm{~mm}$ de comprimento, 25,4 mm de largura e 1,62 mm de espessura, sempre observando as tolerâncias estabelecidas pela norma ASTM D-1002 (2001) as amostras foram colocadas conforme a amostra dos materiais. Foram preparadas quantidades suficientes para contemplar o planejamento, tanto dos sistemas com e sem radiação ionizante, como contemplar também os ciclos de cura de 7, 14 e 28 dias após a aplicação das amostras. Todos limpos com solvente acetona antes da aplicação dos produtos silicone e mastic. Nas Figuras 18, 19, 20 e 21 é mostrada a preparação dos corpos de provas do mastic e do silicone respectivamente. Nas Figuras 22, 23, 24 e 25 são mostrados os corpos de provas do mastic e do silicone respectivamente, sendo tracionados até a descolagem dos mesmos. Todos os corpos de prova, tanto de silicone como de mastic a área aplicada de material foi de $25,4 \mathrm{~mm}$ de largura por $25,4 \mathrm{~mm}$ de comprimento com uma espessura de $2 \mathrm{~mm}$ utilizando-se gabaritos de vidro para uma melhor uniformidade dos materiais nos corpos de provas. O objetivo deste experimento é o de verificar o comportamento das tensões de cisalhamento, isto é, o comportamento do sistema de cura (reticulação) dos sistemas. O equipamento utilizado é o mesmo descrito no item 3.1. A decisão de escolher a norma ASTM D 1002 (2001), para testes físicos tem como base as explicações de Shields (1976), nas quais ele menciona que estes testes físicos são mais significativos para verificação da adesão dos sistemas de adesivos como de selantes, em função das tensões de cisalhamento que estão diretamente relacionadas com as forças de adesão e coesão dos produtos envolvidos nas formulações. 


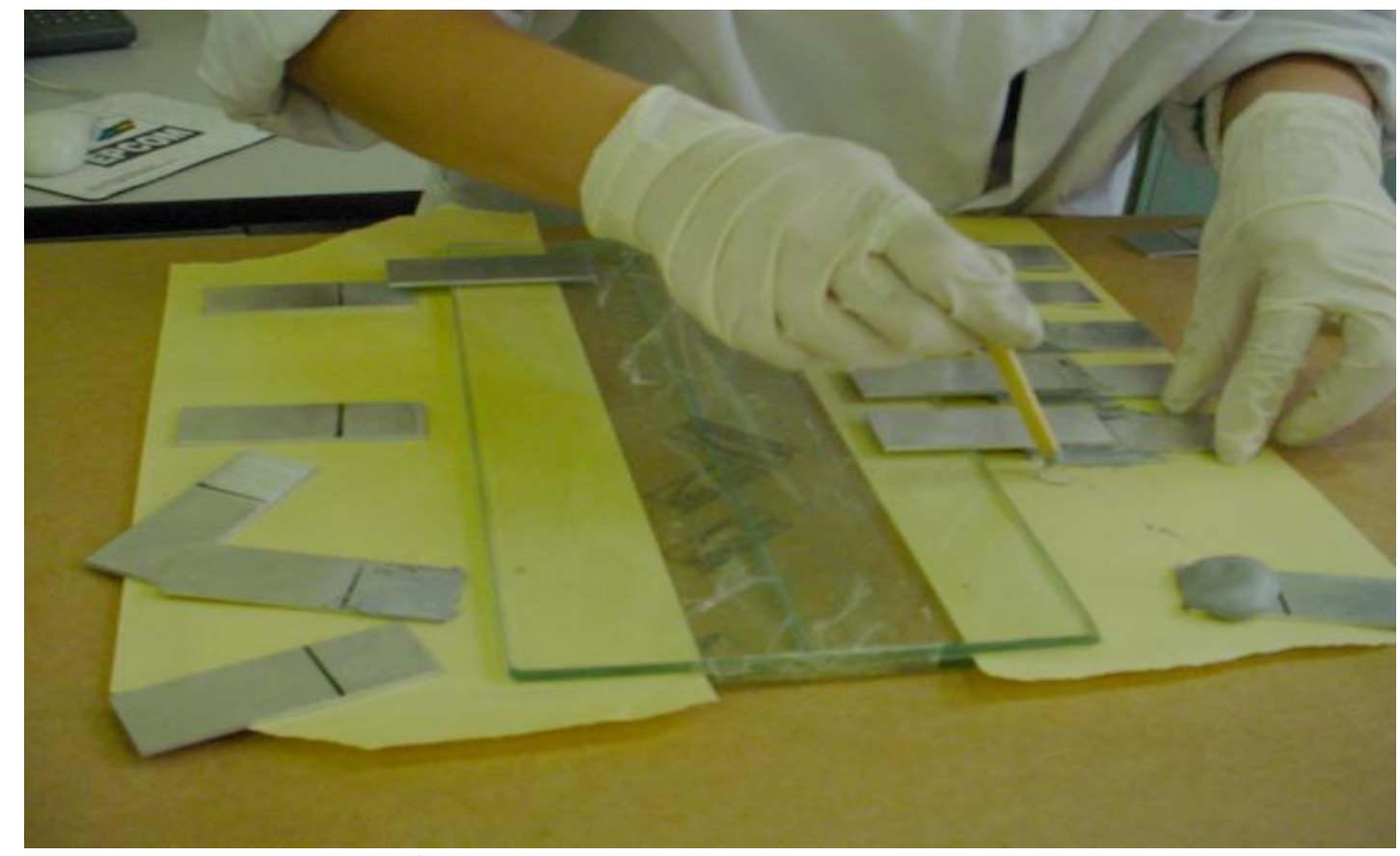

Figura 18 - Preparação dos corpos de prova de mastic, retirando excesso de material

Fonte: Laboratório da empresa Brascola

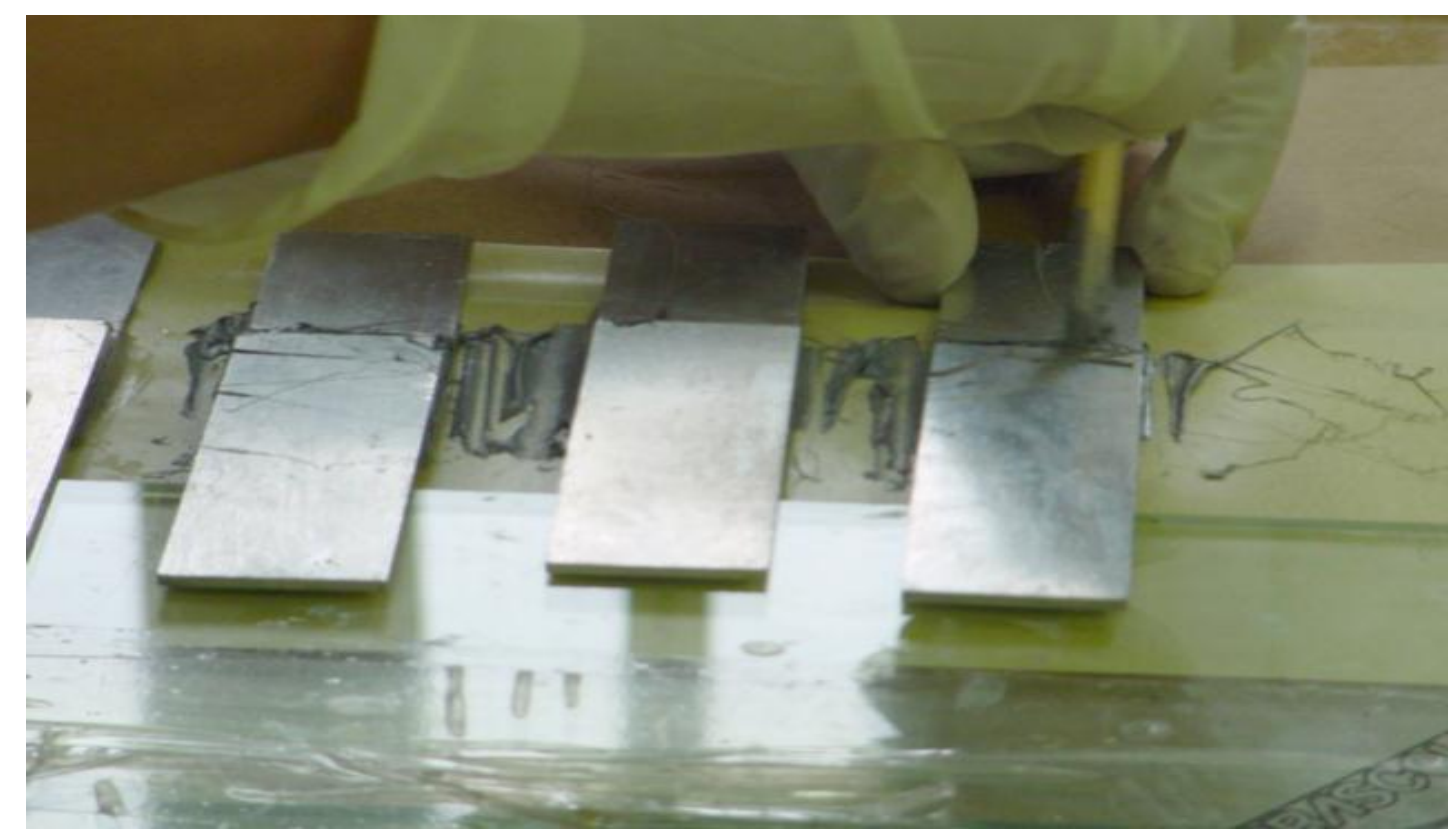

Figura 19 - Preparação dos corpos de prova de mastic, ajustando no gabarito Fonte: Laboratório da empresa Brascola 


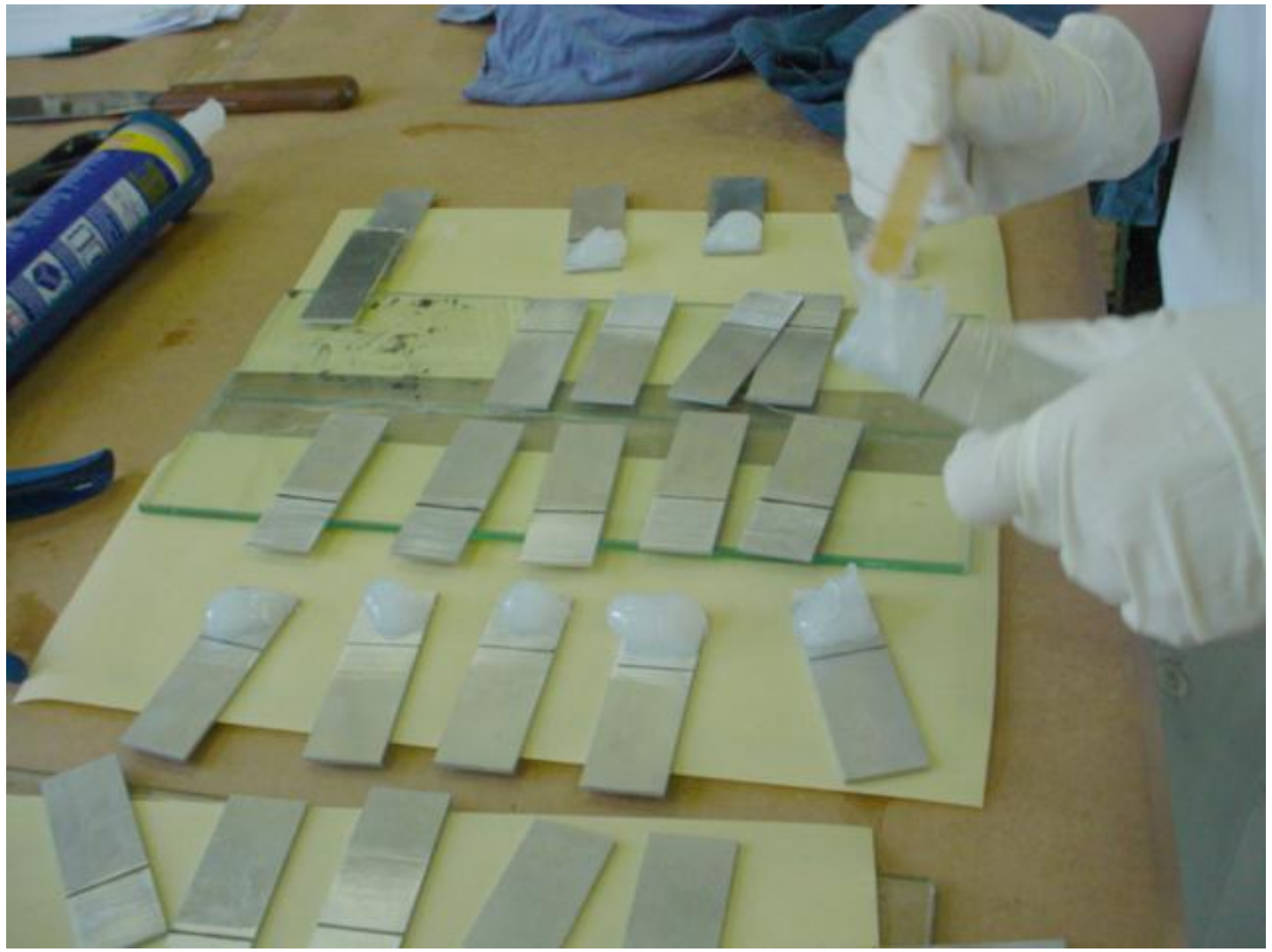

Figura 20 - Preparação dos corpos de prova de silicone, aplicando o material

Fonte: Laboratório da empresa Brascola

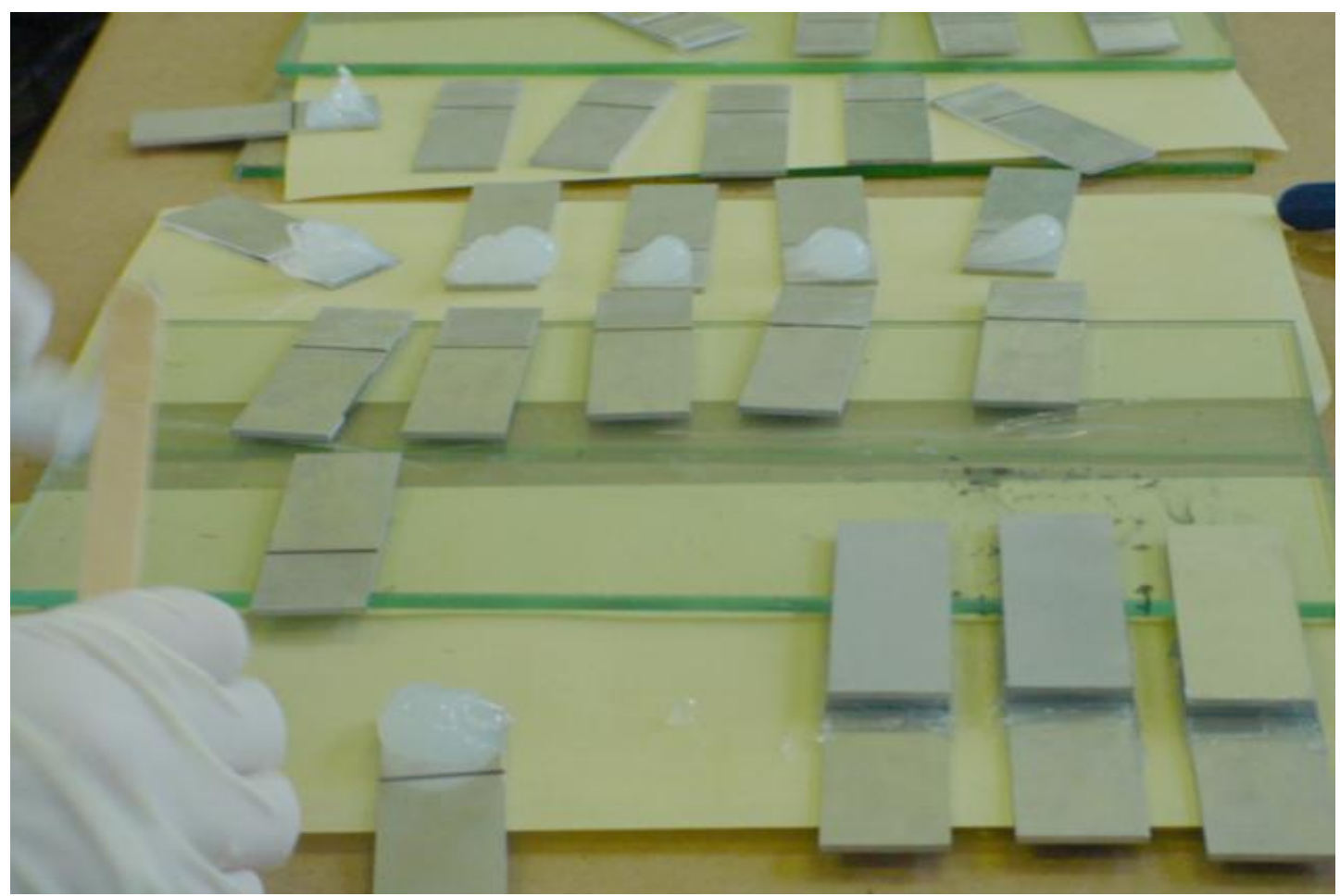

Figura 21 - Preparação dos corpos de prova de silicone, ajustando no gabarito Fonte: Laboratório da empresa Brascola 


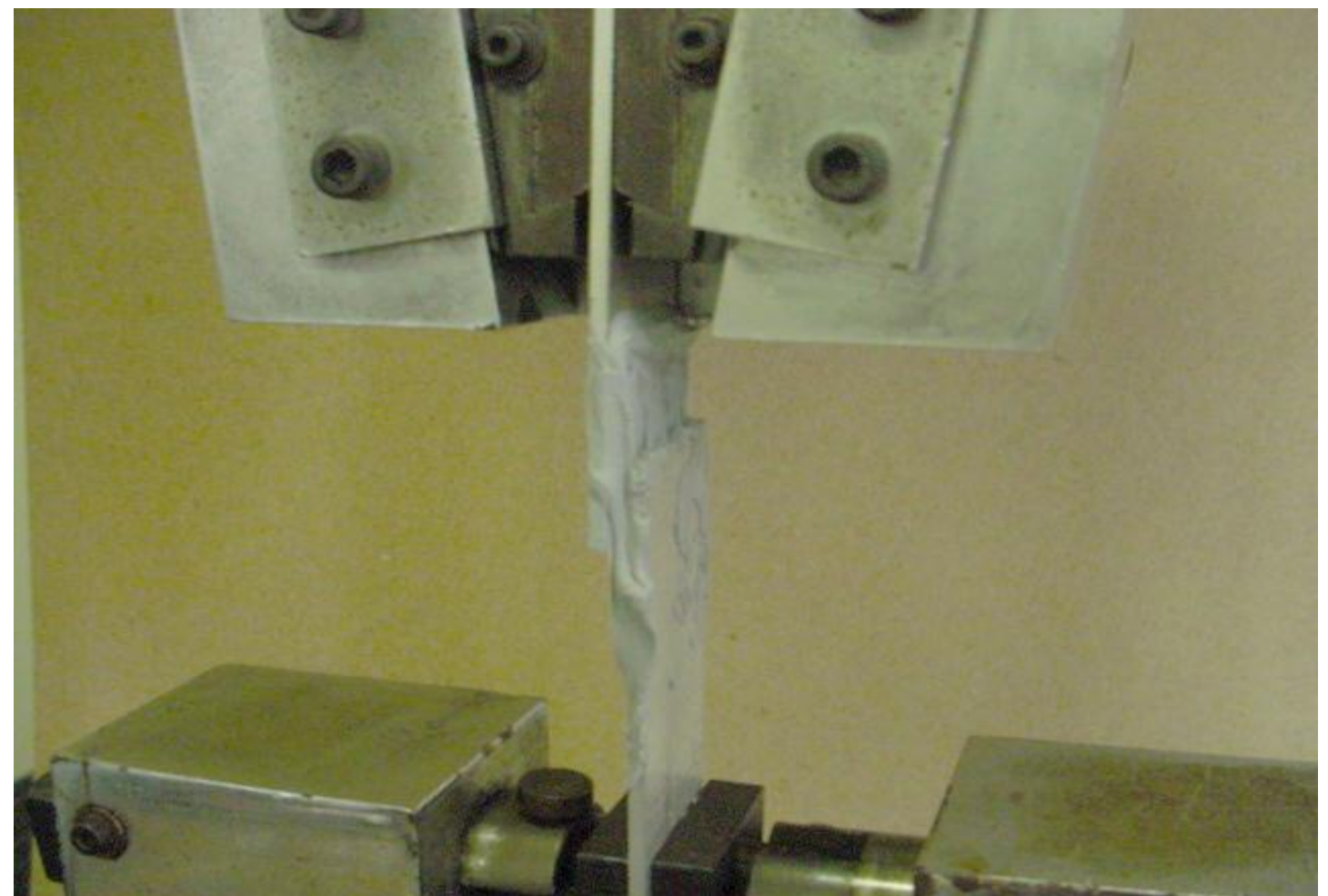

Figura 22 - Corpo de prova do mastic sendo tracionado

Fonte: Laboratório da empresa Brascola

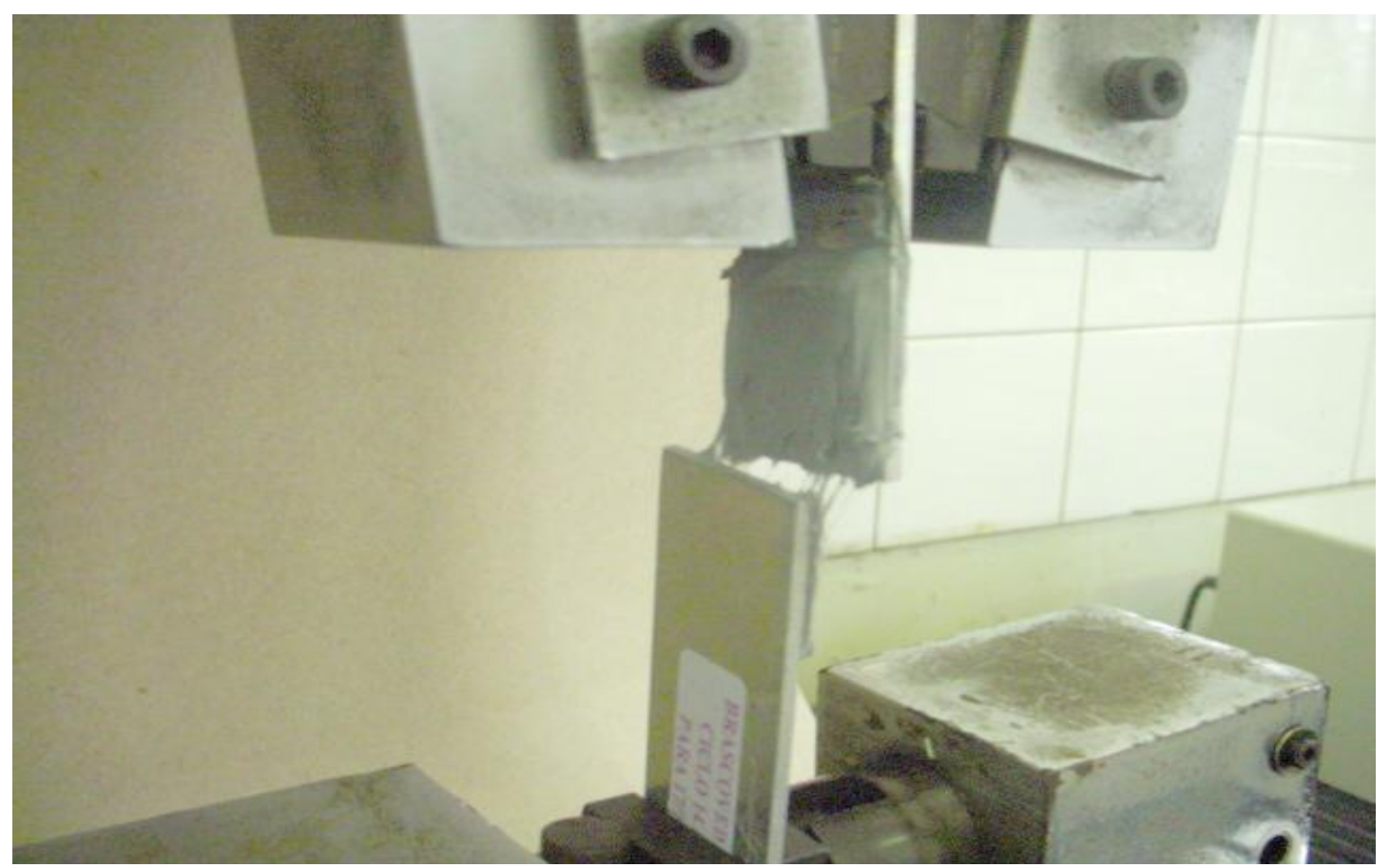

Figura 23 - Corpo de prova do mastic tracionado, até a descolagem do material Fonte: Laboratório da empresa Brascola 


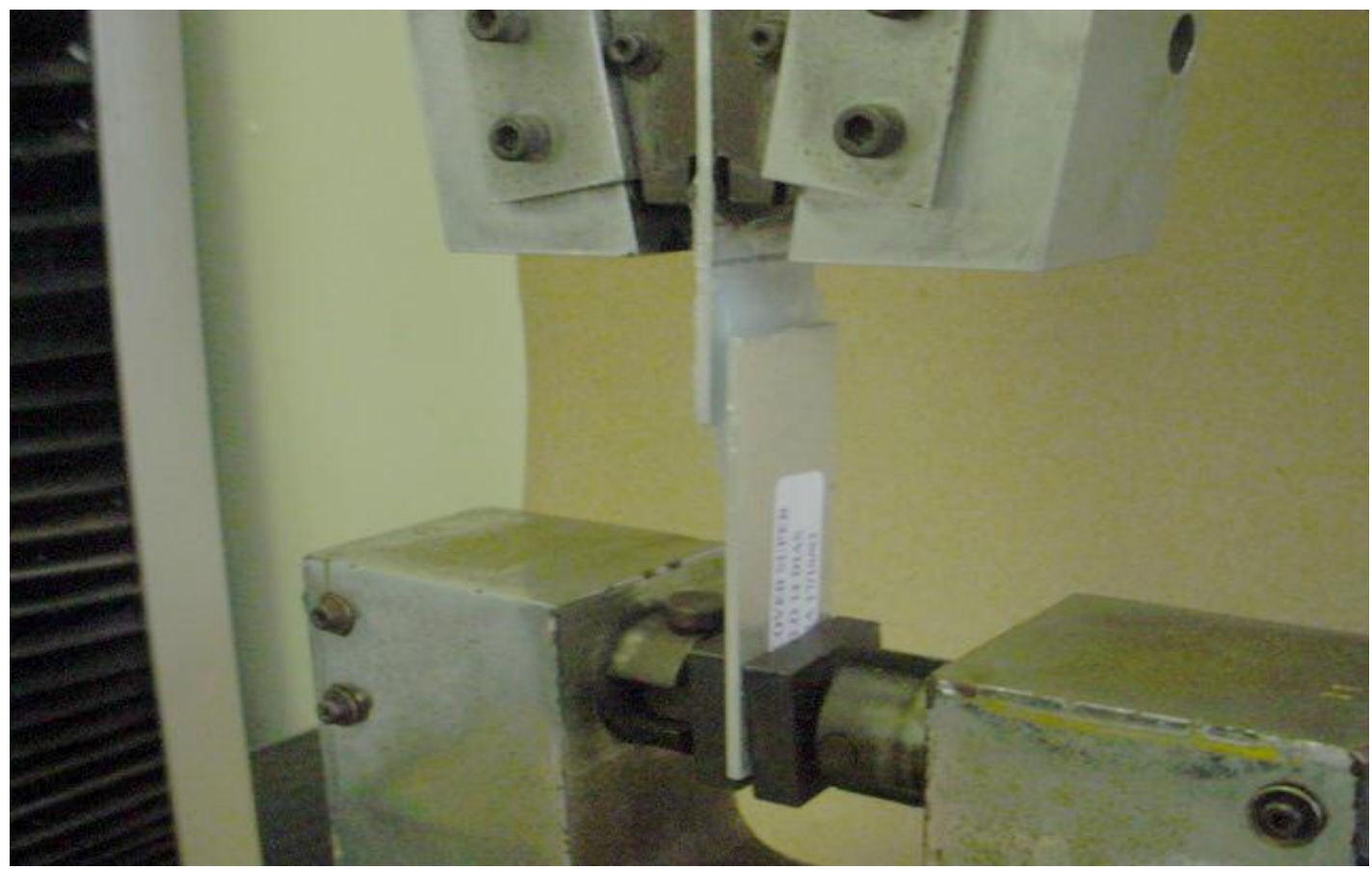

Figura 24 - Corpo de prova do silicone sendo tracionado

Fonte: Laboratório da empresa Brascola

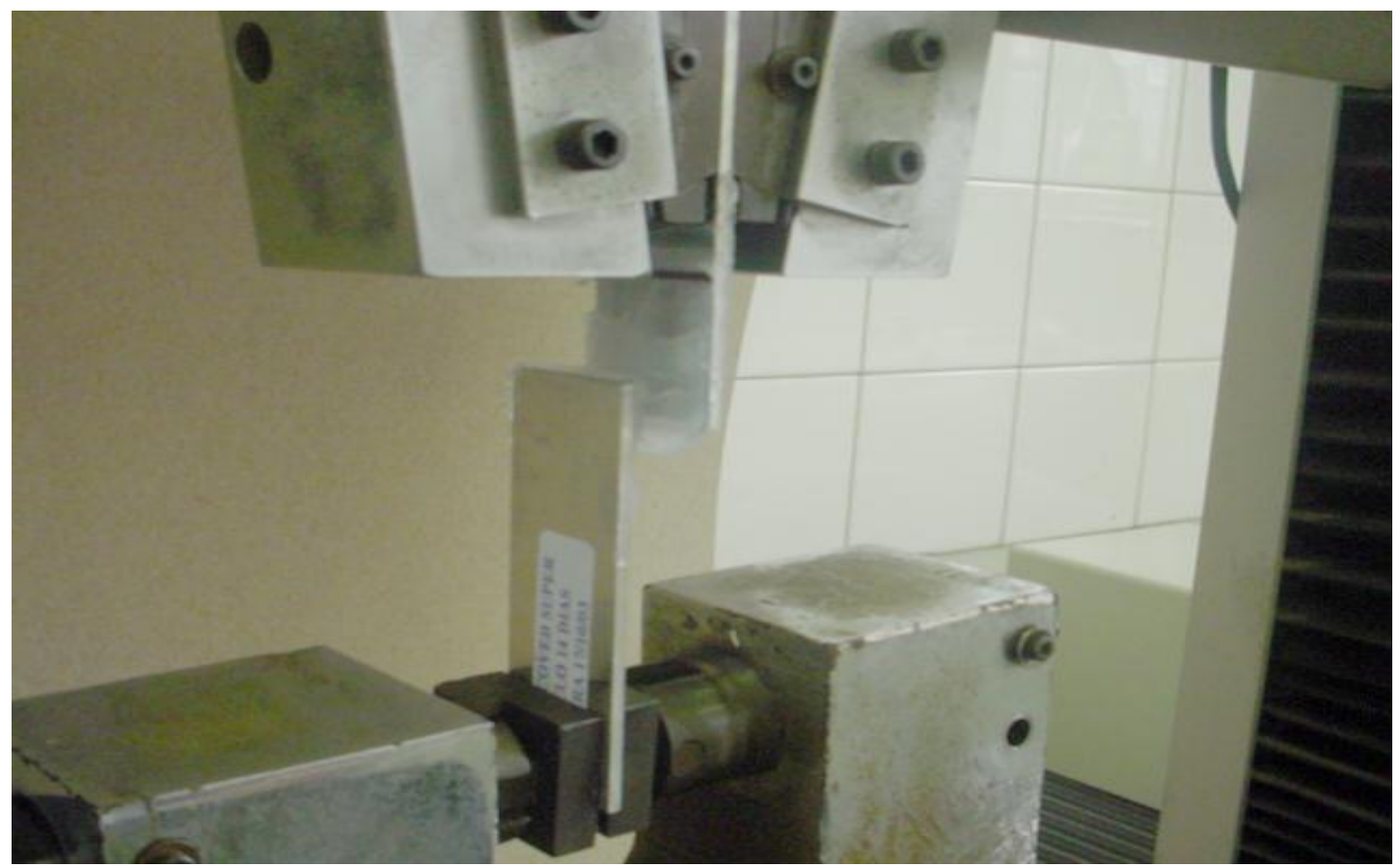

Figura 25 - Corpo de prova do silicone tracionado até a descolagem do material

Fonte: Laboratório da empresa Brascola 


\section{5 - ESPECTROSCOPIA DE INFRAVERMELHA POR TRANSFORMADA DE FOURIE (FTIR)}

A espectroscopia vibracional na região do infravermelho, particularmente, é comumente utilizada na identificação de grupos químicos orgânicos (Alinger et al., 1976).

O método baseia-se na emissão de radiação por uma fonte de infravermelho, que passa por um interferômetro, e muda seu padrão de interferência quando absorvido pela amostra. O sinal é, então, detectado e codificado através de um cálculo de Transformada de Fourier. Fortes absorções em determinadas frequências resultam dos movimentos de deformação axial e/ou angular de uma determinada ligação química. As moléculas constituem-se de diferentes tipos de átomos e ligações com forças de ligação diferentes. Portanto, combinações diferentes de massas atômicas e energias de ligação dão origem a sistemas que vibram a frequências diferentes quando a molécula absorve energia eletromagnética.

Está técnica baseia-se no fato de um feixe de luz refletido internamente pela superfície de um meio transmissor durante o processo de reflexão (Silverstein, et al., 1979).

Um material (a amostra) com índice de reflexão menor do que aquele do meio transmissor é posto em contato com a superfície refletora, a luz atravessa o material até a profundidade de alguns micrômetros, produzindo assim um espectro de absorção. Utilizaram as amostras na forma de uma lâmina com $5 \mathrm{~cm}$ de comprimento, por $1 \mathrm{~cm}$ de largura, por 2 a $5 \mathrm{~mm}$ de espessura aproximadamente, estas foram refletidas na região superficial do isolador.

O modelo do espectrofotômetro é FTIR Nicolet modelo Thermo-Nicolet Magna $560 \mathrm{com}$ capacidade de varredura de 400 a $4000 \mathrm{~cm}^{-1}$ (infravermelho médio), resolução de $4 \mathrm{~cm}^{-1}, 128$ varreduras. As análises (DRIFT) foram conduzidas em célula de refletância difusa especial (Spectra-Tech). Nesta frequência a radiação infravermelha quando absorvida, converte-se em energia de vibração molecular, sendo possível a identificação de grupos funcionais presentes na estrutura do material e o acompanhamento das modificações nas estruturas químicas dos polímeros. 


\section{6 - IRRADIAÇÃO DAS AMOSTRAS}

Neste trabalho foi utilizado um acelerador de elétrons modelo DC1500/25/4 JOB188 (Dynamitron ${ }^{\circledR}$ ), com energia de 0,5 MeV até 1,5 MeV, corrente de feixe até $25 \mathrm{~mA}$, varredura de 60 a $120 \mathrm{~cm}$, potência máxima de feixe de $37,5 \mathrm{~kW}$, variando a taxa de dose de 1,07 kGy/s até $161,67 \mathrm{kGy} / \mathrm{s}$, no qual as amostras foram irradiadas com as doses de radiação de 5, 10, 20 e $30 \mathrm{kGy}$, utilizando uma taxa de dose de 22,61 kGy/s. O experimento foi limitado a $30 \mathrm{kGy}$, pois acima deste valor seria economicamente inviável. As amostras foram irradiadas perpendicularmente à superfície do alumínio. A faixa de energia de elétrons foi escolhida para permitir a máxima penetração do feixe de elétrons através das placas de alumínio, pois nesta região o poder de penetração no alumínio é minimizado $(1,5 \mathrm{MeV} \mathrm{cm} / \mathrm{g})$. Assim, os elétrons atingem a camada de mastic nas amostras. A irradiação foi realizada no ar. O equipamento pertence ao IPEN (Instituto Pesquisas Energéticas e Nucleares) onde foram irradiados os corpos de provas das amostras. Todos os corpos de provas tanto do mastic como do silicone foram preparados em um recipiente cilíndrico com as seguintes dimensões: diâmetro de $60 \mathrm{~mm}$ e altura de $7 \mathrm{~mm}$, aqui denominados de "cilindros", conforme a Figura 26, e irradiadas após 28 dias de aplicadas para 0 ensaio de DSC. No ensaio de tensão de cisalhamento foram preparados corpos de prova conforme descrito no item 3.1.4.

As amostras após as doses de radiação aguardaram 48 horas para serem submetidas aos ensaios de DSC e tensão de cisalhamento. 


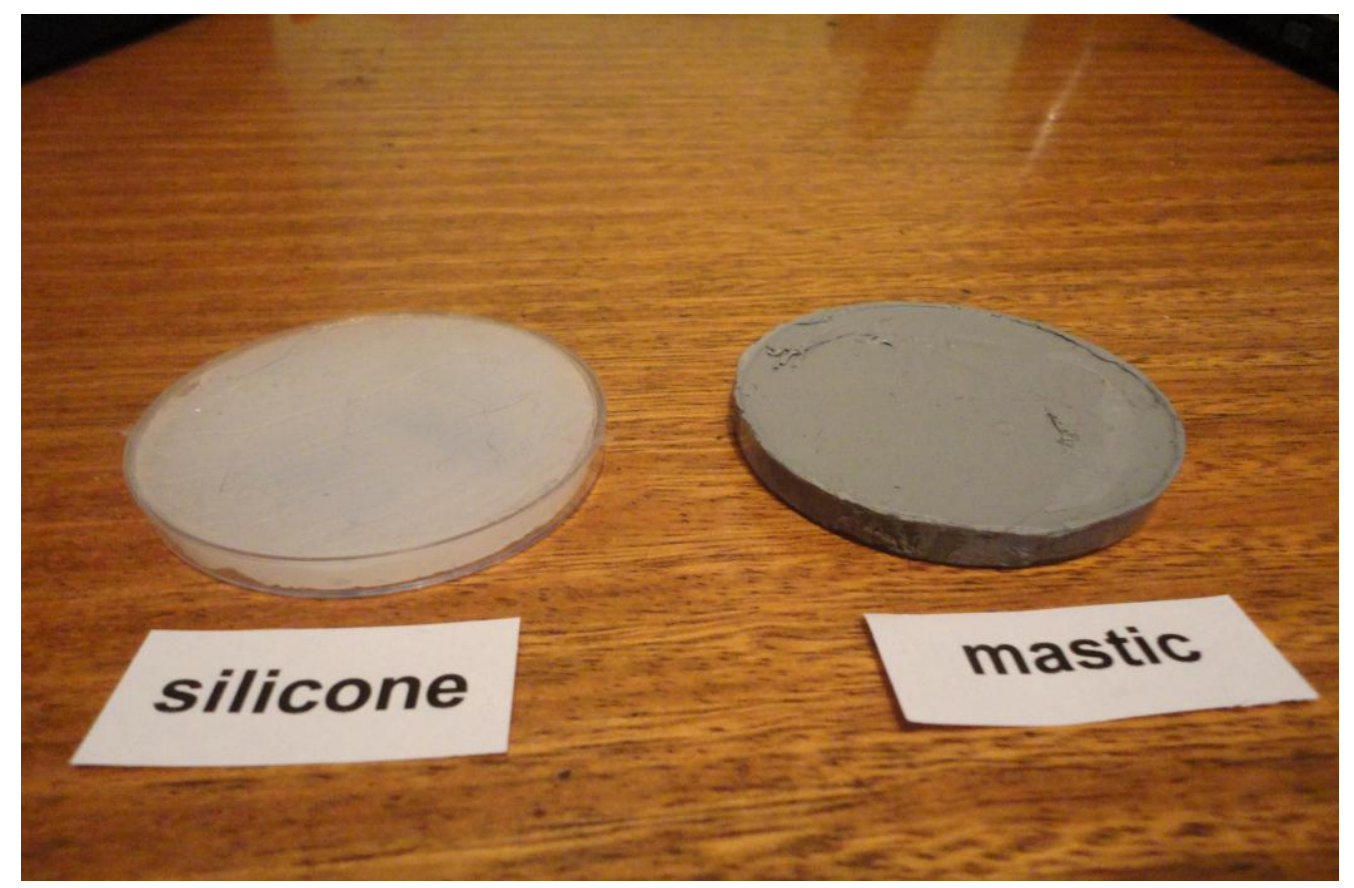

Figura 26 - Corpos de prova (cilindros) mastic e silicone, após 28 dias de aplicado

Fonte: Laboratório da empresa Brascola 


\section{RESULTADOS E DISCUSSÃO}

Os resultados do ensaio de alongamento e ruptura foram obtidos pela norma ASTM D 412 (2002), no entanto, não foi possível realizar os ensaios do mastic, a amostra não apresentou condições para realização do ensaio, comprometendo assim os resultados, conforme mostrado nas Figuras de 15 a 17, no item 3.1. Desta maneira os ensaios de alongamento e ruptura não foram realizados na amostra de mastic, devido a não apresentar condições de montar o corpo de prova para o ensaio. Na Tabela 5 são colocados os valores de alongamento e ruptura do silicone que foram possíveis em razão da cura, e consistência ao término de sua cura.

\section{Tabela 5 - Ensaios de alongamanto e resistência à tração na ruptura do silicone}

\begin{tabular}{lccccccc}
\hline \multicolumn{1}{c}{ amostras de silicone } & 1 & 2 & 3 & 4 & 5 & média & Desvio padrão \\
\hline Módulo de Alongamento a 100\% & 0,52 & 0,53 & 0,51 & 0,52 & 0,51 & 0,52 & 0,01 \\
Resistência à Tração (N/mm²) & 2,80 & 2,78 & 2,77 & 2,81 & 2,81 & 2,79 & 0,02 \\
Resistência à Tração (psi) & 406,11 & 403,20 & 401,75 & 407,56 & 407,56 & 405,24 & 2,63 \\
& & & & & & & \\
Limite de Resistência (kgf/cm²) & 28,55 & 28,35 & 28,25 & 28,65 & 28,65 & 28,49 & 0,19 \\
\hline Fonte: Laboratório da empresa Brascola & & & & & &
\end{tabular}

Os resultados do ensaio de grau de reticulação foram obtidos conforme a norma ASTM D 2765 Determination of Gel Content and Swell Ratio of Crosslinked Ethylene Plastics (1995), como apresentado na Tabela 6, onde tem-se o comportamento das amostras de mastic e silicone quanto à reticulação de seus respectivos sistemas nos ciclos de 7, 14 e 28 dias. No entanto não foi possível realizar este ensaio com as amostras irradiadas. 
Tabela 6: Grau de reticulação do mastic e do silicone

\begin{tabular}{cccc}
\hline DIAS & MASTIC (\%) & SILICONE (\%) & OBSERVAÇõES \\
\hline 7 & 46,82 & 68,71 & mastic em forma de pó \\
14 & 64,21 & 72,09 & mastic em forma de pó \\
28 & 48,32 & 74,76 & mastic em forma de pó \\
MÉDIA & 53,12 & 71,85 & \\
\hline
\end{tabular}

Fonte: Silva, et al., (2003)

O sistema mastic após o contato com o solvente, produz um resíduo final que se transforma em um pó muito fino. Os cálculos de determinação do grau de reticulação foram realizados pesando-se este resíduo (Silva et al., 2003). Nesta amostra não houve a presença de formação de gel, que caracterizaria o sistema de cura ou reticulação do polímero butil que é a matriz polímerica do mastic. O valor médio de 53,12\% representa a quantidade de carbonato de cálcio precipitado presente na amostra, conforme informado pelo fabricante do produto (Brascola). Enquanto que no silicone o grau de reticulação médio foi de $71,85 \%$, apresentando a formação de um polímero no estado de gel que caracterizou a cura deste sistema. Portanto o mastic não apresenta um sistema de cura como ocorre com o sistema silicone. Neste ensaio não foi possível submeter os resíduos a radiação ionizante.

Os resultados do ensaio de calorimetria exploratória diferencial (DSC) foram obtidos conforme a norma ASTM D 3418 - Transition temperatures of polymers by thermal analysis (1982). Tanto na amostra de silicone como na do mastic. No relatório de Silva et al., (2003) apresentam-se os resultados tanto do silicone como do mastic sem a presença da radiação ionizante. Nas Figuras de 27 a 36 pode-se observar o comportamento das amostras de silicone e mastic sem e com radiação ionizante. 
DSC

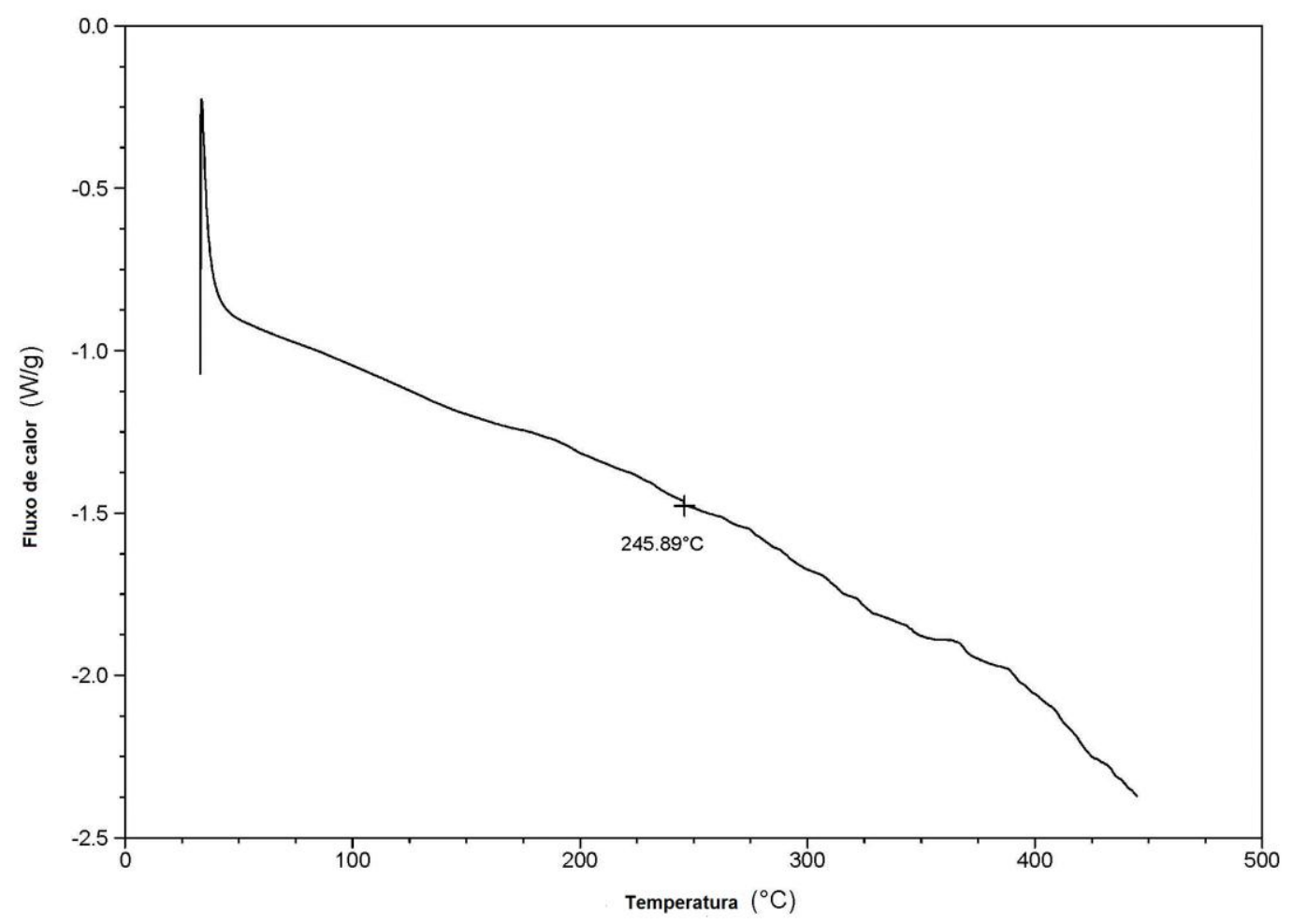

Figura 27: Curva DSC da amostra de silicone sem radiação ionizante

Na Figura 27 na curva de DSC obtida com a amostra de silicone (sem radiação ionizante) não são observadas transições com variação de entalpia, indicando caráter inerte ou não reativo da amostra. Apresenta uma pequena perda de massa a $245,59^{\circ} \mathrm{C}$, proveniente do polibuteno presente na formulação conforme informado pelo fabricante. 
DSC

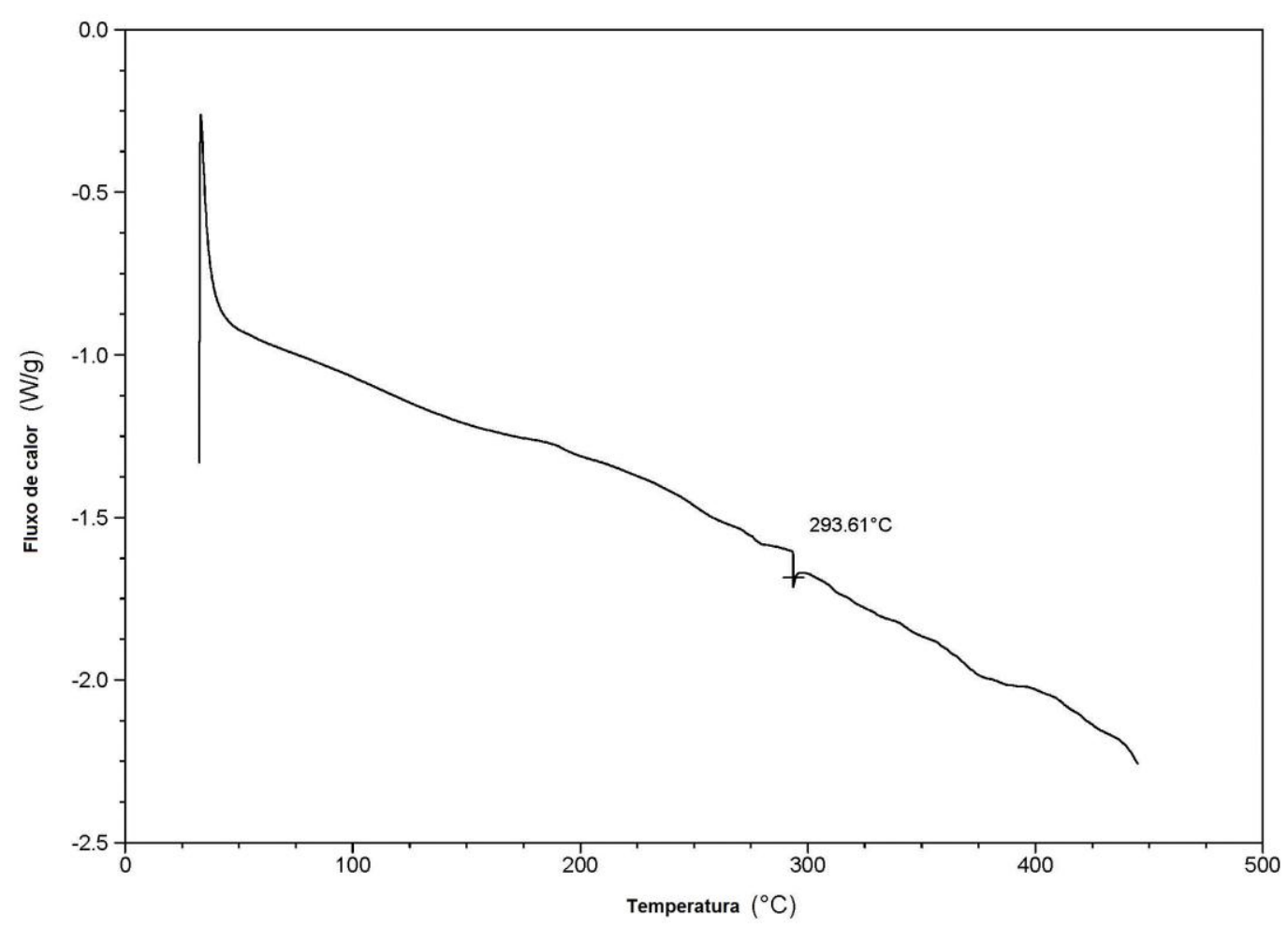

Figura 28: Curva DSC da amostra de silicone com dose de radiação de 5 kGy

Na Figura 28, a curva de DSC obtida com a amostra de silicone não são observadas transições com variação de entalpia, indicando caráter inerte ou não reativo da amostra, mesmo sendo submetida a radiação ionizante de 5 kGy. Apresenta uma pequena perda de massa a $293,61^{\circ} \mathrm{C}$, proveniente do polibuteno presente na formulação conforme informado pelo fabricante. 
DSC

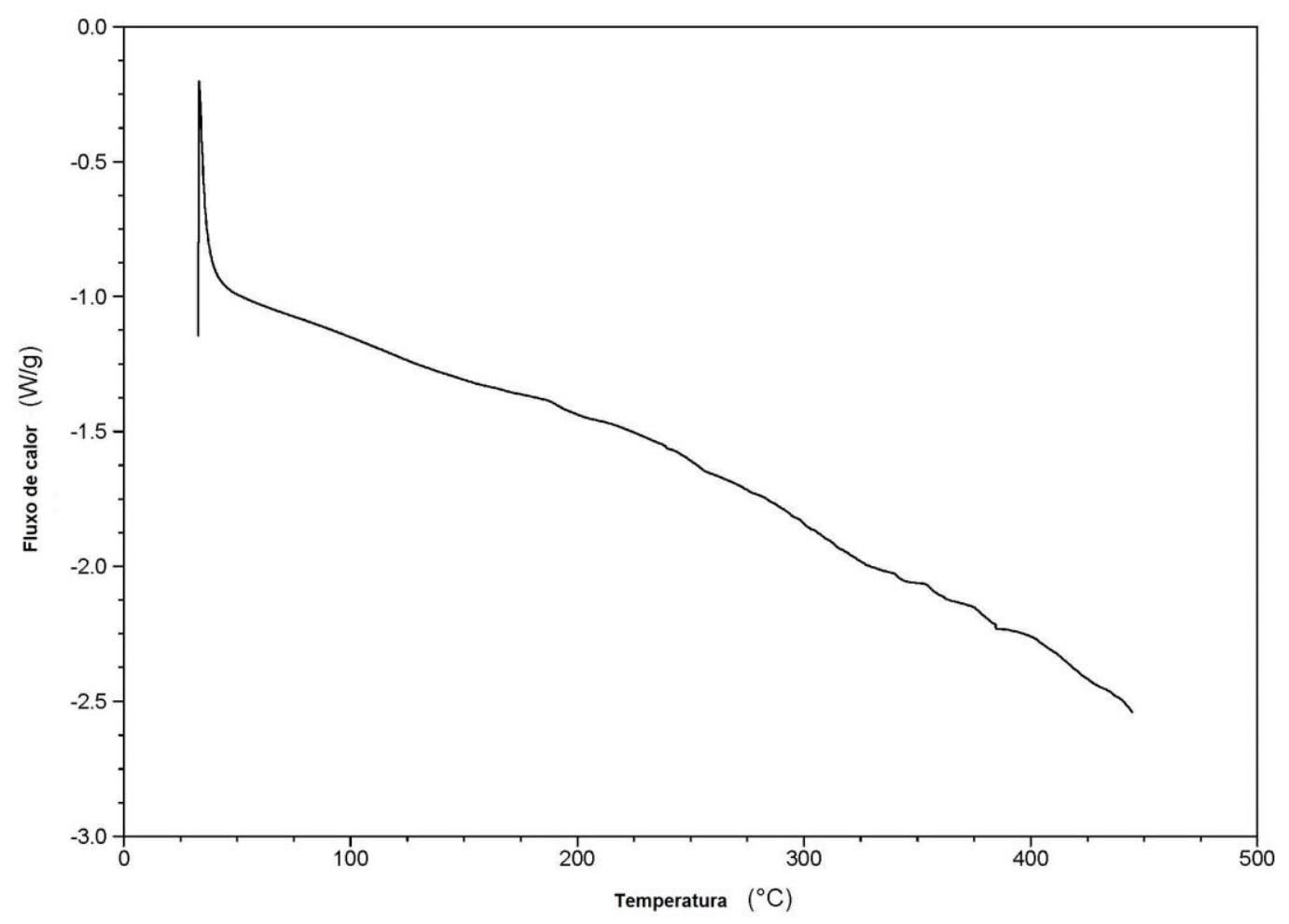

Figura 29: Curva DSC da amostra de silicone com dose de radiação de 10 kGy

Na Figura 29, a curva de DSC obtida com a amostra de silicone não são observadas transições com variação de entalpia, indicando caráter inerte ou não reativo da amostra, mesmo sendo submetida a uma radiação ionizante de 10 kGy. 
DSC

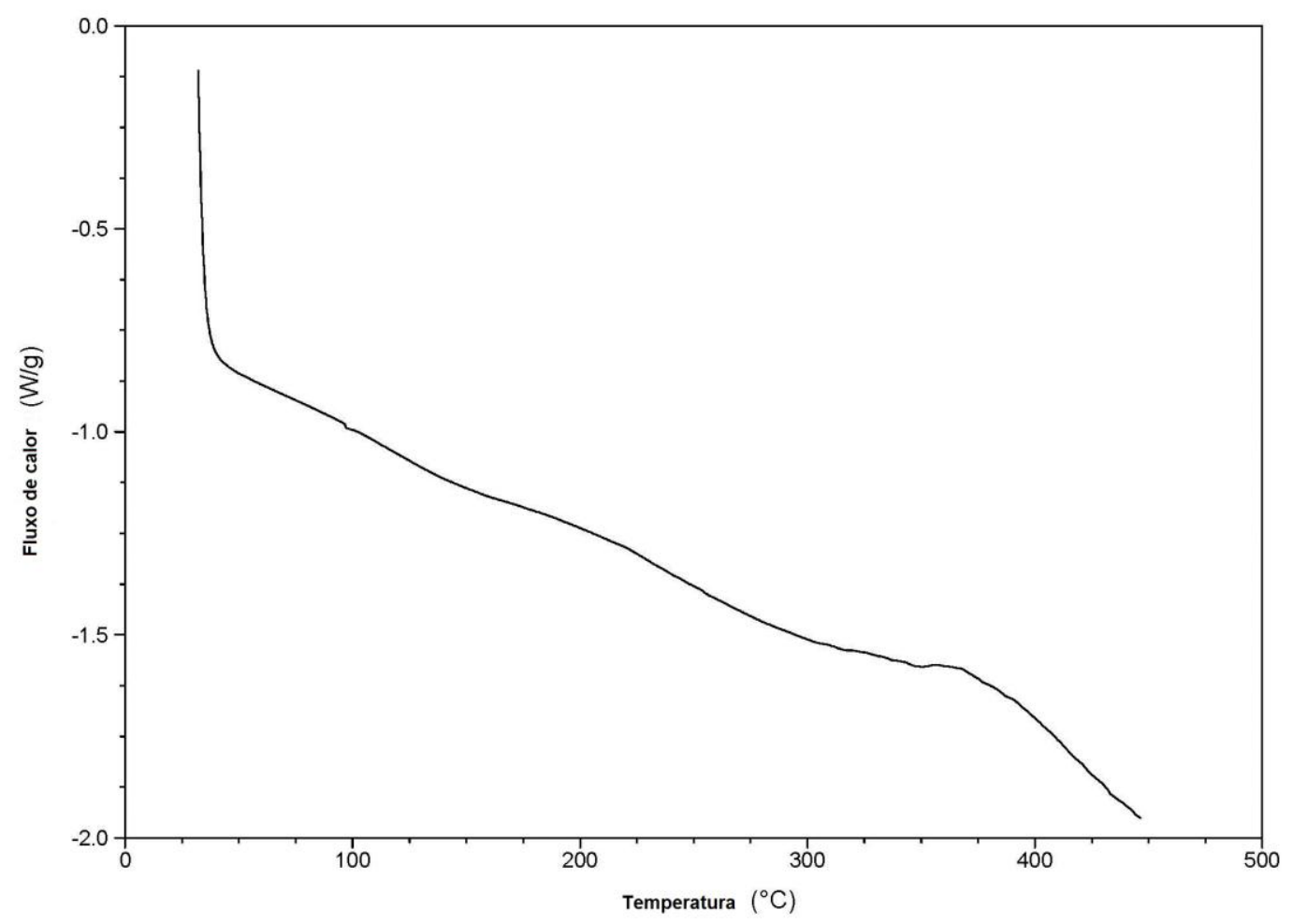

Figura 30: Curva DSC da amostra de silicone com dose de radiação de 20 kGy

Na Figura 30, a curva de DSC obtida com a amostra de silicone não são observadas transições com variação de entalpia, indicando caráter inerte ou não reativo da amostra, mesmo sendo submetida a uma radiação ionizante de 20 kGy. 
DSC

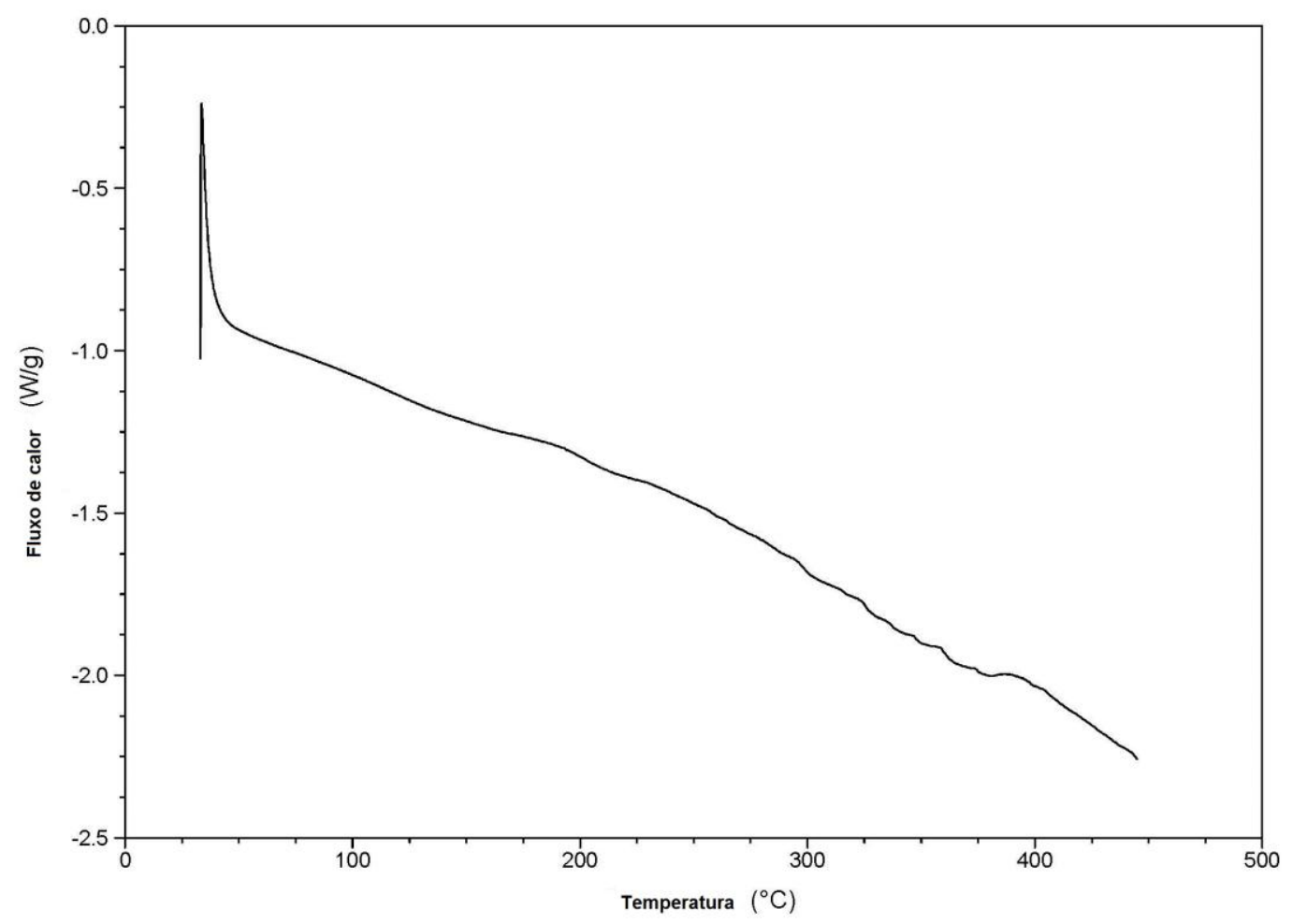

Figura 31: Curva DSC da amostra de silicone com dose de radiação de 30 kGy

Na Figura 31, a curva de DSC obtida com a amostra de silicone não são observadas transições com variação de entalpia, indicando caráter inerte ou não reativo da amostra, mesmo sendo submetida a uma radiação ionizante de 30 kGy. 
DSC

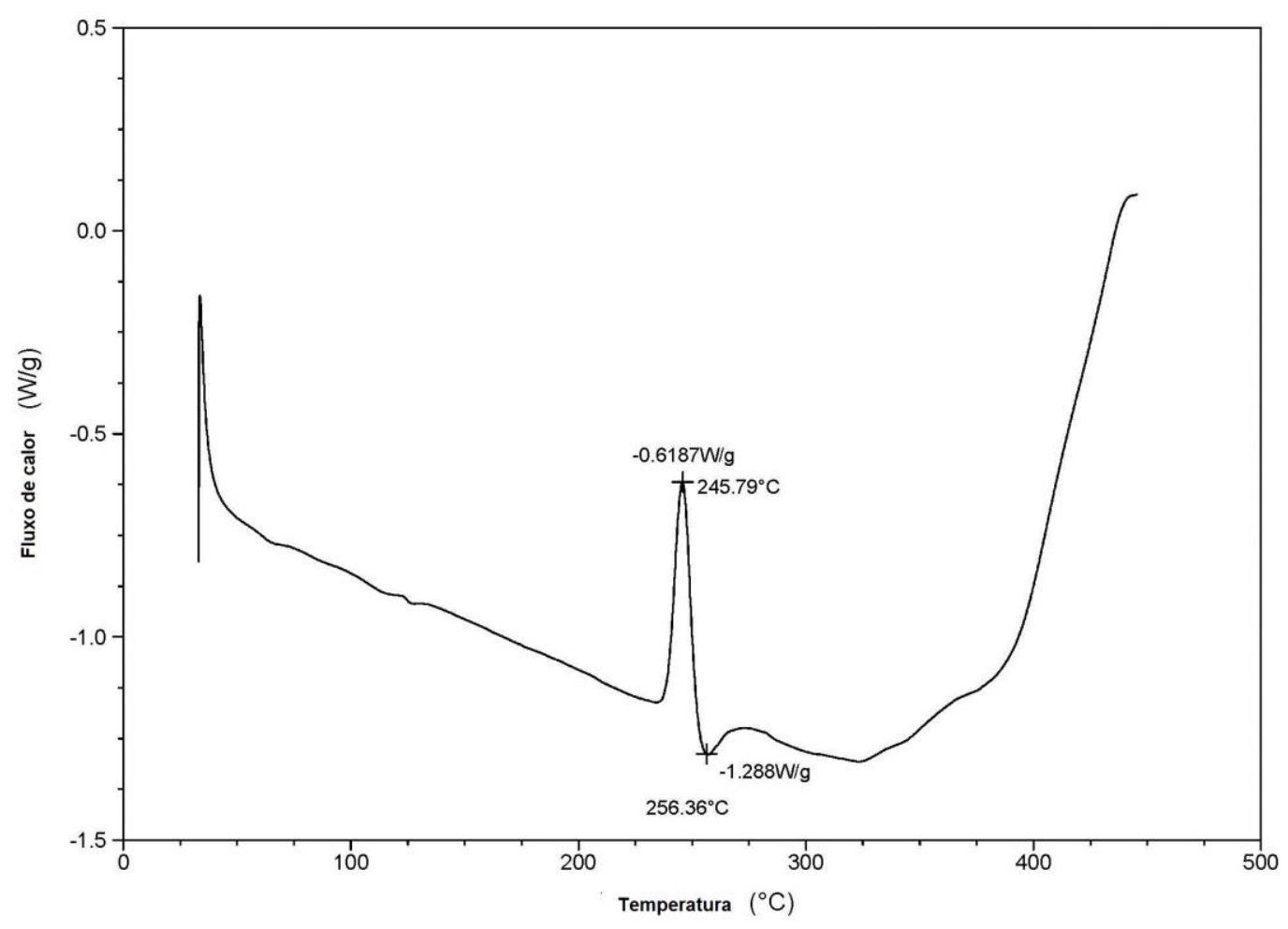

Figura 32: Curva DSC da amostra de mastic sem radiação ionizante

Na Figura 32, a curva de DSC obtida com a amostra de mastic (sem radiação ionizante) mostra um pico exotérmico entre 230 e $280^{\circ} \mathrm{C}$. O pico alongado que se observa a partir desta temperatura pode estar associado a um evento de degradação oxidativa do butil na amostra e também ocorre simultaneamente uma significativa perda de massa. 


\section{DSC}

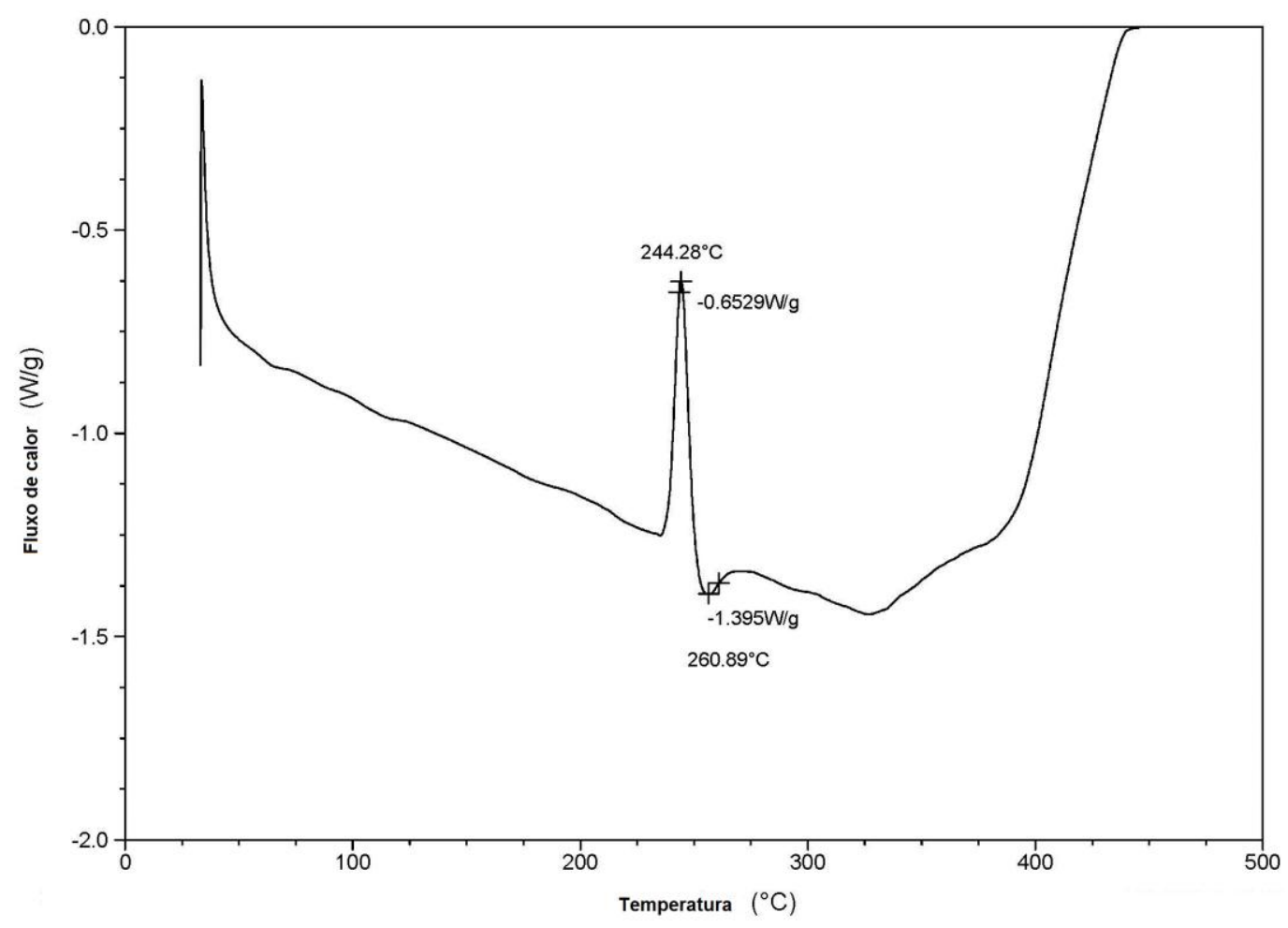

Figura 33: Curva DSC da amostra de mastic com dose de radiação de 5 kGy

Na Figura 33, a curva de DSC obtida com a amostra de mastic com uma radiação de $5 \mathrm{kGy}$, mostra um pico de reação química exotérmica entre $230 \mathrm{e}$ $280^{\circ} \mathrm{C}$. O pico alongado que se observa a partir desta temperatura pode estar associado a um evento de degradação oxidativa do butil na amostra e também ocorre simultaneamente uma significativa perda de massa. 
DSC

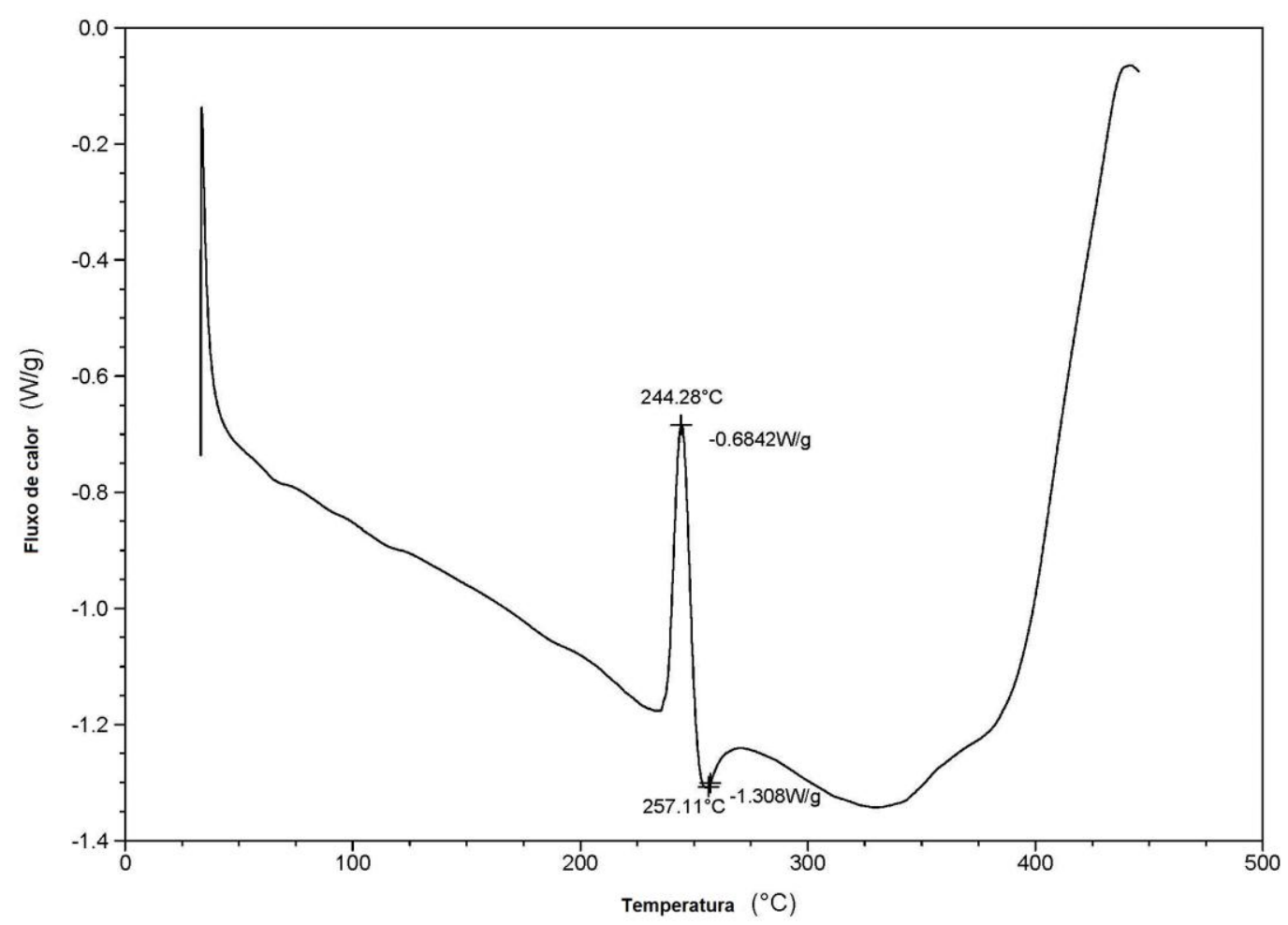

Figura 34: Curva DSC da amostra de mastic com dose de radiação de 10 kGy

Na Figura 34, a curva de DSC obtida com a amostra de mastic com uma radiação de 10 kGy, mostra um pico de reação química exotérmica entre 230 e $280^{\circ} \mathrm{C}$. O pico alongado que se observa a partir desta temperatura pode estar associado a um evento de degradação oxidativa do butil na amostra e também ocorre simultaneamente uma significativa perda de massa. 
DSC

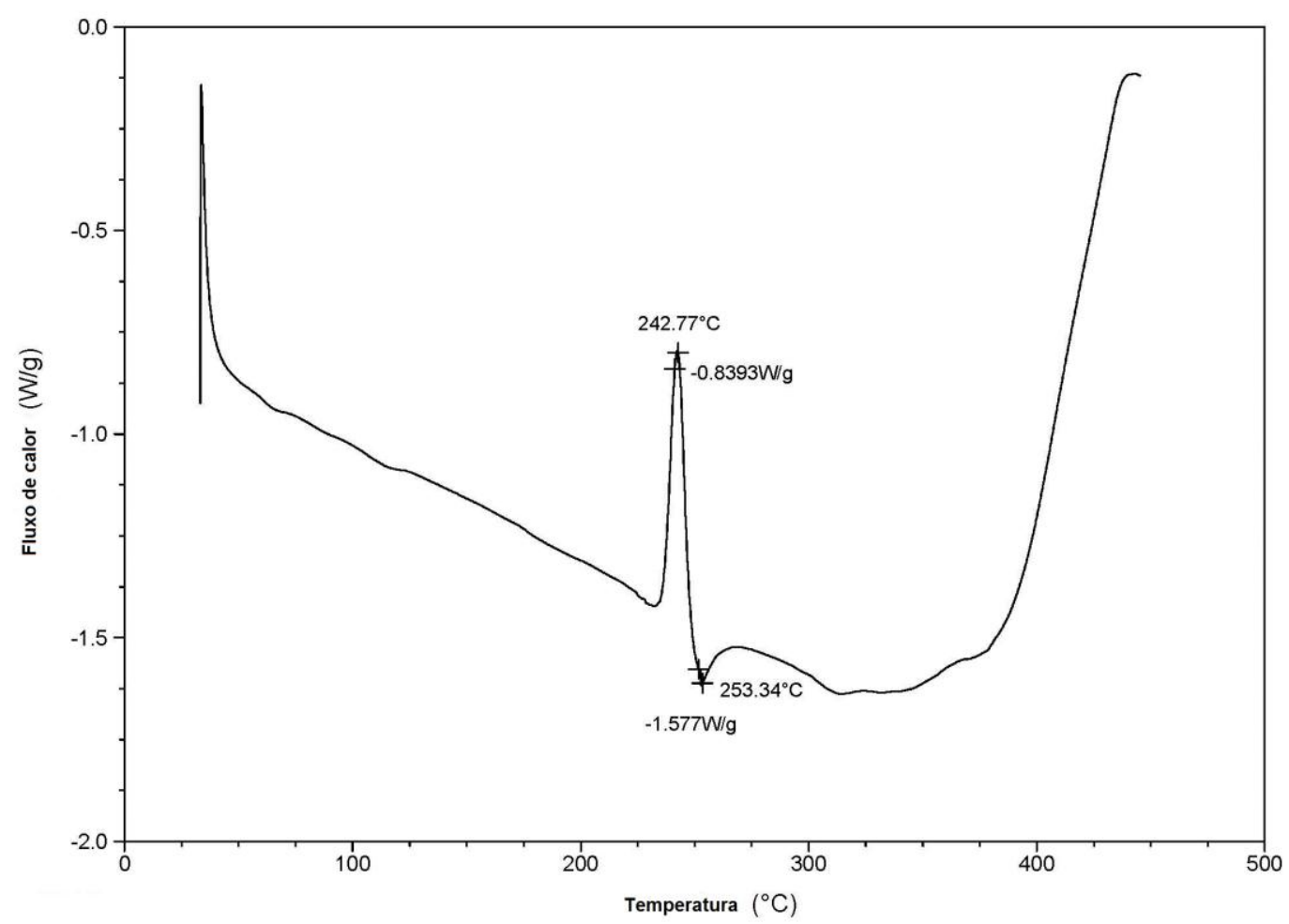

Figura 35: Curva DSC da amostra de mastic com dose de radiação de 20 kGy

Na Figura 35, a curva de DSC obtida com a amostra de mastic com uma radiação de 20 kGy, mostra um pico de reação química exotérmica entre 230 e $280^{\circ} \mathrm{C}$. O pico alongado que se observa a partir desta temperatura pode estar associado a um evento de degradação oxidativa do butil na amostra e também ocorre simultaneamente uma significativa perda de massa. 


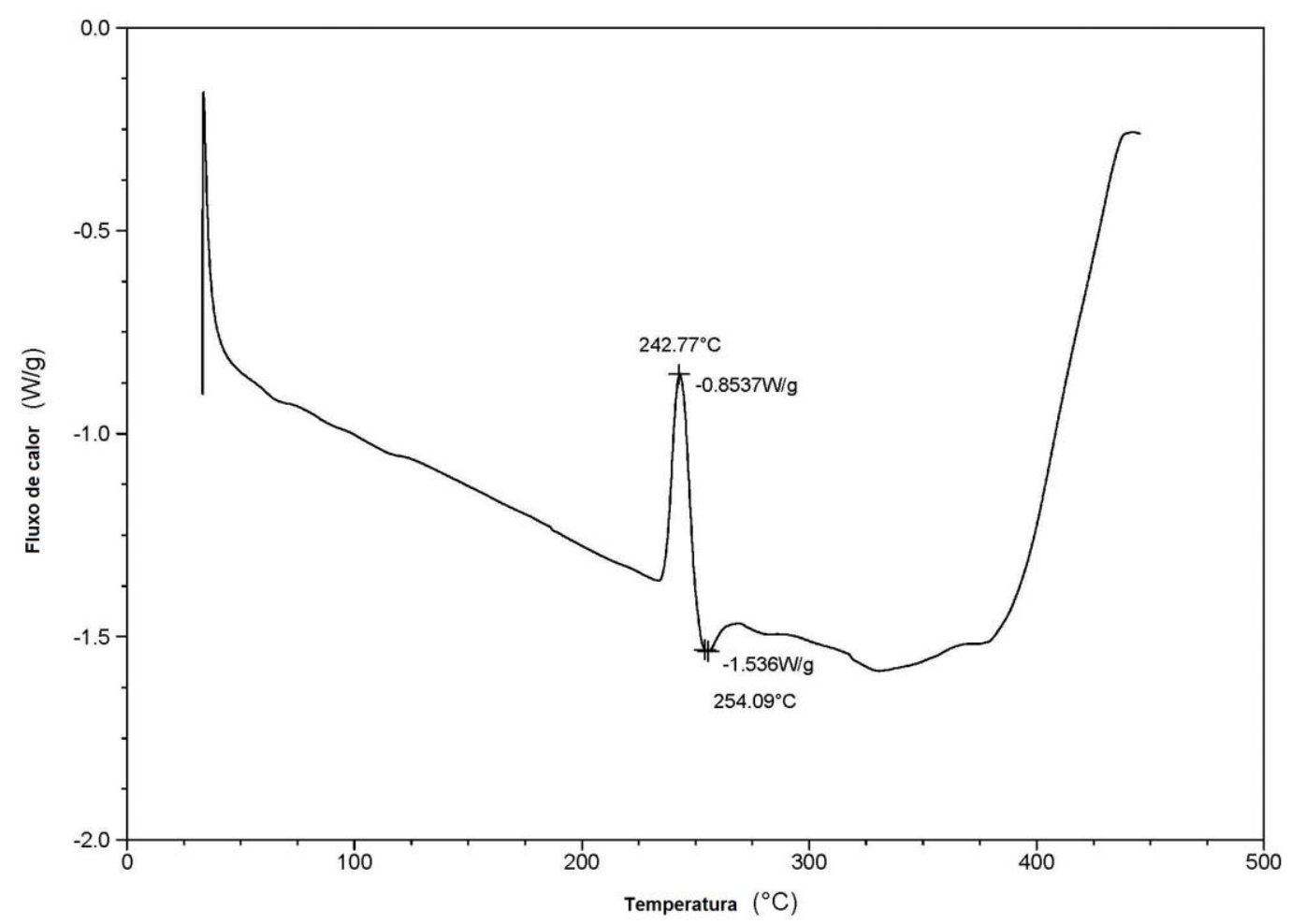

Figura 36: Curva DSC da amostra de mastic com dose de radiação de 30 kGy

Na Figura 36, a curva de DSC obtida com a amostra de mastic com uma radiação de $30 \mathrm{kGy}$, mostra um pico de reação química exotérmica entre $230 \mathrm{e}$ $280^{\circ} \mathrm{C}$. O pico alongado que se observa a partir desta temperatura pode estar associado a um evento de degradação oxidativa do butil na amostra e também ocorre simultaneamente uma significativa perda de massa.

Pode-se observar que neste ensaio, independente da dose de radiação ionizante ou mesmo na sua ausência, tanto o silicone como o mastic não apresentaram resultados divergentes entre as duas situações com relação a análise térmica.

Os resultados do ensaio da tensão de cisalhamento foram obtidos conforme a norma ASTM D 1002 (2001), embora a norma peça 5 corpos de prova por amostra, foram realizados 10 corpos de prova para visualizar melhor os resultados do ensaio. Estes ensaios foram realizados sem exposição à radiação ionizante, com os ciclos de 7, 14 e 28 dias após a sua aplicação. As amostras 
foram divididas em dois blocos de análises, sendo um sem a radiação ionizante e o outro após exposição à radiação ionizante. As amostras foram submetidas as doses de 5, 10, 20 e 30 kGy no acelerador de elétrons Dynamitron $\AA$, conforme já descrito no item 3.2. Após 48 horas do final da irradiação as amostras foram submetidas ao ensaio de tensão de cisalhamento. As Figuras de 37 a 40 representam o comportamento das amostras citadas sem radiação ionizante e com radiação ionizante.

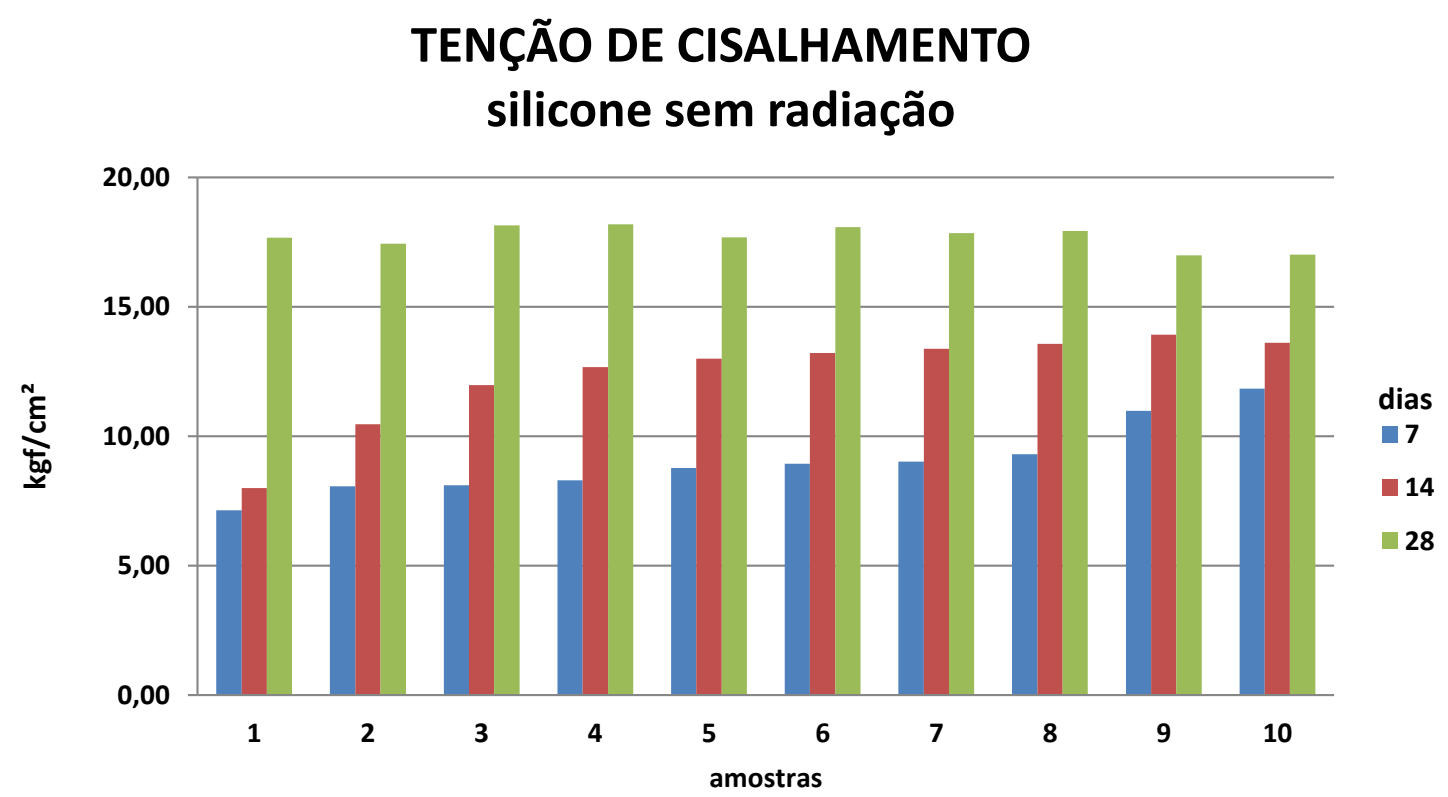

Figura 37: Tensão de cisalhamento do silicone, sem radiação nos ciclos de 7, 14 e 28 dias após a aplicação

$\mathrm{Na}$ Figura 37 pode-se observar que as tensões de cisalhamento do silicone, após 28 dias de aplicado, estão na faixa de 15 a $20 \mathrm{kgf} / \mathrm{cm}^{2}$. 


\section{TENSÃO DE CISALHAMENTO mastic sem radiação}

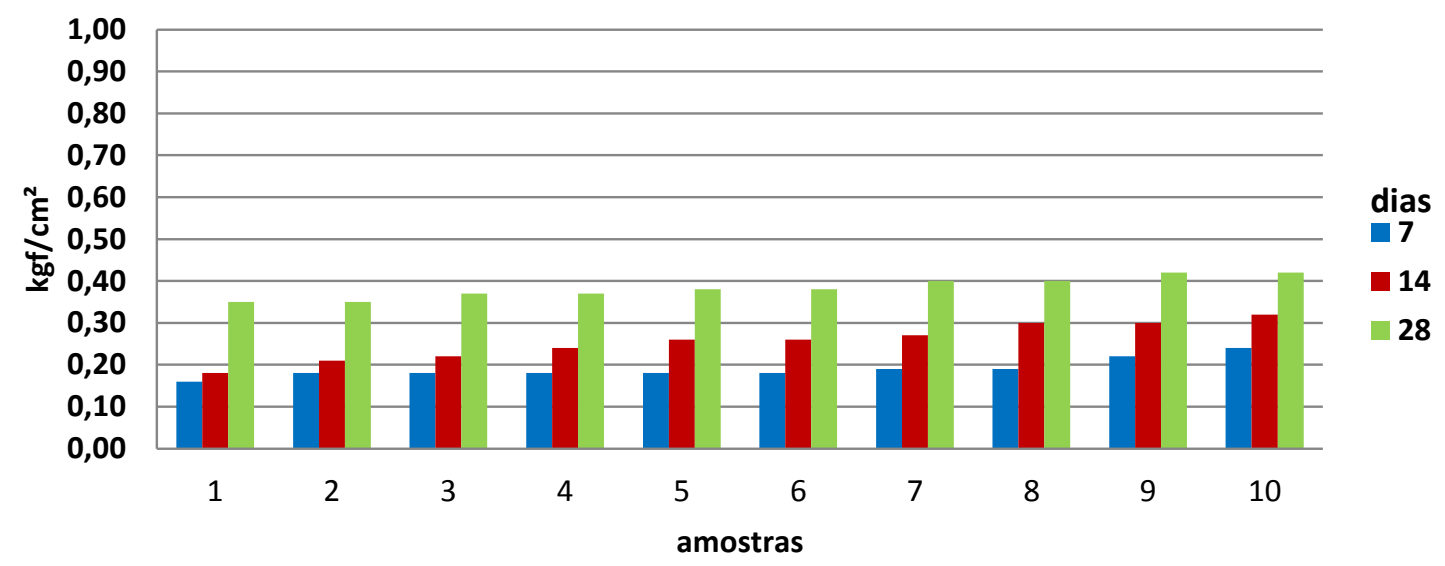

Figura 38: Tensão de cisalhamento do mastic, sem radiação nos ciclos de 7, 14 e 28 dias

$\mathrm{Na}$ Figura 38 pode-se observar que as tensões de cisalhamento do mastic, após 28 dias de aplicado, estão na faixa de 0,2 a $1,0 \mathrm{kgf} / \mathrm{cm}^{2}$. Um valor muito baixo comparado com os do silicone que esta na faixa de 15 a $20 \mathrm{kgf} / \mathrm{cm}^{2}$, conforme a Figura 37. 


\section{TENSÃO DE CISALHAMENTO silicone com radiação}

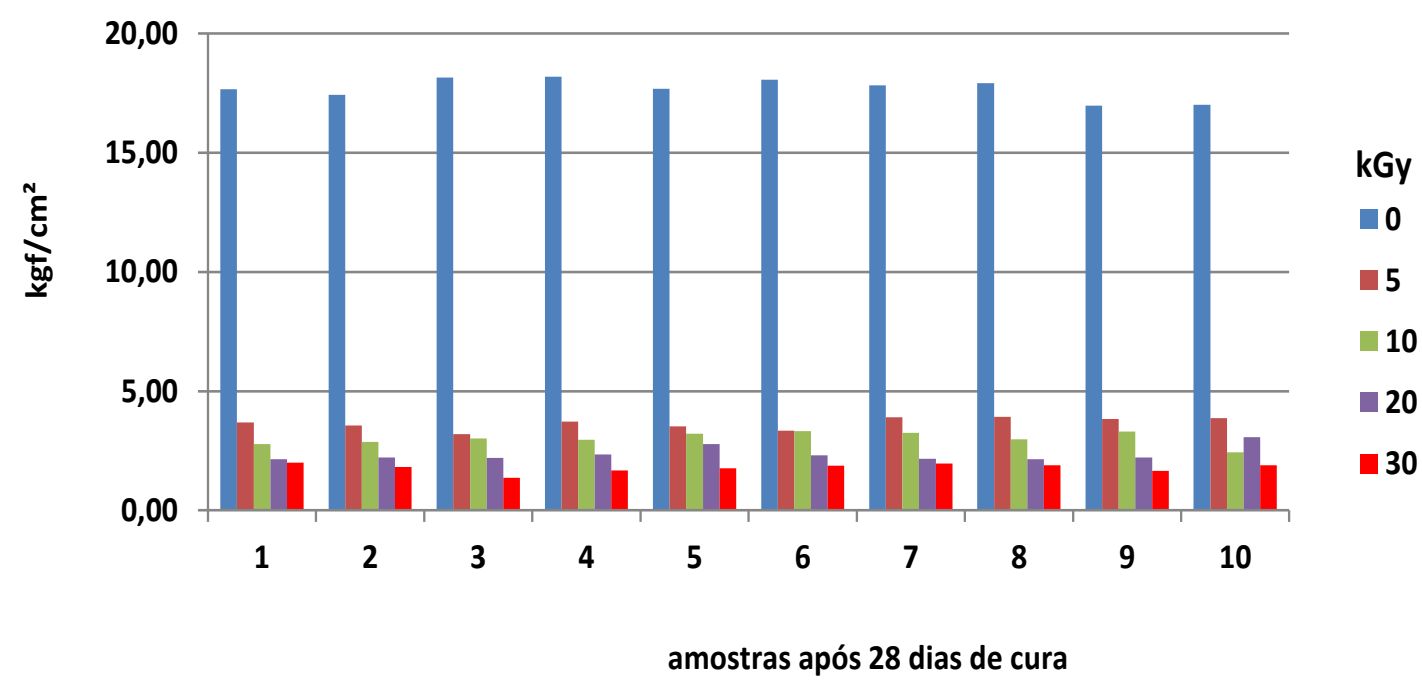

Figura 39: Tensão de cisalhamento do silicone com doses de radiação após 28 dias de cura permanecem na faixa de $5 \mathrm{~kg} / \mathrm{cm}^{2}$

$\mathrm{Na}$ Figura 39 pode-se observar a nítida queda das tensões de cisalhamento em função das doses de radiação ionizante que as amostras de silicone apresentaram (faixa, 1 a $5 \mathrm{kgf} / \mathrm{cm}^{2}$ ). Esta queda acentuada esta atrelada a quebra das ligações poliméricas do silicone, indicando uma degradação pela radiação ionizante. 


\section{TENSÃO DE CISALHAMENTO mastic com radiação}

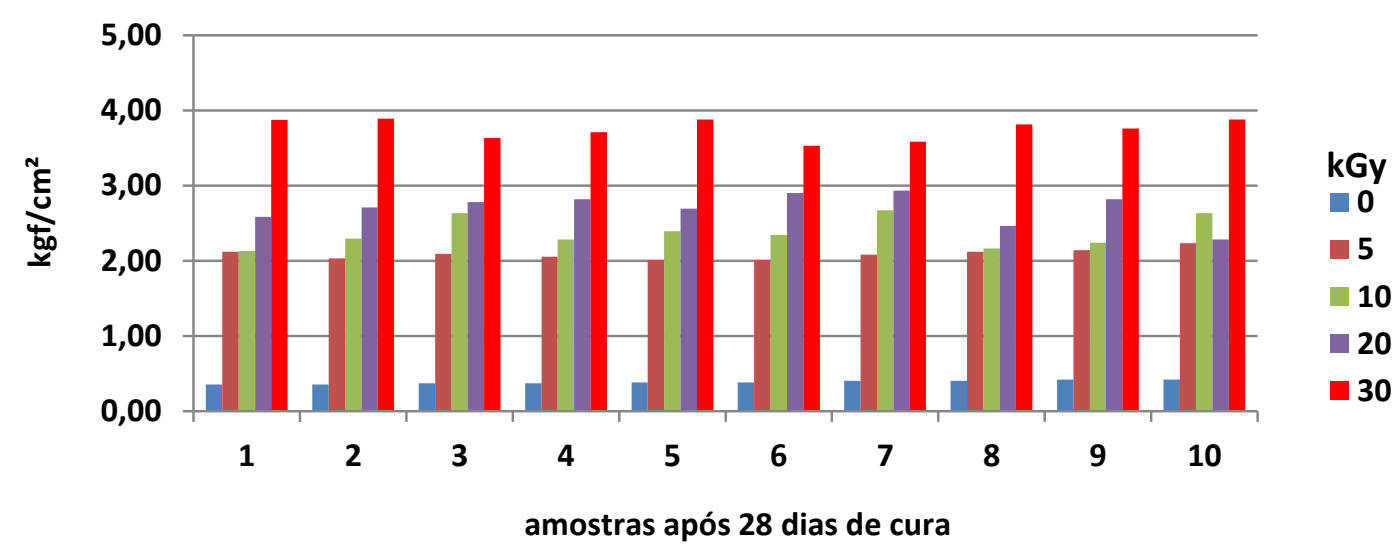

Figura 40: Tensão de cisalhamento do mastic com radiação após 28 dias de cura apresentando tensões na faixa de 3 a $4 \mathrm{kgf} / \mathrm{cm}^{2}$

Na Figura 40 é nítido o aumento das tensões de cisalhamento quando se comparam os valores das amostras sem radiação ionizante com as que foram expostas à radiação. $\mathrm{O}$ aumento nas tensões de cisalhamento este diretamente relacionado com as ligações de reticulação que o polímero butil apresenta quando exposto a esta condição.

Nas Figuras de 41 a 50 é uma sequência onde se pode observar o comportamento das tensões por amostra em função das doses de radiação ionizante, tanto do silicone como do mastic em maior detalhes amostra por amostra.

Nas Tabelas 7, 8, 9 e 10 são apresentados o comportamento das tensões de cisalhamento do silicone e do mastic sem e com radiação ionizante. No ambiente sobre radiação ionizante o mastic apresenta uma elevação acentuada nos resultados, enquanto o silicone seus valores diminui consideravelmente. 


\section{TENSÃO DE CISALHAMENTO em função da dose de radiação amostra 1}

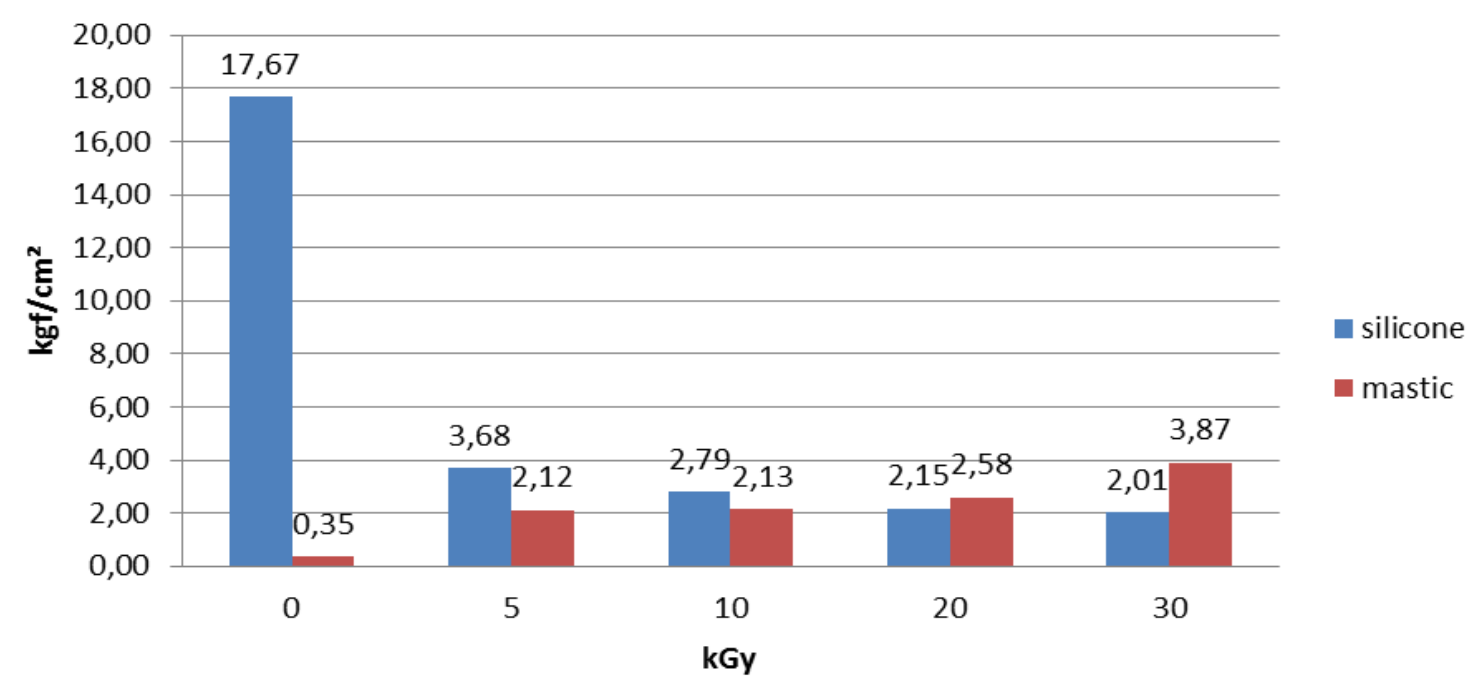

Figura 41: Tensão de cisalhamanto em função da radiação, amostra 1
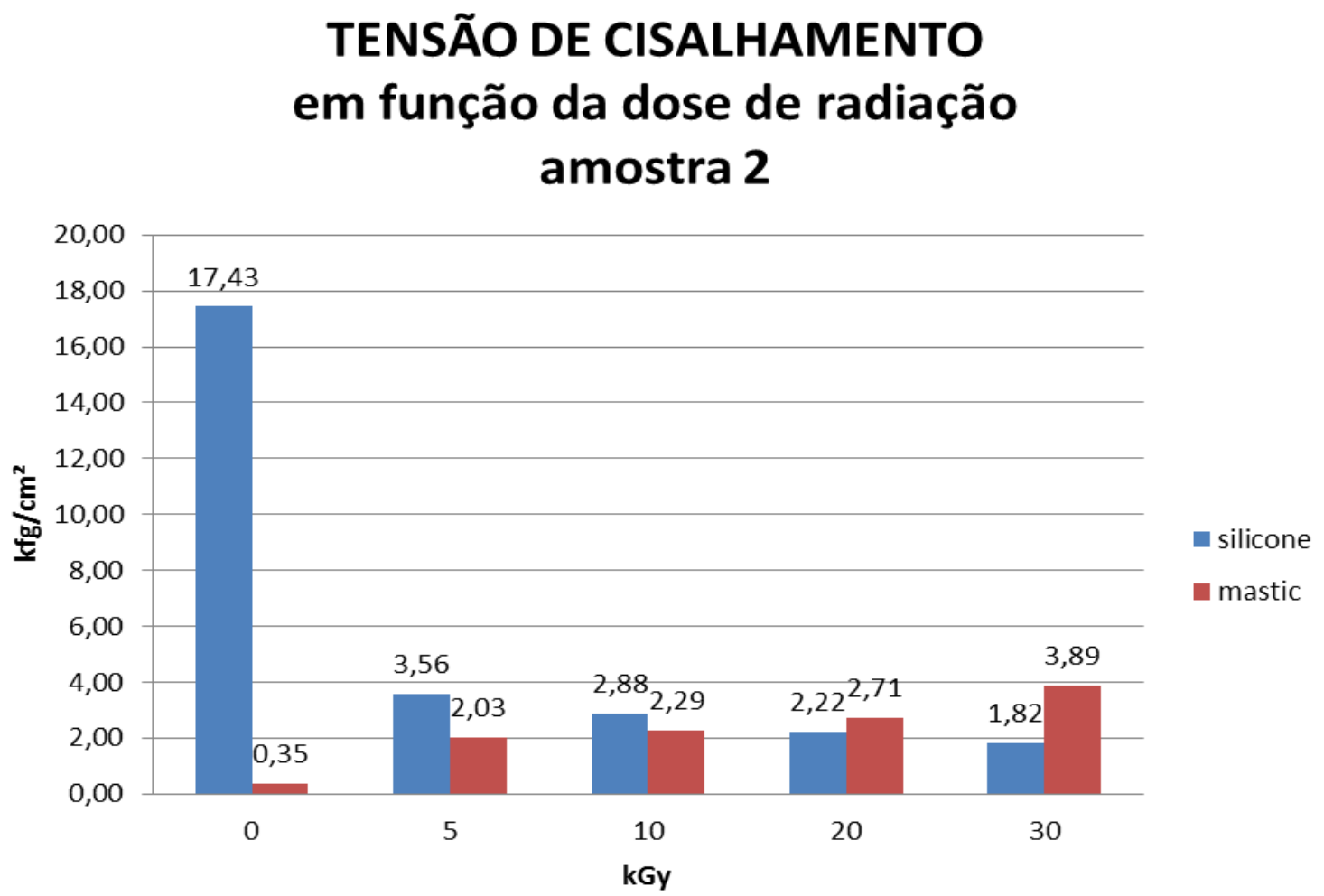

Figura 42: Tensão de cisalhamanto em função da radiação, amostra 2 


\section{TENSÃO DE CISALHAMENTO em função da dose de radiação amostra 3}

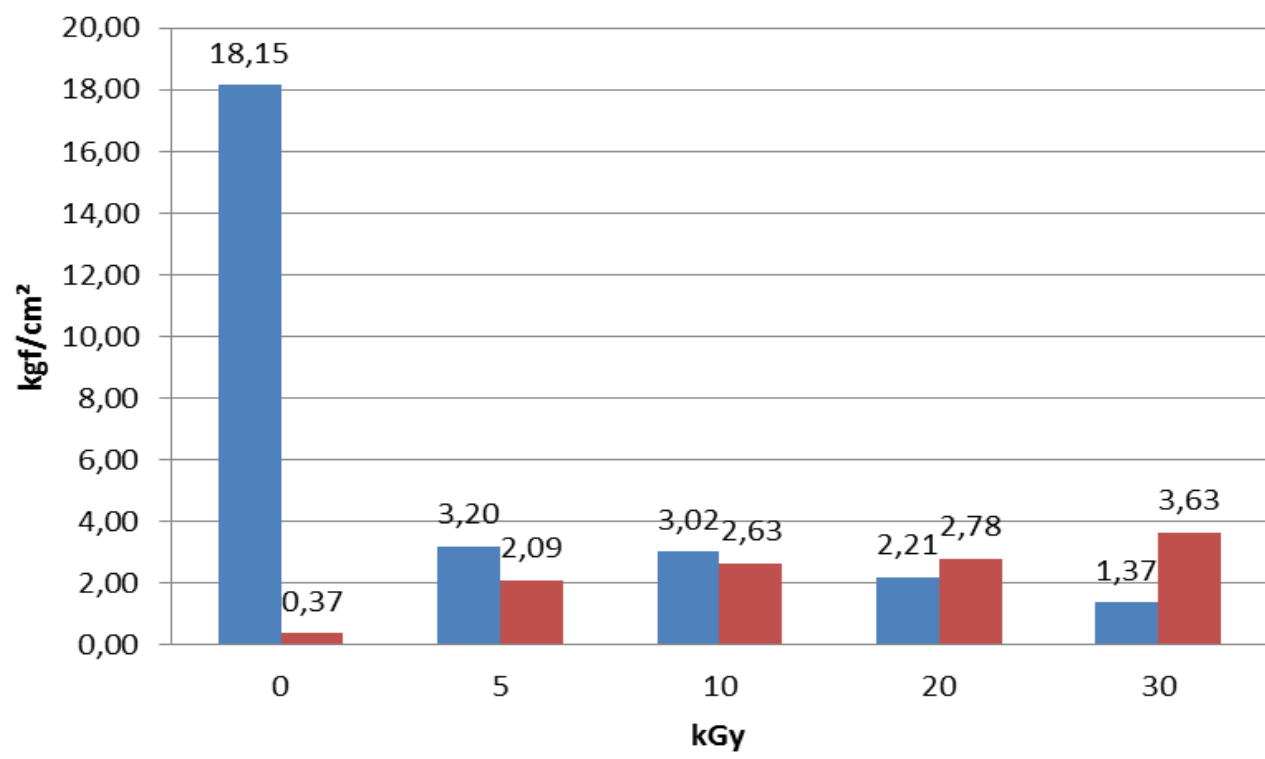

Figura 43: Tensão de cisalhamanto em função da radiação, amostra 3

\section{TENSÃO DE CISALHAMENTO em função da dose de radiação amostra 4}

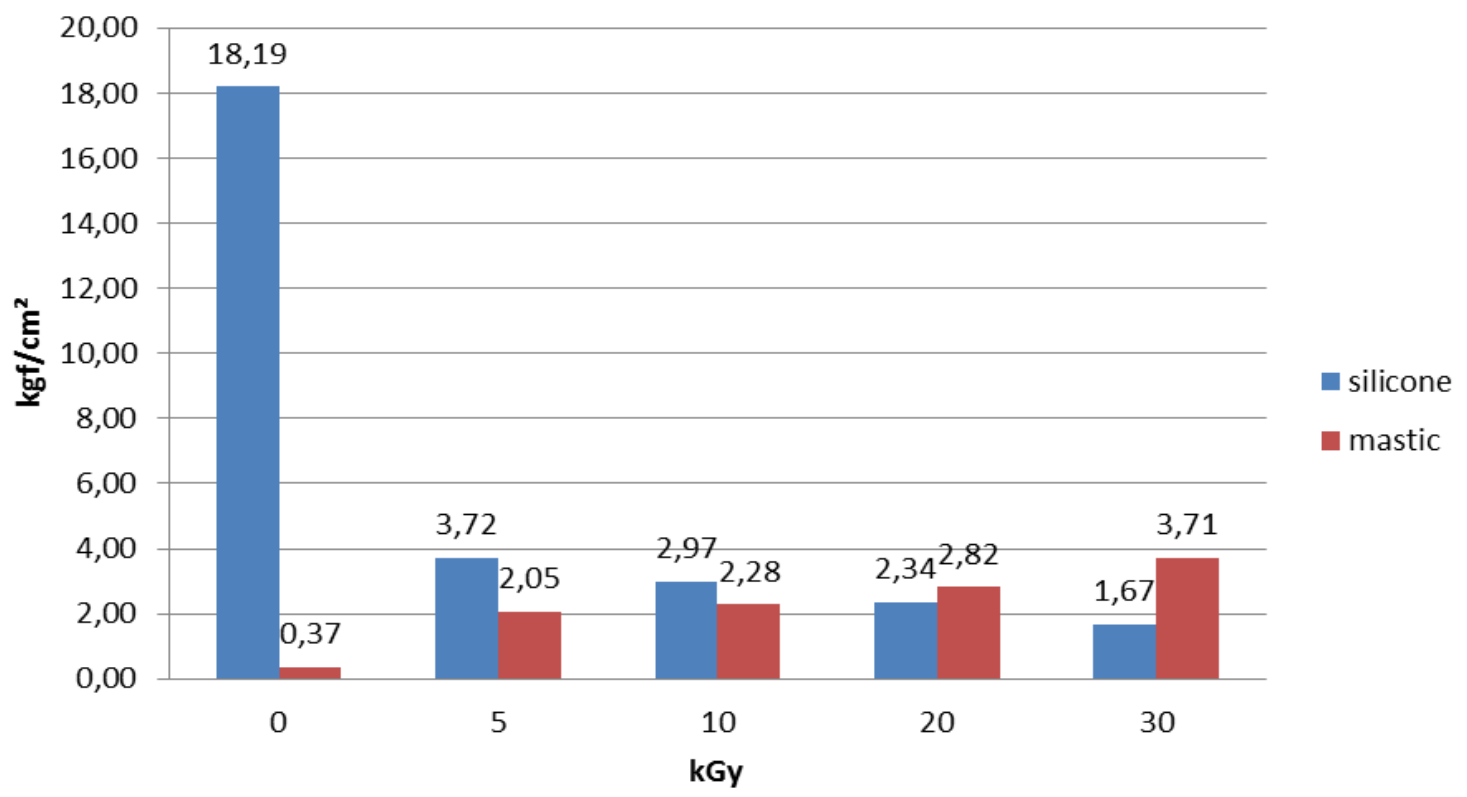

Figura 44: Tensão de cisalhamanto em função da radiação, amostra 4 


\section{TENSÃO DE CISALHAMENTO em função da dose de radiação amostra 5}

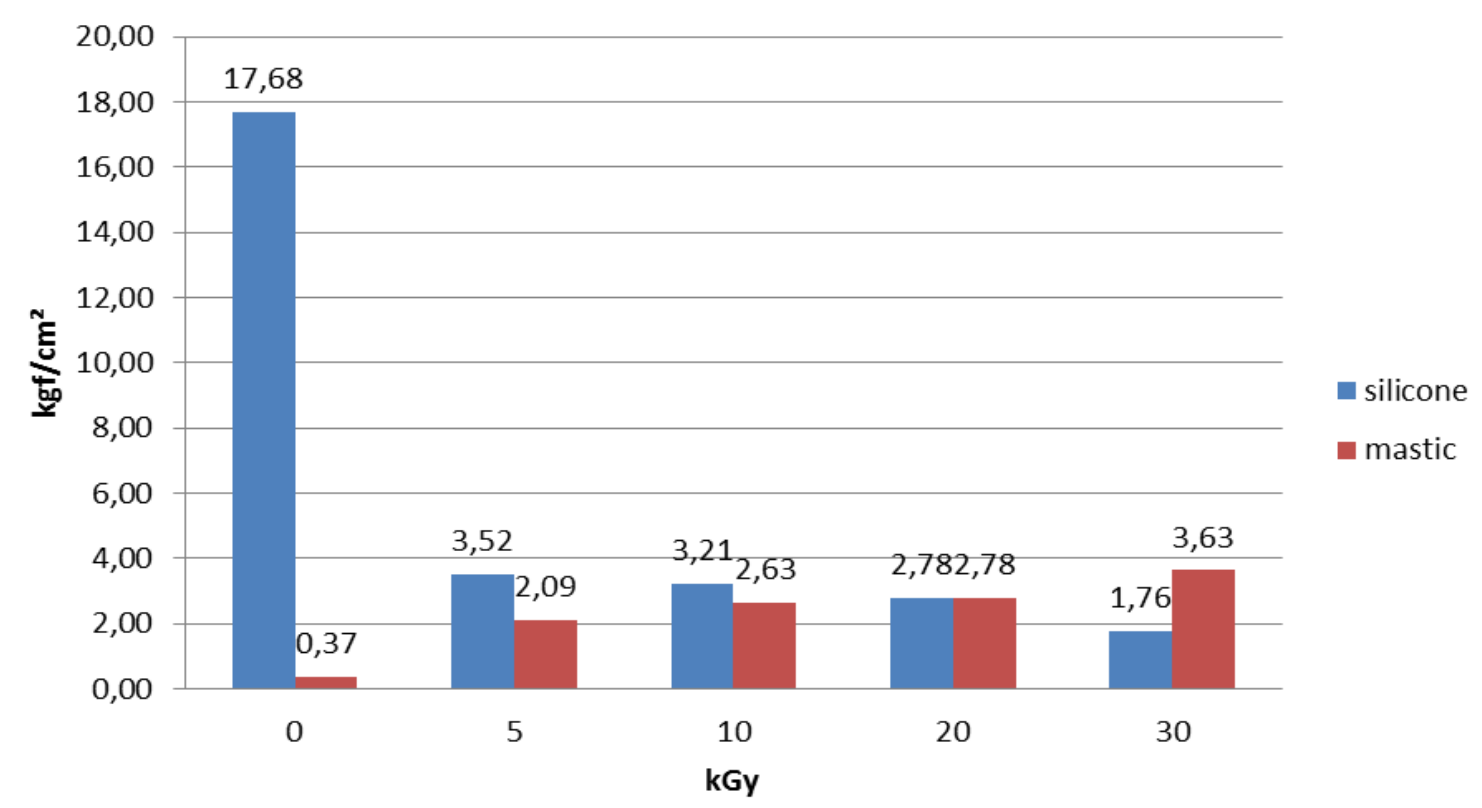

Figura 45: Tensão de cisalhamanto em função da radiação, amostra 5
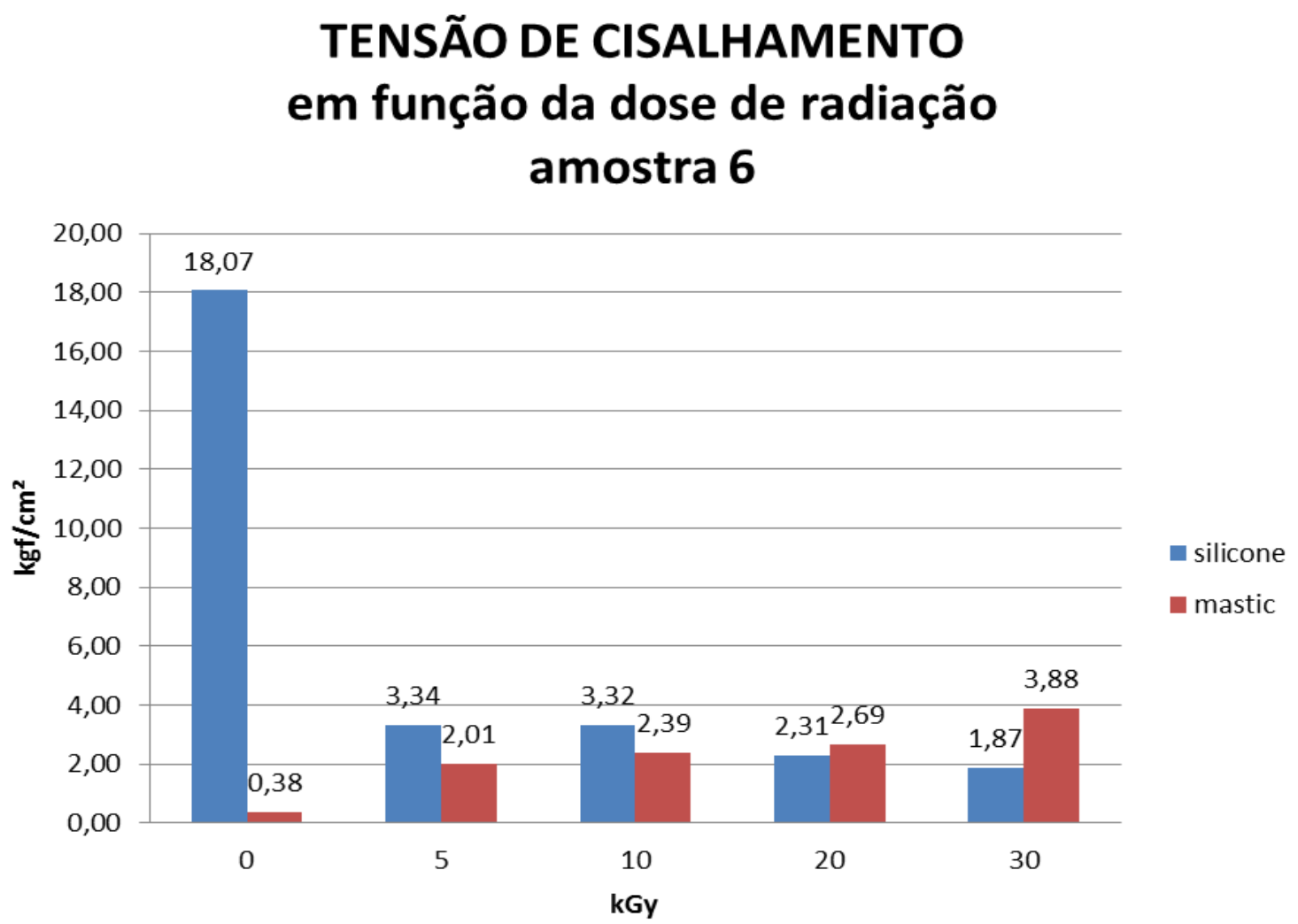

Figura 46: Tensão de cisalhamanto em função da radiação, amostra 6 


\section{TENSÃO DE CISALHAMENTO em função da dose de radiação amostra 7}

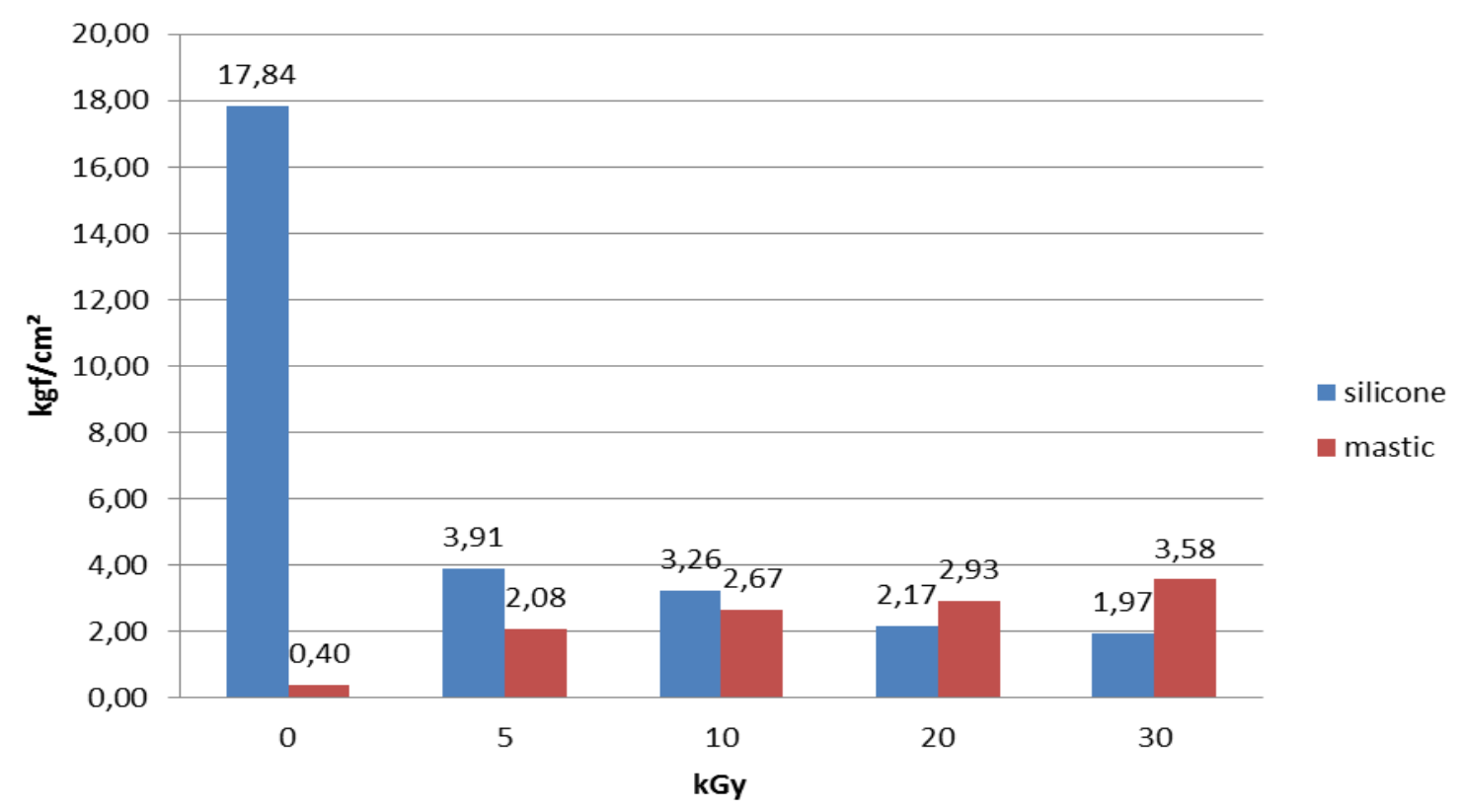

Figura 47: Tensão de cisalhamanto em função da radiação, amostra 7

\section{TENSÃO DE CISALHAMENTO em função da dose de radiação amostra 8}

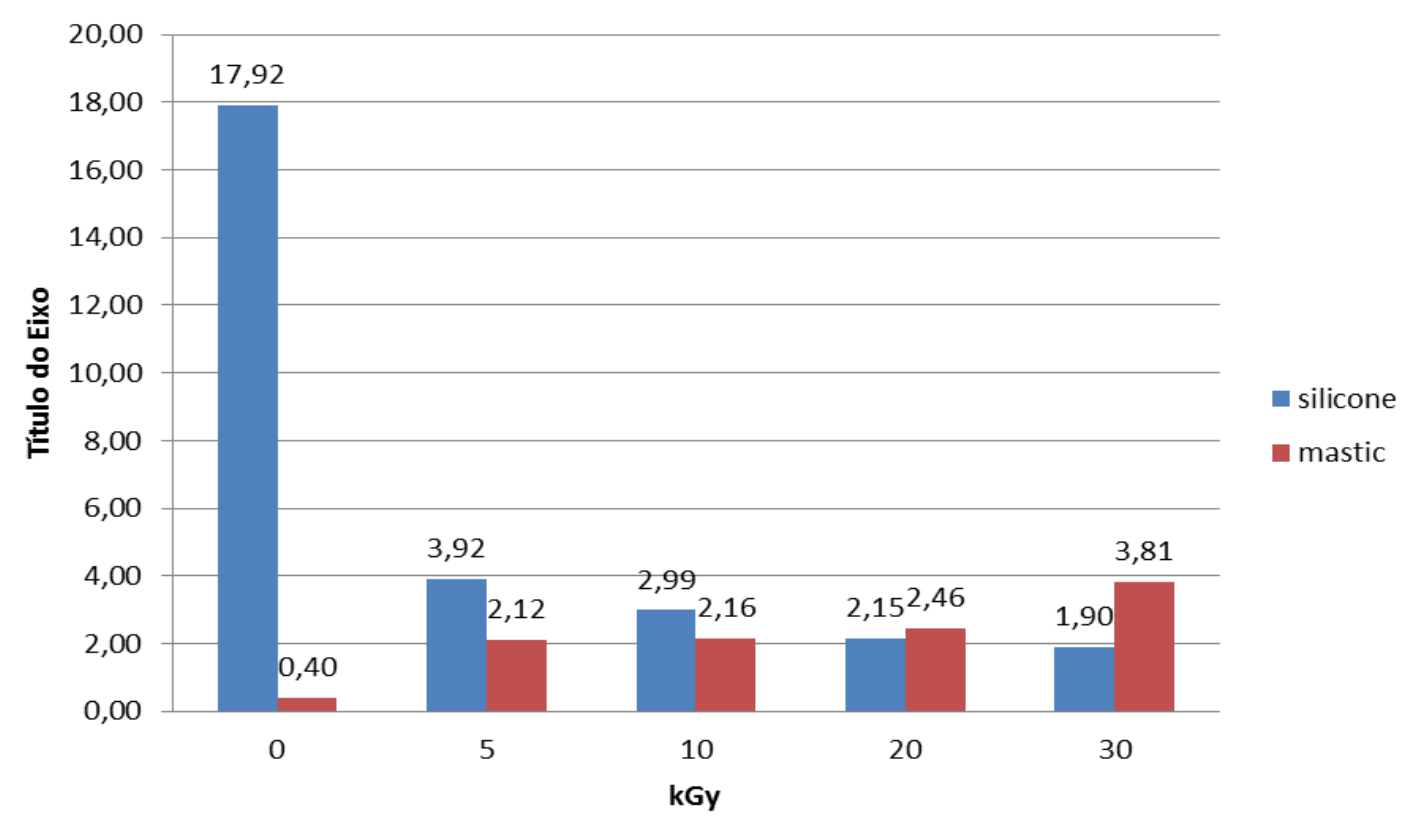

Figura 48: Tensão de cisalhamanto em função da radiação, amostra 8 


\section{TENSÃO DE CISALHAMENTO \\ em função da dose de radiação amostra 9}

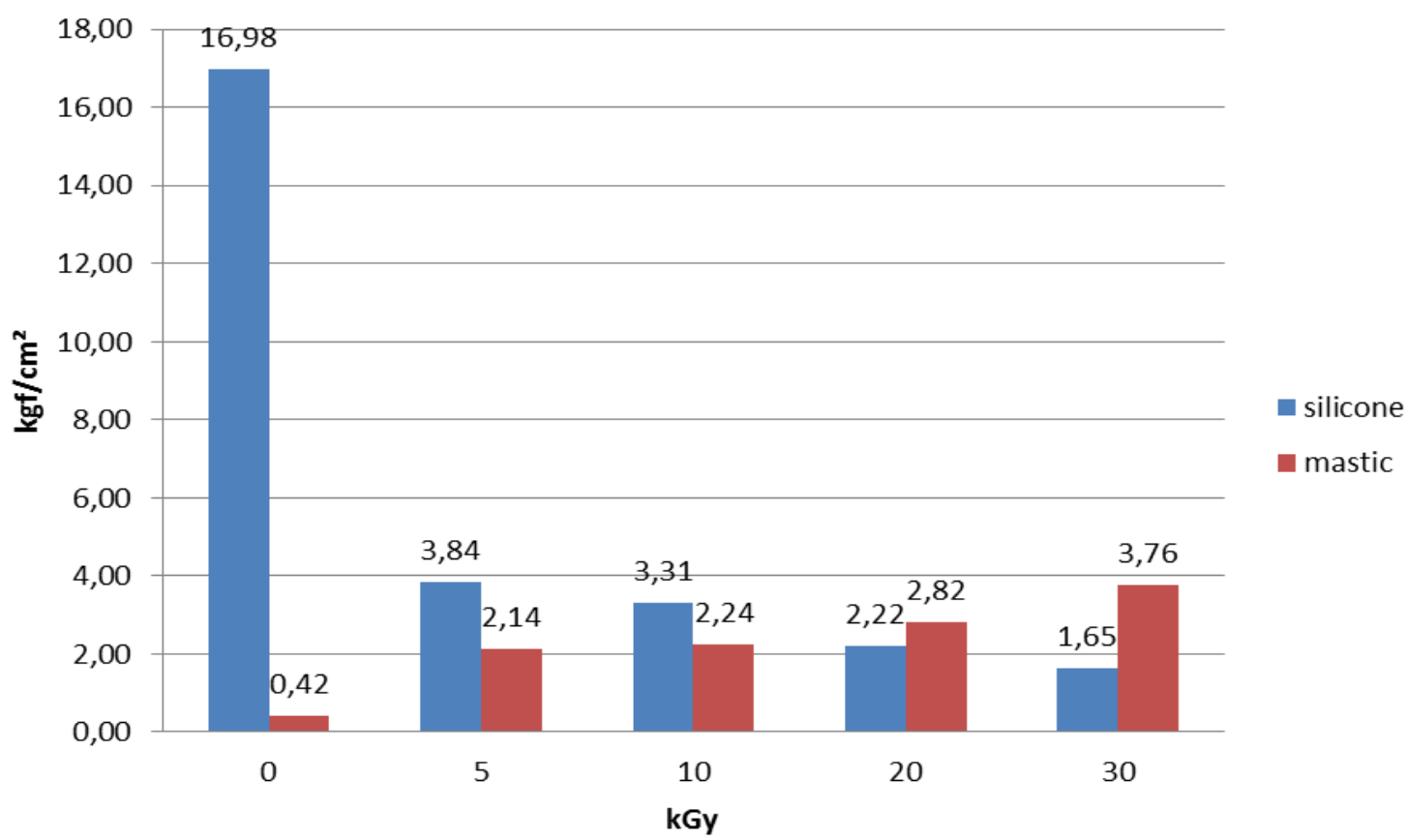

Figura 49: Tensão de cisalhamanto em função da radiação, amostra 9
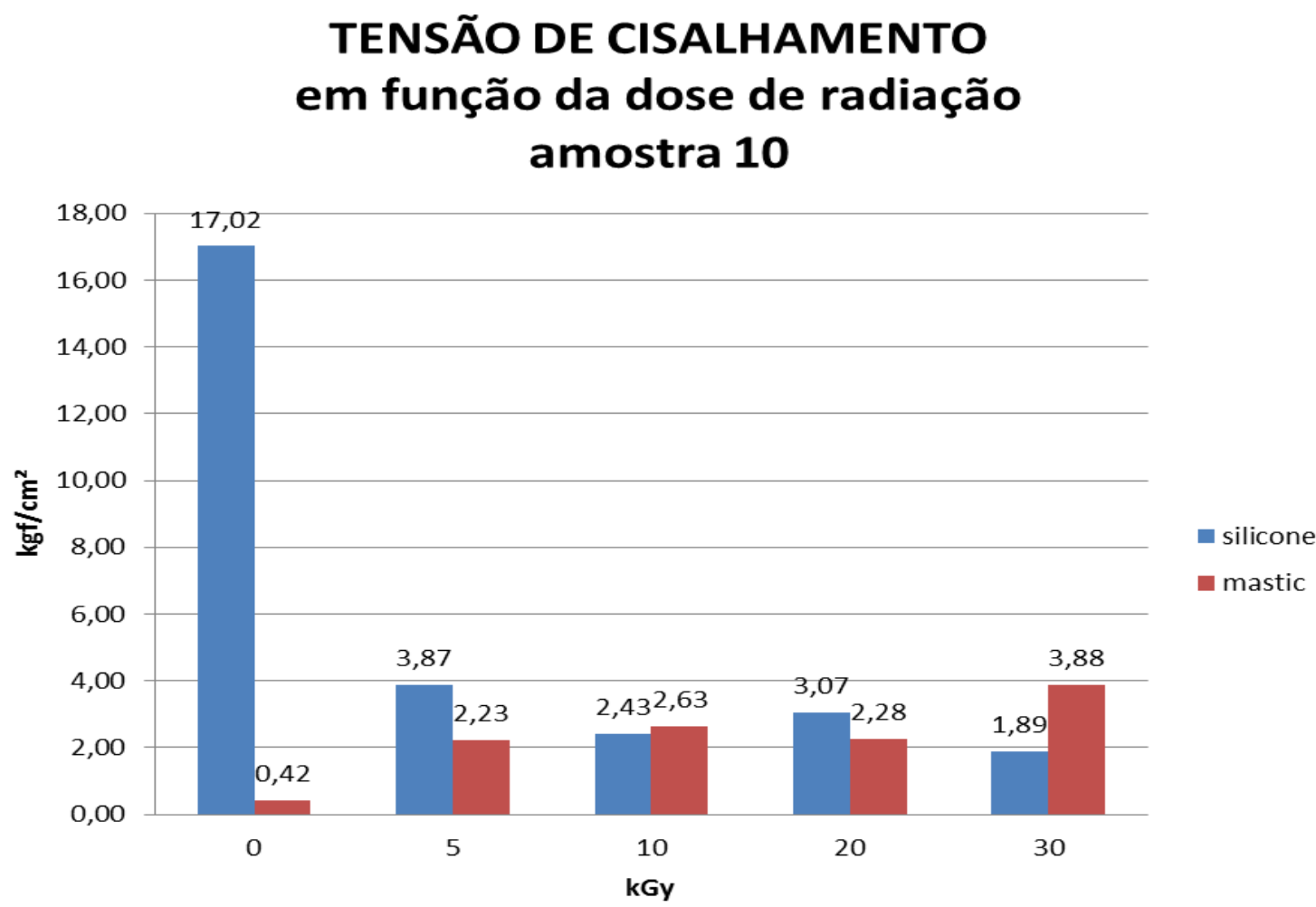

Figura 50: Tensão de cisalhamanto em função da radiação, amostra 10 
Tabela 7: Tensão de cisalhamento do silicone sem radiação ionizante em função do tempo

Força máxima $\left(\mathrm{kgf} / \mathrm{cm}^{2}\right)$

\begin{tabular}{ccccccccccccc}
\hline amostras & 1 & 2 & 3 & 4 & 5 & 6 & 7 & 8 & 9 & 10 & média & desvio padrão \\
\hline dias & & & & & & & & & & & & \\
7 & 7,14 & 8,06 & 8,10 & 8,29 & 8,77 & 8,93 & 9,02 & 9,31 & 10,98 & 11,84 & 9,04 & 1,41 \\
14 & 8,00 & 10,46 & 11,97 & 12,67 & 12,99 & 13,22 & 13,38 & 13,57 & 13,92 & 13,61 & 12,38 & 1,84 \\
28 & 17,67 & 17,43 & 18,15 & 18,19 & 17,68 & 18,07 & 17,84 & 17,92 & 16,98 & 17,02 & 17,70 & 0,43 \\
\hline
\end{tabular}

Tabela 8: Tensão de cisalhamento mastic sem radiação ionizante em função do tempo

\begin{tabular}{ccccccccccccc}
\multicolumn{11}{c}{ Força máxima $\left(\mathrm{kgf} / \mathrm{cm}^{2}\right)$} \\
\hline amostras & 1 & 2 & 3 & 4 & 5 & 6 & 7 & 8 & 9 & 10 & média desvio padrão \\
\hline dias & 1 & & & & & & & & & & & \\
7 & 0,16 & 0,18 & 0,18 & 0,18 & 0,18 & 0,18 & 0,19 & 0,19 & 0,22 & 0,24 & 0,19 & 0,02 \\
14 & 0,18 & 0,21 & 0,22 & 0,24 & 0,26 & 0,26 & 0,27 & 0,30 & 0,30 & 0,32 & 0,26 & 0,04 \\
28 & 0,35 & 0,35 & 0,37 & 0,37 & 0,38 & 0,38 & 0,40 & 0,40 & 0,42 & 0,42 & 0,38 & 0,03 \\
\hline
\end{tabular}

Tabela 9: Tensão de cisalhamento silicone com radiação ionizante em função da dose

Força máxima $\left(\mathrm{kgf} / \mathrm{cm}^{2}\right)$

\begin{tabular}{ccccccccccccc}
\hline amostras & 1 & 2 & 3 & 4 & 5 & 6 & 7 & 8 & 9 & 10 & média & desvio padrão \\
\hline $\begin{array}{c}\text { Radiação (kGy) } \\
0\end{array}$ & 17,67 & 17,43 & 18,15 & 18,19 & 17,68 & 18,07 & 17,84 & 17,92 & 16,98 & 17,02 & 17,70 & 0,41 \\
& & & & & & & & & & & & \\
5 & 3,68 & 3,56 & 3,20 & 3,72 & 3,52 & 3,34 & 3,91 & 3,92 & 3,84 & 3,87 & 3,66 & 0,24 \\
10 & 2,79 & 2,88 & 3,02 & 2,97 & 3,21 & 3,32 & 3,26 & 2,99 & 3,31 & 2,43 & 3,02 & 0,26 \\
20 & 2,15 & 2,22 & 2,21 & 2,34 & 2,78 & 2,31 & 2,17 & 2,15 & 2,22 & 3,07 & 2,36 & 0,29 \\
30 & 2,01 & 1,82 & 1,37 & 1,67 & 1,76 & 1,87 & 1,97 & 1,90 & 1,65 & 1,89 & 1,79 & 0,18 \\
& & & & & & & & & & & & \\
\hline
\end{tabular}


Tabela 10: Tensão de cisalhamento mastic com radiação ionizante em função da dose

Força máxima (kgf/cm²)

\begin{tabular}{ccccccccccccc}
\hline amostras & 1 & 2 & 3 & 4 & 5 & 6 & 7 & 8 & 9 & 10 & média & desvio padrão \\
\hline $\begin{array}{c}\text { Radiação (kGy) } \\
0\end{array}$ & 0,35 & 0,35 & 0,37 & 0,37 & 0,38 & 0,38 & 0,40 & 0,40 & 0,42 & 0,42 & 0,38 & 0,02 \\
& & & & & & & & & & & & \\
5 & 2,12 & 2,03 & 2,09 & 2,05 & 2,01 & 2,01 & 2,08 & 2,12 & 2,14 & 2,23 & 2,09 & 0,06 \\
10 & 2,13 & 2,29 & 2,63 & 2,28 & 2,39 & 2,34 & 2,67 & 2,16 & 2,24 & 2,63 & 2,38 & 0,19 \\
20 & 2,58 & 2,71 & 2,78 & 2,82 & 2,69 & 2,90 & 2,93 & 2,46 & 2,82 & 2,28 & 2,70 & 0,19 \\
30 & 3,87 & 3,89 & 3,63 & 3,71 & 3,88 & 3,53 & 3,58 & 3,81 & 3,76 & 3,88 & 3,75 & 0,13 \\
\hline
\end{tabular}

Nos resultados apresentados na Tabela 7 e mostrados na Figura 37 podemos observar a evolução da tensão de cisalhamento ao longo do tempo, isto demonstra claramente que as quantidades de ligações cruzadas que estão ocorrendo no sistema silicone, isto é, a cura esta ocorrendo lentamente e evoluindo, esta evolução esta relacionada com a elevação das forças de coesão, justificando assim o processo de cura do silicone. Entretanto este mesmo tipo de comportamento não é observado no mastic na Tabela 8 e mostrado na Figura 38 , os valores encontrados são baixos em relação ao silicone. Os valores encontrados no mastic estão relacionados à evaporação de solventes presentes em sua formulação e não a um processo de cura como ocorre com o silicone. Quando as amostras de silicone são expostas a radiação ionizante o comportamento inverte, isto é, as tensões de cisalhamento do silicone caem enquanto as do mastic sobem, como apresentados nas Tabelas 9 e 10 respectivamente e mostrados nas Figuras 39 e 40 . No caso do mastic houve uma reticulação do polímero butil (Figura 51) na presença da radiação ionizante.

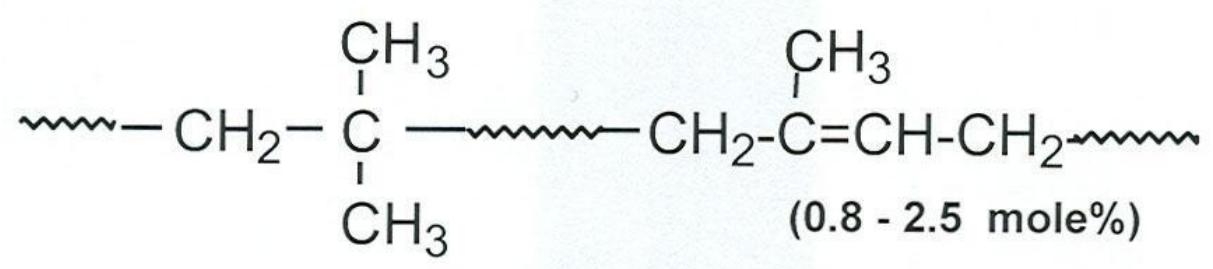

Figura 51 - Estrutura do polímero butil 
A Figura 52 mostra os espectros FTIR de amostras de silicone antes e após a irradiação com feixe de elétrons.

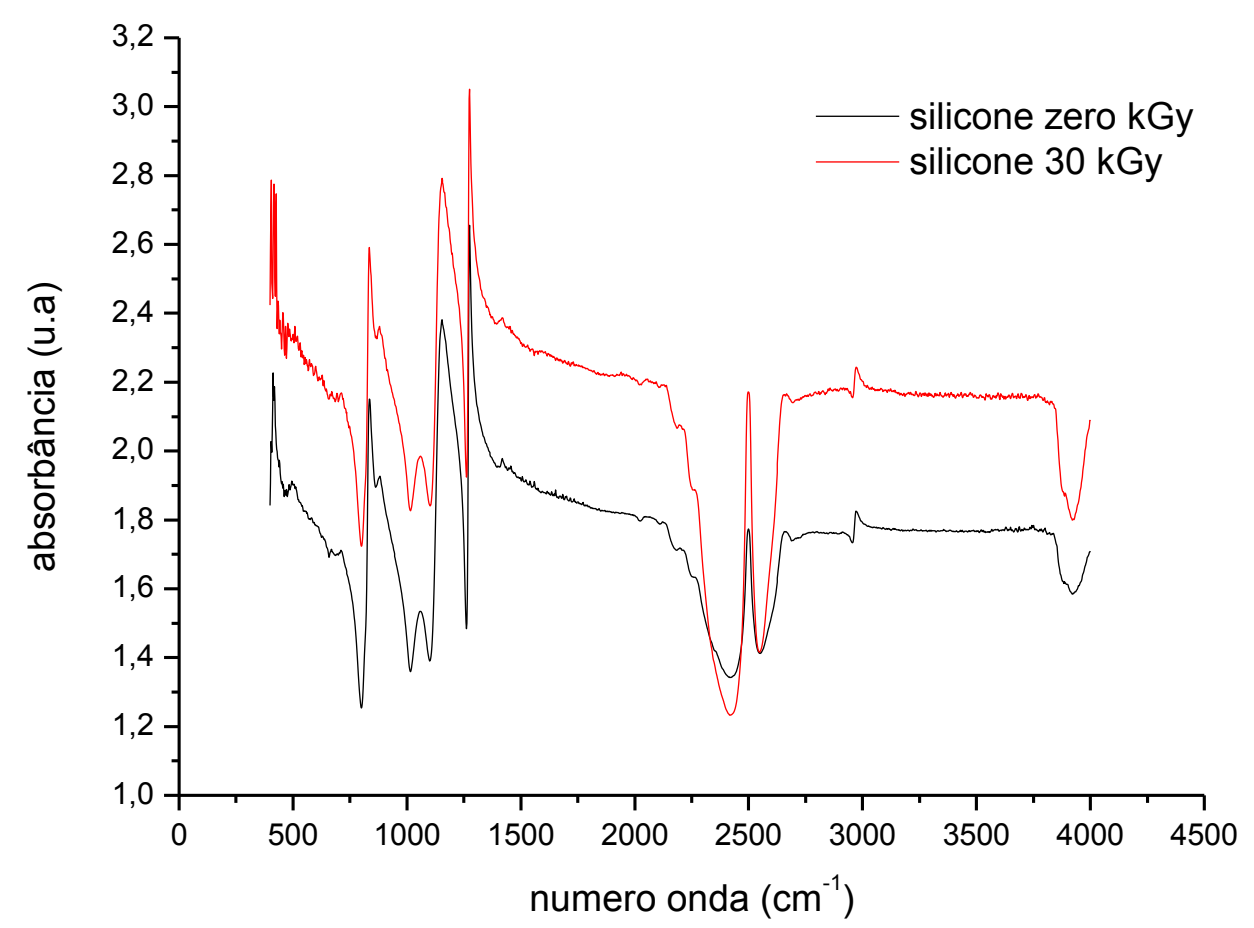

Figura 52 - Espectros de FTIR do silicone antes e após irradiação com feixe de elétrons 30 kGy

Na Figura 52 as bandas que aparecem em 2960 e $1258 \mathrm{~cm}^{-1}$ são atribuídas às vibrações da ligação $\mathrm{C}-\mathrm{H}$ e $\mathrm{Si}-\mathrm{CH}_{3}$, respectivamente, que envolvem os grupos laterais $\mathrm{CH}_{3}$. As bandas localizadas na faixa de 2908 a $2960 \mathrm{~cm}^{-1}$ correspondem ao estiramento assimétrico dos grupos funcionais $\mathrm{CH}-\mathrm{CH}_{3}$. Já as vibrações correspondentes ao estiramento simétrico e assimétricos dos grupos $\mathrm{CH}_{2}$ e $\mathrm{CH}_{3}$ estão na faixa de 1375 a $1465 \mathrm{~cm}^{-1}$. As vibrações correspondentes aos grupos de silício $\mathrm{Si}-\mathrm{CH}_{3}$ aparecem numa faixa muito estreita entre 1256 a $1259 \mathrm{~cm}^{-1}$. As vibrações dos grupos que compõe a estrutura principal do silicone aqui estudado, Si-O-Si, esta na faixa de 1015 a $1098 \mathrm{~cm}^{-1}$. Nas extremidades das cadeias polimérica aparecem os grupos $\mathrm{Si}\left(\mathrm{CH}_{3}\right)_{3}$ cujas vibrações estão na faixa de 850 a 870. Na faixa de 740 a $840 \mathrm{~cm}^{-1}$ são observadas as vibrações dos grupos $\mathrm{Si}\left(\mathrm{CH}_{3}\right)_{2}$. $\mathrm{Na}$ faixa de 690 a $700 \mathrm{~cm}^{-1}$ observa-se vibrações correspondentes ao grupo $\mathrm{Si}\left(\mathrm{CH}_{3}\right)_{3}$ (Silverstein, et al. 1979). Em relação aos efeitos da radiação ionizante observa-se alterações no espectro FTIR apenas na região de 2300 a 
$2800 \mathrm{~cm}^{-1}$ que corresponde a vibrações das ligações $C \equiv C$ formadas durante 0 processo de cura do principal componente da formulação do silicone, o dimetil siloxano hidroxi terminado. Observa-se que a banda centrada em $2500 \mathrm{~cm}^{-1}$ tem sua intensidade em absorbância praticamente dobrada após a irradiação. Portanto, infere-se que 0 número deste tipo de ligação eleva-se consideravelmente em relação à amostra de silicone sem o efeito da radiação ionizante. Este número pode estar relacionado com um rearranjo dentro da estrutura do silicone. Este rearranjo com certeza desestabilizou a estrutura do silicone. A queda nas tensões de cisalhamento do silicone ocorreu de forma acentuada, uma formação excessiva deste tipo de ligação compromete as ligações de adesão na superfície do material (alumínio) como mostrado na Figura 39.

A Figura 53 mostra os espectros FTIR de amostras de mastic antes e após a irradiação com feixe de elétrons.

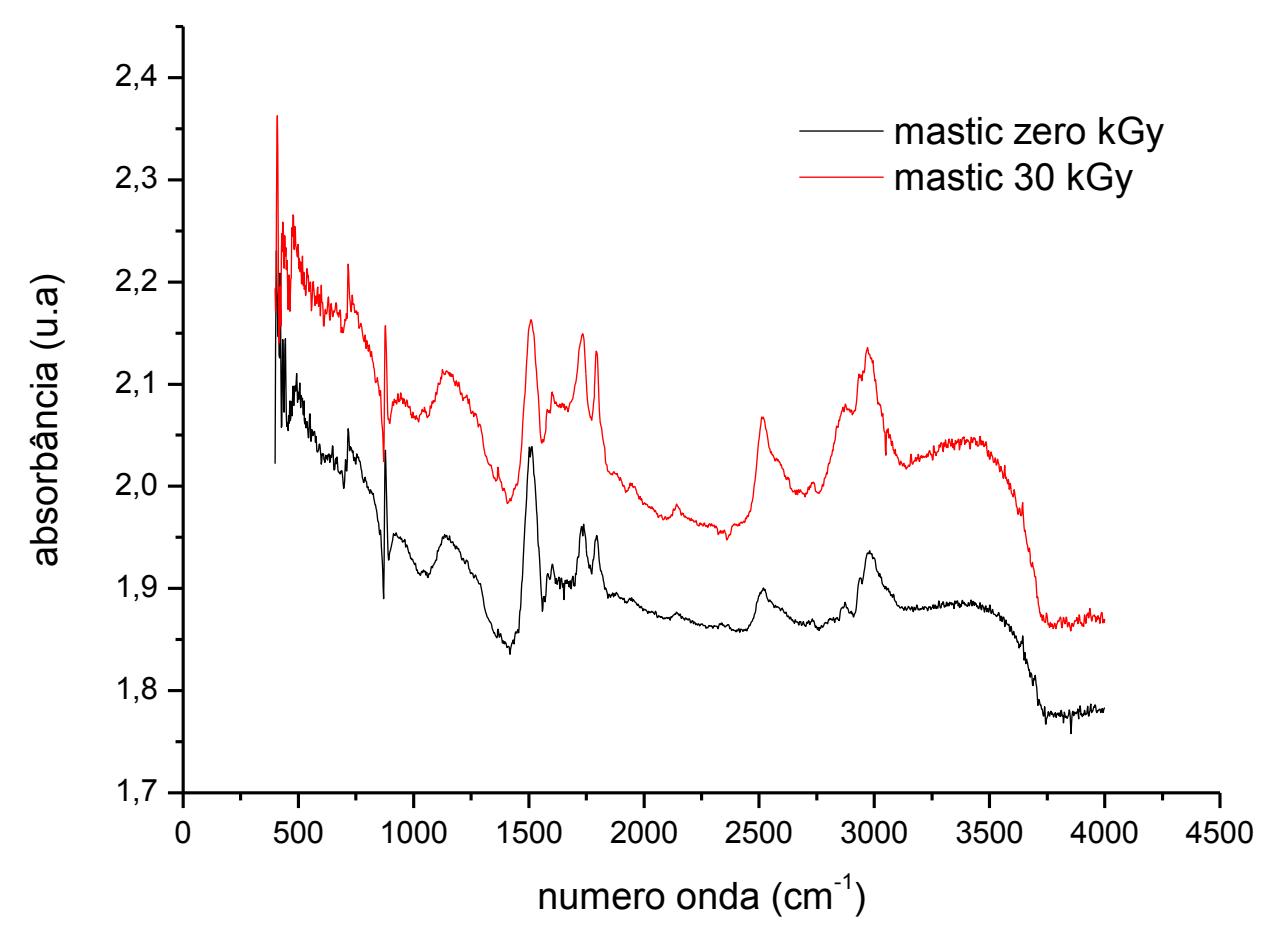

Figura 53 - Espectros de FTIR do mastic antes e após irradiação com feixe de eletrons $30 \mathrm{kGy}$ 
$\mathrm{Na}$ Figura 53 apresenta as bandas de abssorbância na faixa de 1500 a $2000 \mathrm{~cm}^{-1}$ são atribuídas às vibrações da ligação $\mathrm{C}=\mathrm{C}$, que após a radiação ionizante apresentam intensidades superiores em relação a amostra de mastic sem a radiação. Na faixa de 2500 a $3000 \mathrm{~cm}^{-1}$ as bandas de absorbância são atribuídas às vibrações das ligações de $\mathrm{C}-\mathrm{H} ;=\mathrm{C}-\mathrm{H}$; O-H (Silverstein, et al. 1979), que após a radiação ionizante tiveram um rearranjo que promoveu um aumento na tensão de cisalhamento como mostrado no Figura 40. 


\section{CONCLUSÕES}

Os resultados do presente trabalho explicam e comprovam como se comportam as forças de adesão do silicone e do mastic, tanto em condições ambiente como sob o efeito de radiação ionizante. Nos ensaios realizados constatou-se que o silicone tem uma adesão superior ao mastic em condições ambiente, entanto o mastic sob o efeito da radição ionizante apresentou resultados superiores em relação à sua condição sem a presença da radiação.

No ensaio de alongamento só foi possível a realização com a amostra de silicone, pois a do mastic não apresentou condições necessárias para este ensaio.

No ensaio de grau de reticulação foi importante demonstrar qual produto foi capaz de atingir o estado de cura em função dos ciclos predeterminados neste trabalho. O silicone apresentou um grau de reticulação, após 28 dias, de 74,16\%, isto é, atingiu o estado de gel (cura). No mastic, o valor correspondente, no mesmo prazo, foi de $48,32 \%$. Este número foi indicado como resíduo de compostos minerais e não a formação do estado de gel como ocorrido no silicone.

Em relação ao mastic verificam-se picos exotérmicos na faixa de 230 a $280^{\circ} \mathrm{C}$, quando realizado o ensaio de calorimetria exploratória diferencial (DSC), enquanto o silicone não apresenta este tipo de evento. No ensaio do mastic existe uma pequena indicação de cura que está relacionada com a quantidade de polibuteno que está contida na formulação. Tanto o silicone como o mastic não apresentaram nenhuma alteração com relação à análise térmica mesmo após serem submetidos à radiação ionizante.

Quando as amostras são submetidas à radiação ionizante o silicone degrada e suas forças de adesão são inferiores em relação ao ensaio de cisalhamento sem a presença da radiação ionizante. Com o mastic ocorre um comportamento inverso, as forças de adesão apresentam resultados superiores comparados com aqueles sem a presença da radiação ionizante. Este fato está relacionado com as ligações cruzadas que a radiação ionizante pode ter facilitado.

No ensaio de espectroscopia infravermelha por transformada de Fourier (FTIR) o silicone apresenta uma queda na banda centrada em $2500 \mathrm{~cm}^{-1}$, tem sua intensidade em absorbância praticamente dobrada após a irradiação. Portanto, infere-se que o número deste tipo de ligação eleva consideravelmente o efeito na 
queda das forças de adesão. Este número pode estar relacionado com um rearranjo dentro da estrutura do silicone que acabou desestabilizando o produto. A queda nas tensões de cisalhamento do silicone ocorreu de forma acentuada, uma formação excessiva deste tipo de ligação compromete as ligações de adesão na superfície do substrato.

No mastic as bandas de absorbância na faixa de 1500 a $2000 \mathrm{~cm}^{-1}$ apresentaram vibrações da ligação $C=C$, que após a radiação ionizante apresentam intensidades superiores em relação à amostra de mastic sem a radiação. E na faixa de 2500 a $3000 \mathrm{~cm}^{-1}$, as bandas de absorbância apresentaram vibrações das ligações de $\mathrm{C}-\mathrm{H} ;=\mathrm{C}-\mathrm{H} ; \mathrm{O}-\mathrm{H}$ elevadas, quando comparadas com a ausência da radiação ionizante. Este rearranjo promoveu um aumento na tensão de cisalhamento do mastic.

No ensaio das tensões de cisalhamento foi possível constatar a queda acentuada de 9,88 vezes inferior (em média) comparada com as tensões com presença da radiação ionizante na amostra de silicone, evidenciando a sua degradação, enquanto o mastic apresentou um ganho significativo nas tensões de cisalhamento na ordem de 9,86 vezes superior com a presença da radiação ionizante.

A radiação ionizante possibilitou ao mastic elevar suas tensões de cisalhamanto, que é uma excelente contribuição para a área de adesivos, uma vez que seu custo é baixo em relação aos outros selantes. Uma excelente possibilidade de prospecção de um novo mercado de negócios para ambientes onde é necessário uma colagem ou vedação com selantes. 


\section{SUGESTÕES PARA TRABALHOS FUTUROS}

- Levantamento de novas referências sobre o silicone e mastic em ambientes com radiação ionizante.

- Análises das estruturas tanto do silicone como do mastic em condições com e sem radiação ionizante.

- Estudo de novos adesivos para ambientes com radiação ionizante baseados em mastic devido ao seu baixo custo por quilo em relação ao silicone.

- Submeter estes produtos a outras fontes de energia, como por exemplo: elétrica, eletromagnéticas, magnéticas entre outras. 


\section{REFERÊNCIAS}

ABIQUIM-ASSOCIAÇÃO BRASILEIRA DA INDUSTRIA QUÍMICA. Estatística do segmento de colas, adesivos e selantes. Abiquim-Equipe de economia e estatística, São Paulo, v. 10, n. 1, 19p, 2011.

AHAGON, A.; GENT, A.N. J. Polym. Sci. Polym. Phys. Ed. 13, p. 1285, 1975

ALINGER, N. L.; CAVA, M. P.; DE JONGH, D. C.; JOHNSON, C. R.; LEBEL, N. A.; STEVENS, C. L.; Química Orgânica - 2. ${ }^{a}$ Edição; Editora Guanabara-Koogan S. A.; Rio de Janeiro - Brasil; p.183-194, 1976

AMELINCKX, S.; VAN DYCK, D. Constitutional vacancies: ordering. In: BEVER, Michael B. (Ed.). Encyclopedia of materials science and engineering. Oxford: Pergamon, v. 1, p. 77-84, 1986

AMERICAN SOCIETY FOR TESTING AND MATERIALS. ASTM D 412: Vulcanized Rubber and Thermoplastic Elastomers - Tension. PensylvaniaUnited States, 1992.

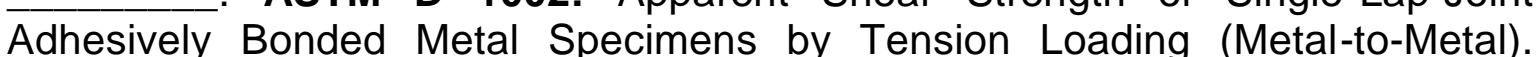
Pennsylvania - United States, 2001.

ASTM D 2765: Determination of Gel Content and Swell Ratio of Crosslinked Ethylene Plastics. Pennsylvania - United States, 1995.

ASTM D 3418: Transition Temperatures of Polymers by Thermal Analysis. Pennsylvania - United States, 1982.

ASH, M.; ASH, I. A formulary of adhesives and other sealants. Chemical. New York, USA, p.274, 1987.

ASSOCIAÇÃO BRASILEIRA DE NORMAS TÉCNICAS. NBR 9239: Adedivos Terminologia. Rio de Janeiro, 2011.

BEVER, B. M. Science and Engeneering. Encyclopedia of Materials. v.1, Cambridge, Massachusetts, USA, p. 82, 1986.

BIKERMAN, J. J. The Science of Adhesive Joints. Academic Press. New York, 1961

BODNAR, M. J. Structural Adhesives Bonding. Interscience Publishers. New Jersey, USA, p. 456-459, 1966.

p. 291-301, 1989.

BUONOCORE, M.G. Principles of adhesive retention and adhesive restorative materials. J. Amer. Dent. Ass. USA, v.67, n.9, p. 382-391, 1963 
CARBARY, L. D. Sealant Materials - Engineered Materials Handbook. ASM International Handbook Committee. v.3, section 3 - Metals Park, Brinson, Half, USA, p. 188-192, 1987

COUTINHO, M. Avaliação da adaptação à dentina de alguns agentes de proteção com ou sem sistema restaurados adesivos, em função de diferentes tratamentos da superfície dentinária, 2000. 182p Tese (doutorado) - Faculdade de Odontologia de Bauru, Universidade de São Paulo, São Paulo, 2000

DAMUSIS, A. Sealants. Reinhold. New York, USA, p. 92-115, 1967

DUNN, D. J. Sealant Materials. Engineered Materials Handbook. ASM International Handbook Committee. v.3, section 1, Metals Park, Brinson, Half USA. p. 48-55, 1987

ELVERS, B. et. al. Encyclopedia of industrial chemistry silicon compounds, inorganic to stains, microscopic. v. A24, New York, USA, p.76-81, 1993.

FLEISCHMANN, W., GARNICH, F., LENNOX, A., MAYER, W., COCCO, J., FORGACH, A.D., HEATON J.J., McNICKLE, J.A., NOLAN, D.A., O’REILLY, C., PERKINS, J.G. Loctite worldwide design handbook. Rocky Hill: Loctite North America, Connecticut, USA, 463p., 1997.

FLICK, E. W. Adhesive and sealant compound and their formulations. Noyes. New Jersey, USA, p. 334-347, 1978.

FLICK, E. W. Adhesive and sealant compound formulations. Noyes. New Jersey, USA, 2ed., p. 284-303, 1984.

FOX, H. W., ZISMAN, W. A. Relation of Equilibrium Contact Angle to Liquid and Solid Constitution. Journal of Colloid Science. 5, p. 514, 1950

FRANTA, I. Elastomers and rubber compounding materials. Elsevier. New York, USA, p. 250-273, 1989.

GOULD, R. F. Stabilization of Polymers and Stabilizer. ACS. Washington, USA, p. 95-109, 1968.

HARKINGS, W. D. Physical Chemistry of Surface Films. Reinhold Publishing. New York, 1952

HOGEN-ESCH, T., SMID, J. Recent Advances in Anionic Polymerization. Elsevier. New York, USA, p. 329-349, 1987.

HOUWINK, R.; SALOMON, G. Adhesion and adhesives. Elsevier. New York, USA, v.1, p.290-293; 316,317; 390-397, 1965.

JACKSON, B.S. Industrial Adhesives and Sealants. Ed. Gret Britain by Anchor Press. Hutchinson Benham, London, England, p. 193-194, 1976. 
KLOSOWSKI, J.M.; SMITH, S.B. Sealant Materials. Engineered Materials Handbook. ASM International Handbook Committee. Metals Park, Brinson, Half - USA, v.3, section 3, p.187, 1987.

LANDROCK, A. H.; BEACH, N. E. Commercial and government specifications and standards. In. HARPER, Charles A. (Ed.) Handbook of plastics and elastomers. New York McGraw-Hill, cap. 10, 1975.

LEE, H.; ORLOWSKI, J. Adhesive dental composite restoratives. Lee Pharmaceuticals. California, USA, 65p, 1973.

LIEBHAFSKI, H. A. Silicones under the monogram. John Wiley \& Sons. New York, USA, 381p., 1978.

MORTON, M. Rubber technology. Van Nostrand Reinhold. New York, USA, 3 ed., p.406-407, 1987.

NETO, J. M. M.; NETO, J. M. G. Cura de selante de silicone acompanhada por medidas elétricas "in situ". Revista de Física Aplicada e Instrumentação. Universidade Federal do Piauí. Teresina-Piauí, v.13, n. 4, dezembro 1998.

PANEK, J. R.; COOK, J. P. Constrution sealants and adhesives. John Wiley \& Sons. New York, USA, 2 ed., 348p., 1984.

PAYNE, H. F. Organic Coating Technology. Willey \& Sons. 2 ed., 1964.

PETRIE, E. W. Handbook of Adhesives and Sealants, McGraw-Hill, New York, 2 ed., 2007.

POCIUS, A. V. Adhesion and Adhesives Technology. Hanser Publishers. New York, p.131, 1977.

QUINI, J.G. Adesivos estruturais uretânicos aplicados a combinações de compósitos, plásticos e metais. 2011. 144p. Tese (doutorado) - Instituto de Pesquisas Energéticas e Nucleares - IPEN. São Paulo, 2011

RANNEY, M. W. Silicones. New Jersey, USA, v.1, 351 p., 1977.

SCHNEBERGER, G. L. Chemical Aspects of Adhesive Bonding, Part II: Physical Properties. Adhesives Age. March 1970

SEYMOUR, R. B.; CARRAHER, JR. C. E. Polymer Chemistry: An introduction. Marcel Dekker AG. New York, p.345-346, 1981.

SILVA, L. G. A. et. al. Análises térmicas, ensaios mecânicos de tração e determinação do grau de reticulação em amostras de silicone e mastic da empresa Brascola. IPEN, São Paulo, Brasil. (Relatório técnico especialmente realizado para Empresa Brascola), 16p. 2003. 
SILVERSTEIN, R.N.; BASSLER, G.C.; MORRILL, T.C. Identificação Espectrométrica de Compostos Orgânicos. Rio de Janeiro, Guanabara Koogan, 3 ed., 1979

SHARPE, L. H. Adhesives Technology - Engineered Materials Handbook. ASM International Handbook Committee. Metals Park, Brinson, Half, USA, v.3, section 1, 1987.

SHIELDS, J. Adhesives Handbook. Newnes-Butterworths. London, England, p.7-29; 201; 255-271, 1976

SKEIST, I. Handbook of Adhesives. Van Nostrand Reinhold. New York USA , 2 ed., p. $3-18,1977$.

. Handbook of Adhesives. Van Nostrand Reinhold. New York, USA, 3 ed., p. 522 - 535, 1990.

STEPEK, J.; DAOUST, H. Additives for Plastics. Springer-Verlag. New York, USA, p.84-90, 1983.

STEVENS, M. P. Polymer chemistry an introduction. Ed. Addison-Wesley Publishing Company. University of Hartford, USA, p. 334-338, 1975.

STOCK, E. Manual para la industria de lacas y pinturas. Reverté. Barcelona, Espanã, p. 102-104, 1962.

THELEN, E. La unión adhesiva. In: SKEIST, I. (Ed.) Manual de adhesivos. México: Compañia Editorial Continental. México, p. 43-56, 1966

VOYUTSKII, S.S. Autohesion And Adhesion of High Polymers. Interscience Publishers, John Wiley \& Sons, New York, p. 140, 1963

WAKE, W. C. Adhesion and the Formulation of Adhesives. Appliend Science. Ripple Road ,Barking, Essex, England, p.232-233, 1976.

WU, S. Polymer interface and Adhesion. Marcel Dekker. New York, USA, p. 410-420, 1982.

ZIZMAN, W. A. Relation of the equilibrium contact angle to liquid and solid constitution. Advances in chemistry series. American Chemical Society. Washington, USA, v.43, p. 1-51, 1964. 